


\section{National Llbrary
of Carada}

Canadian Theses Service

Ottawa, Canada

K1A ON4
Bibliothegue nationale

du Canada

Service des thèses canadiennes
NOTICE

The quality of this microform is heavily dependent upon the quality of the original thesis submitted for microfilming. Every effort has been made to ensure the highest quality of reproduction possible.

If pages are missing, contact the university which granted the degree.

Some pages may have indistinct print especially if the original pages were typed with a poor typewriter ribbon or if the university sent us an inferior photocopy.

Reproduction in full or in part of this microlorm is governed by the Canadian Copyright Act, R.S.C. 1970, C. C-30, and subsequent amendments.
AVIS

La qualité de cette microforme dépend grandement de la qualité de la thèse soumise au microfilmage. Nous avons tout tait pour assurer une qualité supérieure de reproduction.

S'il manque des pages, veuillez communiquer avec luniversité qui a conféré le grade.

La qualité d'impression de certaines pages peut laisser à désirer, suntout si les pages originales ont été dactylogra. phiées à l'aide d'un ruban usé ou si l'université nous a fait parvenir une photocopie de qualité inlérieure.

La reproduction, méme partielle, de cefte microforme est soumise à la Loi canadienne sur le droit d'auteur, SRC 1970, c. C-30, et ses amendements subséquents. 
The History of the Classical Guitar in Canada

by

Norma M. MacSween, BMusA

A thesis submitted to the Faculty of

Graduate Studies and Research in partial fulfillment

of the requirements for the degree of

Master of Arts

in Canadian Studies

Carleton University

OTTAWA, Ontario

April 1990

(C) 1990 Norma M. MacSween 
National Library

of Canada

Canadian Theses Service

Ottawa. Canada

KIA ON4
Bibliotheqque nationale

du Canada

Service des thèses canadiennes
The author has granted an irrevocable nonexclusive licence allowing the National Library of Canada to reproduce, loan, distribute or sell copies of his/her thesis by any means and in any form or format, making this thesis available to interested persons.

The author retains ownership of the copyright in his/her thesis. Neither the thesis nor substantial extracts from it may be printed or otherwise reproduced without his/her permission.
L'auteur a accordé une licence irrévocable et non exclusive permettant à la Bibliothèque nationale du Canada de reproduire, prêter. distribuer ou vendre des copies de sa these de quelque manière et sous quelque forme que ce soit pour mettre des exemplaires de cette thèse à la disposition des personnes intéressées.

L'auteur conserve la propriété du droit d'auteur qui protège sa thèse. Ni la thèse ni des extıaits substantiels de celle-ci ne doivent être imprimés ou autrement reproduits sans son autorisation. 
The undersigned recommend to the Faculty of Graduate Studies and Research acceptance of the thesis

"The History of the Classical Guitar in Canada"

submitted by Norma MacSween, B. Mus .

in partial fulfilment of the requirements for

the degree of Master of Arts

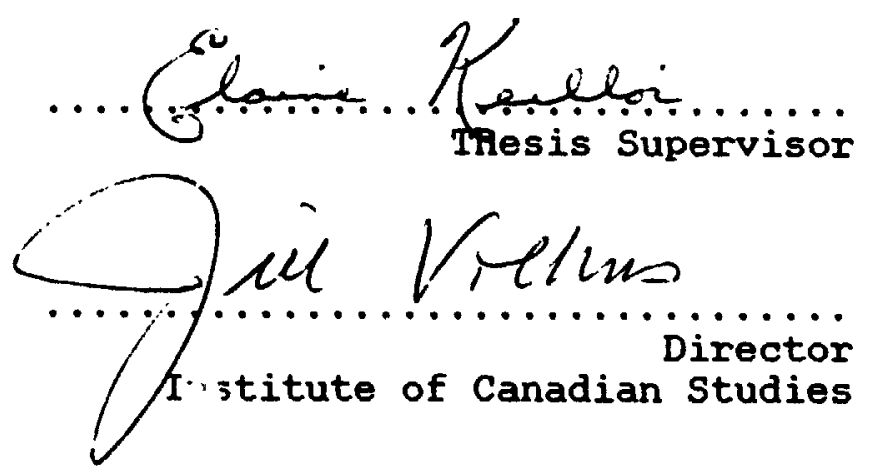

Carleton University

Ottawa, Ontario

May 1990 


\section{ABSTRACT}

This thesis explores the history of the classical guitar in Canada since the instrument was first brought to the country in the mid-seventeenth century. The first aspect of the study argues that the guitar was a popular instrument in Canada during the eighteenth and nineteenth centuries and demonstrates that, while from 1630 to 1850. the guitar in Canada was influenced by the European guitar. by the late nineteenth century influences were very much American. The second aspect of this study documents the rise of interest in the classical guitar across the country during the twentietı century, and shows Canada has become a world claeg centre for the instrument. making significant contributions in the areas of classical guitar performance, education, composition and guitar construction. 


\section{ACKNOWLEDGEWENTS}

It would not have been possible to write this thesis without the assistance of many kind individuals across Canada, especially the guitarists who took the time to respond to my questionnaire and provide essential information for this study. Special thanks go to Stephen Fentok, Ed Honeywell, Eli Kassner, William Laskin, Kolya Panhuysen, Ray Sealey and Caról Van Feggelen for their informative interviews.

Dr. Lucien Poirier of Laval University and Dr. Wesley Berg of the University of Alberta greatly assisted by providing documentation of the history of the guitar in their respective regions. Daniel Levesque translated the correspondence into French, and Kathleen MacSween spent many hours researching old periodicals and newspapers.

I would also like to thank my adviser. Dr. Elaine Keillar. for her criticism and encouragement, and $\mathrm{Dr}$. Jill Vickers for her editorial comments. My special gratitude goes to Bish Sharma for his invaluable insight and comments and his continuous support throughout this study. 
CONTENTS

Title Page

Acceptance Page

Abstract

Acknowl edgements

i i i

Table of Contents

List of Figures and Tables

CHAPTER I : INTRODUCTION

Statement of Problem 1

Hypothesis 4

Review of Literature 6

Methodology 10

Outlines of Chapters 13

CHAPTER II: THE EUROPEAN GUITAR TRADITION

$$
\text { IN CANADA 1630-1850 }
$$

Introduction 15

The Early Guitar 16

The Early 19th Century 29

Conclusion 40

CHAPTER III: THE AMERICAN GUITAR TRADITION

$$
\text { IN CANADA 1850-1920 }
$$

Introduction 45

British Columbia 47

The Prairie Provinces 60

Ontario 64

Quebec 69

The Atlantic Provinces 72

Conclusion 7,;

CHAPTER IV: THE FOIMATIVE YEARS OF THE CLASSICAL GUITAR IN CANADA 1920-1960

Jntroduction 82

The Early Classical Guitar in Canada 84

The Formation of the Toronto Guitar Society 101 Conclusion 108 
CONTENTS

CHAPTER FIVE: THE DECADE OF THE $1960 \mathrm{~S}$

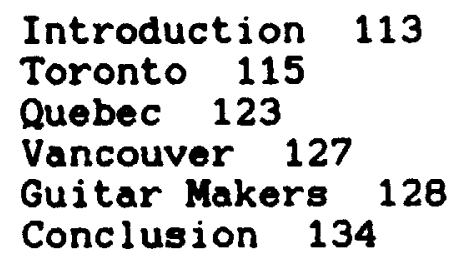

CHAPTER SIX: THE ATTAINMENT OF INTERNATIONAL RECOGNITION 1970-1990

Introduction 136

Performers and Teachers 138

Canadian Compositions for Guitar 149

Canadian Guitar Makers 152

International Guitar Festivals 155

Guitar Competitions 162

Conclusion 164

CHAPTER SEVEN : CONCLUSION

APPENDIX : QUESTIONNAIRES 


\section{LIST OF FIGURES AND TABLES}

Figure II:1 - "Genera! Wolfe Song" 23

Figure II:2 - Mme Bortrand's Portrait 32

Table II:1 - Guitar Music Performed in Canada from 1630-1850

Table II:2 - Guitar Teachers. Performers and Importers in Canada 1630-1859 43

Figure III:1 - Gentlemen Emigrants 58

Figure III:2 - Ukrainian String Orchestras 63

Table III:1 - Guitar Teachers and Performers in
Canada from 1850-1920

Table III:2 - Guitar Music Performed in Canada
$1850-1920$

$\begin{array}{ll}\text { Table IV:1 - } & \text { Classical Guitarists in Canada } \\ 1945-1960 & 109\end{array}$

Table VI:1 - Former Teachers of Canadian Guitarists 142

Table VI:2 - Major Competitions 145

Table VI:3 - Recordings by Canadian Guitarists 148

Table VI:4 - Canadian Made Guitars Owned by Canadian Guitarists

Table VI:5 - Guitar Societies in Canada 167 
CHAPTER ONE

INTRODUCTION

I

STATEMENT OF PROBLEM

The history of the guitar has been one of fluctuation in its popular appeal and use in Western societies. There have been periods of tremendous growth in its repertoire and acceptance, as in Europe during the early nineteenth century and what is being witnessed around the world today. This is contrasted by periods during which the instrument was rarely played except by those associated with the lower class, as in late nineteenth century Euroje. ${ }^{1}$ These trends can also be seen in an examination of the history of the guitar in Canada.

The guitar wasi first brought to Canada during the midseventeenth century by European immigrants. As Canada became more settled. evidence reveals that the guitar began

\footnotetext{
${ }^{1}$ Frederic V. Grunfield. The Art and Times of the Guitar (New York: Collier MacMillan, 1969), p.208.
} 
to be adopted by the middle class during the eighteenth century, becoming especially popular with women. It was not used as a folk instrument until much later, and it did not have the prestige associated with the pianoforte. an instrument of the upper class. The guitar was used with remarkable frequency in early concerts, both as a solo instrument and as a means of accompanying popular European songs.

Before the popularity of the guitar dwindled in the early twentieth century, it acquired a status similar to that of the mandolin and banjo. popular instruments both in the United States and Canada. Stringed groups using combinations of these instruments were common across the country, usually playing the most recent American music.

other styles of guitar playing, such as jazz. folk and blues, were gaining popularity in Canada during the midtwentieth century. The classica! guitar following was small but strong as Andrés Segovia's popularity brought more attention to and acceptance of the instrument. This nucleus was enlarged after the 1950s. As the classical guitar gradually was introduced into concert halls, music faculties and conservatories across Canada, it became a prestigiou. instrument and isolated from the other styles of guitar playing. 
Over the past three decades, Canada has enjoyed numerous achievements in the field of the classical guitar. Canada is home to some of the world's most respected teachers of the instrument, such as Eli Kassner and Caról Van Feggelen. They, in turn, have produced outstanding performers, such as Liona Boyd. billed as one of the top guitarists in the world by Guitar Player Magazine, and Norbert Kraft, winner of the most prestigious international guitar competition. World class guitarists such as Julian Bream and Alice Artz have commented enthusiastically on the talents of Canadian guitar makers. International festivals. the first of their kind in North America, have been established attracting performers and composers from around the world.

Although Canada's guitar history is so rich, there has never been any adequate research done in this area. A few Canadian articles document with little detail classical guitar activity after 1950. and there was no study of the instrument's existence in the country before that time. American and European books written on the history of the guitar make little or no reference to the instrument's existence in Canada. Consequently, readers are left with the assumptions that the guitar was not popular in early Canada, and that Canadians have not made any siçnificant contributions to the guitar world. 
II

HYPOTHESIS

In this thesis. I will demonstrate that the guitar was a very popular instrument in Canada during the eighteenth and nineteenth centuries, taught and sold by some of the country's best known musicians. With the growth of the classical gujtar around the world during the twelliteth century, it is my further assertion that Canada has become one of the leading centres in the world for the classical guitar.

In the first aspect of this study. I will discuss the early guitar in Canada from 1630 to 1920, the period before the various styles of guitar playing, such as classical, jazz, blues, folk and rock, had fully developed. Issues such as the place of the guitar in eighteenth and nineteenth century Canadian society will be explored, as well as early influences on the instrument.

It is my hypothesis that the guitar was largely a woman's instrument during this period of time, although the instrument was usually taught and performed in public by men. I will also attempt to prove that, while from 1630 to 1850, the guitar in Canada was influenced by the European 
guitar, by the late nineteenth century influences were very much American. The evidence I will use will be taken from early concert programmes featuring the guitar. advertisements in newspapers for guitar sales and instruction, and mention of the instrument in ethnic literature.

Because of the development of so many styles of guitar playing in the twentieth century. I will limit discussion in the second part of this study to the classical guitar in Canada. its rise in popularity and early influences. In additior, ? will outline contributions Canada has in turn made to the world of classical guitar, as well as differences between the guitar technique in English and French Canacia. The evidence I will use to support my hypothesis is taken from the study of achievements of individual guitarists and makers across the country compiled through correspondence and personal interviews. Evidence will also be taken from old bulletins of the Guitar Society of Toronto. 


\section{III}

\section{REVIEW OF LITERATUPE}

Books on the history of music in Canada do make occasional mencion of the guitar. Willy Amtmann's book, La Mugique au Québec 1600-1375. for example, includes twelve such references, suggesting that the instrument was especially popular in early Québec. Both Helmut Kallmann's book, A Short History of Music in Canada 1534-1914, and Timothy McGee's book. The Music of Canada, make a few references to the guitar. None of these books, however. addresses specifically the presence of the guitar in Canada or its social status in early settlements.

Numerous books from other countries written about the guitar exist, the majority of which deal with the history of the instrument, its performers and composers, and the evolution of its technique and design. These sources are very valuable in providing a history of guitar activity in Europe during the eighteenth and nineteenth centuries, and in tracing early influences on the guitar in Canada. They make little or no reference, nowever, to the instrument's existence in Canada. This failure to note Canadian achievements leaves the implication that the country has 
made no contributions to the classical guitar world, which, as this study will prove, is an incorrect assumption.

There is surprisingly little written about the history of the classical guitar in the United States, although the country had established a guitar society as early as 1946. Most American books concentrate on the development of other styles of guitar in the country, such as jazz and blues. Peter Danner has written several informative articles on the guitar in the United States during the nineteenth century. These are very useful articles for determining the social history of the guitar in Canada, as the American guitar had a tremendous influence on that in Canada during this same period.

The history of the classical guitar in this country is specifically discussed in three brief papers. In addition. informative articles by Michael Strutt ("Canadian Music for the Guitar"), Davis Joachim ("Guitar Music in Canada"), and Robert Bauer ("Guitar Music in Canada") focus on some of the music written for the instrument by Canadian composers. Other articles in newpapers and periodicals feature specific information about festivals, and biographies of prominent performers, teachers and luthiers across the country. William Laskin's book. The World of Musical Instruments: A Guided Tour, limits his coverage to the guitar makers in Toronto. 
The Encyclopedia of Music in Canada's article on the guitar is the most detailed of the three articles on the history of the instrument in Canada. Well-known performers, teachers and makers are 1isted, and ger.eral information is recorded on the guitar's history in Canada since 1950. Pre-World War II activity however, is limited to one paragraph:

\begin{abstract}
Early references io guitars in Canada are rare.... Guitars were advertised for sale as early as 1752 in Halifax, and gustar strings in 1788 in Montreal. Instruction was of fered in the 19 th century by J.C. Brauneis II of Montreal, and later as part of the curriculum of some ladies' colleg.s and at the [Toronto Conservatory of Musicl. Guitars are seldom mentioned in travellers' accounts from the 19th century. It was not until the twentieth century, and particularly after World War II. that the instrument's popularity in Canada began to grow, and then only in conjunction with a world-wide resurgence of interest.a
\end{abstract}

Canada's contributions to the guitar world are not recognized, and the article does not document how the guitar became accepted in concert halls and music faculties across the country. There are also inaccuracies in the article. such as the statement. "Guitar societies have been established in Edmonton, Ottawa, and Toronto."3 As this study will document, there are, and have been, many other societiez in Canada.

"Helmut Kallmann et al., eds.. "Guitar," Encyclopedia of Music in Canada (Toronto: University of Toronto Press. 1981). p.398.

I Ibid. . p. 399 . 
Part I of Michael Laucke's article, "Growth of the Guitar in Canada." is almost a precise duplication of the above article. The focus in Part II, however, is on some guitar performers, teachers, and composers in Montreal. giving little credibility to the choice of title.

"Short History of Classical Guitar in Canada," by Alan Torok, is centered on the guitar in Toronto. Written to create public awareness of the Toronto Guitar ' 84 festival sponsored by the Guitar Society of Toronto, the article concentrates on the society's history and Canadian composers who received commissions for this festival. Torok writes on the importance of these Toronto festivals:

[Guitar '75] gave the instrument and its practitioners a high profile in Canada and gave notice of the country's increased stature on the international guitar scene. The huge success of Guitar 175 invited a creative and mature approach to what has become a triennial event, the most important of its kind in the world.4

Torok does not mention the guitar's existence in Canada before 1950, but instead focuses on the instrument's rise in popularity since that time. Although he writes on the international impact of Toronto's guitar festivals. Torok

\footnotetext{
"Alan Torok, "A Short History of Classical Guitar" in Canada." Music Scene (May/June 1984), p.25.
} 
does not document other contributions made by Canadians in the guitar world:

The Canadian Encyclopedia's article on the guitar in Canada states, "Although the guitar was brought to Canada as early as the mid-17th century, it had limited use." This statement seems to be the general conclusion in all the articles and books on the history of guitar and music in Canada. There is a false assumption that the guitar was not a popular instrument in Canada during the eighteenth and. nineteenth centuries, and appeared only on rare occasions.

\section{IV}

METHODOLOGY

Since there is so little written on the subject of the guitar in Canada, the majority of information for this study has been acquired through research in archives, and interviews and correspondence with some, f the country's most prominent guitarists and mokers. Early concert programmes, letters, and advertisements found in early

-The Canadian Encyclopedia. 2nd Ed., "Guitar" (Edmonton: Hurtig Publ., 1988), p.945. 
newspapers for guitar instruction and sales provide insight into the areas of Canada in which the guitar was popular before the twentieth century, the sort of music played and by whom.

Research into early guitar activity in Europe and the United States allowed me to determine the influences on the guitar in Canada during a particuiar period of time. It also revealed the popularity of the instrument with specific groups of immigrants to Canada, such as the French and Ukrainians .

Much of the information on the rise in popularity of the classical guitar in Canada after World War II is derived from an oral history. Details on events leading t, the establishment of the classical guitar in educational institutions and concert halls across the country have not been compiled and documented before this time. Many of these facts, therefore, have had to be ohtained through personal interviews with three of the guitarists responsible for the development of the guitar in Canada: Eli Kassner of Toronto, Stephen Fentok of Montreal, and Caról Van Feggelen of Halifax.

Other prominent guitarists such as Ray Sealey and Ed Honeywell of Ottawa were also kind enough to agree to interviews, as did guitar makers William Laskin and Kolya 
Panhuysen of Toronto. Unfortunately, financial and time limitations made it impossible to meet personally with other guitarists, makers and composers across the country.

A questionnaire was sent by me to each department of music and major conservatory in Canada in which guitar instruction is offered. I compiled the list of institutions and names of guitar instructors from university and college calendars and telephone calls to conservatories, resulting in a total of fifty questionnaires being sent across the country. In order to ensure maximum response, the number of questions was kept to a minimum, and a French questionnaire. translated by Daniel Levesque of Ottawa. was sent to Frenchspeaking guitarists. Copies of these questionnaires are included in the appendix of this study.

Twenty-six guitarists of a potential fifty replied to the questionnaire, and the majority enclosed additional information on their contributions to the guitar in Canada and the status of the instrument in their region of the country. Information on some of the guitarists who did not reply was compiled from biographical notes in the Encyclopedia of Music in Canada and various newspaper and magazine articles. 
V

OUTLINES OF CHAPTERS

The first area of study in this thesis, the guitar in Canada from the seventeenth century to the early twentieth century, can be divided into two periods, according to the major influences on the guitar during that time. The first of these, European influences on the guitar in Canada, is found in chapter two. The presence of the guitar and its social status in early pioneer settlements from 1630 to 1850 are explored in an effort to demonstrate that the use of the guitar in Canada was greatly influenced by the guitar in Europe during the same time period.

The American influence on the guitar in Canada is outlined in chapter three. This covers the period from approximately 1850 to 1920 . In this chapter, it is argued that most of the music and guitars were imported from the United States into Canada during this period of time, resulting in the transplantation of an American musical cul ture.

Chapter four explores the resurgence of the classical guitar around the world in the twentieth century, and the resulting developments in Canada. The chapter documents the 
first classical guitarists in Canada and their offorts to raise the standard of playing and the prestige of the instrument in various regions of the country. The continuation of this growth of the guitar across the country during the 19608 is discussed in chapter five. The development of a thriving guitar making industry in Canada and the role of the Guitar Society of Toronto in North America are also explored.

The attainment of international recognition for the achievements of Canadian classical guitarists is the subject of chapter six. The contributions of individual guitarists as well as international and provincial festivals and competitions are also documented. This chapter will demonstrate that Canada is now in a position to influence other countries in the field of the classical guitar, having achieved world class standards in guitar performance, education, composition and guitar making.

Chapter seven concludes this study and attempts to provide an overview of the history of the guitar in Canada. The various phases it has undergone during the course of its history in this country are analysed, as are the reasons for its long history of popularity in Canada. Limitations of this thesis and suggested areas for further research in this field are also put forth. 
CHAPTER TWO

THE EUROPEAN GUITAR TRADITION IN CANADA:

$1630-1850$

I

INTRODUCTION

This chapter will explore the existence of the guitar in Canada from 1630 to 1850. It will attempt to prove that the instrument was widely used in Canada by immigrants during this period, and was taught, sold and performed by many of the country's early musicians.

The European influences during this time on the guitar in Canada will also be explored. This chapter will attempt to establish that the Canadian guitar culture was very much influenced by the European guitar tradition. It will show that the music performed during Canadian concerts was European, instruments and strings were imported or brought over from Europe, and guitar teachers in Canada were European trained. 
As will be demonstrated, there was ar. attempt to duplicate in Canada the guitar's European social status. The guitar in Canada became an instrument of the middleclass, largely taught to and played by women, although rarely in public. It was not used as a folk instrument, but as a form of accompaniment to the voice or for playing solo pieces. Any changes in the guitar's status in European countries were reflected in the guitar's status in Canada.

II

THE EARLY GUITAR

As early as the 1630s. French and Indian children at Québec City were taught to sing and play European instruments. Viols, violins, guitar, transverse flutes, drums, fifes and trumpets are among the instruments named in early accounts, but it would be wrong to conclude that all were cultivated continuously in New France. 1

From this first known reference to the guitar in Canada, the instrument's existence is fairly continously noted. Undoubterly, early settlers in the country would have been glad to have had a musician among them, regaldless

${ }^{2}$ Helmut Kallmann. "Music History." Encyclopedia of Canada. 2nd Ed. (Edmonton: Hurtig Press, 1988), p.1416. 
of the instrument played. The instruments and music brought over to Canada, however. would have reflected the musical taste of the time in their country of origin. The guitar. being a portable instrument. versatile, suitable as an accompaniment to the voice, fairly easy to learn the basic techniques, and with fewer tuning prob!ems than the lute, was a suitable instrument for early pioneer life.

In the early seventeenth century. tive-course guitars were played in both France and Italy.2 It is impossible to know what sort of guitar music was taught to the children in Québec City during this period, but it is quite probable dance music was introduced. The instrument was extremely popular as an accompaniment to dances in both France and Italy in the early seventeenth century. ${ }^{3}$ Italy alone produced over fifty books of popular dance pieces for the guitar between 1606 and 1629. There are increasing references in the seventeenth century to the love of dancing by settlers in New France and perhaps some of the music for the dances was provided by guitarists who knew this music.

During this same period, the guitar's prestige and technical demands made upon its players decreased.

${ }^{2}$ A five-course guitar had a combination of single and pairs of strings tuned in unison or at the octave.

3Frederick V. Grunfield, The Art and Times of the Guitar (Toronto: Collier-MacMillan Canada, 1969), p.106. 
In the 16th century, the guitar had made itself respectable and became incorporated into upper-class life, but now [early 17 th century] it harked back to its humbls origins as a simple strumming instrument used only for accompaniment. Concentration on basic chordal texture and basic rhythm replaced the contrapuntal style of the older vihuela and four-course guitar.a

These changes in the guitar's technique would have made the instrument more popular with the early settlers in Canada.

Dance tunes used a basic strumming pattern notated on tablature, siriliar to today's chord charts, making the instrument easior to learn.

A specific reference to the guitar in Canada is found in a letter written on October 4,1658 by Mother Marie de l'Incarnation, also from New France.

The French at Onondaga had discovered that the Iroquois were plotting to kill them. There was nothing the French could do but escape. They conceived a counterplan according to which they let the Indians enjoy a noisy festivity. so noisy indeed that the French could secretly prepare their departure. After the Indians had feasted. danced and shouted to the sounds of flutes, trumpets and drums, a French boy who had been adopted by an Iroquois lulled the tired men to sound sleep with his guitar playing. At this point the French made a safe escape.

Tom and Mary Anne Evans. Guitars: From the Renaissance to Rock (New York: Paddington Press, 1977), p.110.

SHelmut Kallmann. A Short History of Music in Canada 1534191.1 (Toronto: University of Toronto Press, 1960), p.19. 
From the year, and the nationality of the boy, one can assume that the guitar would have probably been a fivecourse instrument. Its popularity had surpassed that of the traditional lute in France by this time, even played by the King himself.

In a method book published in 1626. Luis de Briceno accounted for the growing popularity of the guitar. especially with the ladies of France.

But the guitar, my lady, whether well played or badly played. well strung or badly strung, is pleasant to hear and to listen to; being so easy to learn, it attracts the busiest of talented people and makes them put aside loftier occupations so that they may hold a guitar in their hands. They desert the lute, theorbo. cittern, and clarichord, all for the guitar. Many things could be said in faror of these instruments, but here one consideration is paramount: two thousand people now entertain themselves and express their thoughts and troubles through the guitar. And as further proof of the value of my guitar ask yourselves whether kings, princes and gentlemen lay aside the guitar for the lute as they now leave the lute for the guitar?6

Higher class Europeans who settled in Canada tried as much as possible to duplicate in the new country their elite society. It seems likely, therefore, that many of the more wealthy women in Canada during this time played the guitar. maintaining this tradition of their homeland.

Grunfield. Tre Art and Times of the Guitar. p.109. 
It is not until the mid-eighteenth century that the guitar is again mentioned in early Canadian documents. Tnis is not surprising as Helmut Kallmann notes that little is documented on music of any sort being played in Canada during most of the eighteenth century.

The eighteenth century. except for its final decades, is a rather dark age in the recorded music of Canada. ....it may be assumed that during the first sixty or seventy years of the eighteenth century music continued much along the lines established in the seventeenth century: as faithful companion of religion, work, travel and leisure hours.?

In 1752. Mr. John Smith of Halifax advertised the sale of guitars and violins. This is the first reference to the use of the guitar by English settlers. Advertisements of this nacure can be found in Halifax papers until the end of the century.

Advertisements placed by three dealers in stiff competition with one another and with two auctioneers reveal that in the 1770 s and early 1780 s the following items were sold: a chamber organ, several pianofortes, violins, guitars, spinet strings, etc. ${ }^{\circ}$

In 1791, music instruction books, guitar strings and frets were advertised by Charles Geddes, and in 1793, "Two handsome guitars, tortoiseshell, fingerboards and spare

\footnotetext{
TKallmann, Music in Canada. p.27.

-Frederick A. Hall, "Musical Life in 16th Century Halifax." Canadian University Music Review 4 (1983), p.283.
}

Ibjd. p. 283. 
stringe with Smith's patent machine"10 were being sold by Hall, Bremner and Bottomley of Halifax.

Without knowing more details, it is difficult to determine what sort of guitars were being sold in Halifax and where they were made, although the use of tortoiseshell suggests that these particular guitars were likely made in France.

A notable feature of the most lavish of the Parisian school is the use of tortoiseshell as a veneer to the sides, back and neck.11

The guitar in Europe was going through an enormous period of transition during this period. Tied gut frets such as those advertised by Geddes were replaced with fixed brass frets, although there was no established number of frets.12 Tuning heads such as those manufactured by Smith were replacing wooden pegs. By the late eighteenth century, six-string guitars were becoming more popular than those with five and six courses. Until the end of the century, however, guitars were generally inferior as musical instruments.

20Hal1. "Musical Life in 18th Century Halifax," p.284.

${ }^{11}$ Evaris and Evans, Guitars, p.25.

${ }^{22}$ Grunfield. The Art and Times of the Gujtar. p.144. 
Guitar makers produced highly ornamented works of craftsmanship, and their instruments were greatly valued as "objets d'art." However, their love of ornate filigree made these instruments more like decorated cabinets than true musical instruments and they were $f$ it for little more than accompanimencs to the voice or elementary solo music.13

Little is documented on the type of music actually played in Halifax during this period. "General Wolfe. A Much Admir'd Old Song" (given in Figure II:1), by Thomas Smart, 14 is an example of a song on a Canadian topic from the end of the eighteenth century, the precise date being unknown. There is a part written out for the German flute or guitar, almost duplicating the piano and vocal parts. Instead of chording, as one might expect, the guitarist must play quite a demanding part, reaching up to high $E$ with numerous trills and grace notes, using a fairly complex rhythm. It is not known if this was ever performed on the guitar, but Smart may have had a guitarist in mind when scoring for the instrument. In any event, this song with its recent historical theme was popular among Canadian settlers of British origin.

There was also much guitar activity in French Canada during the latter part of the eighteenth century. Two men

23raham Wade. Traditions of the Classical Guitar (London: John Calder, 1980), p.6.

14In his research. F. Hall was unable to uncover any further information on Thomas Smart. 
FIGURE II:1 15

\section{GENERAL WOLFE}

A much adosid OLD, Soss

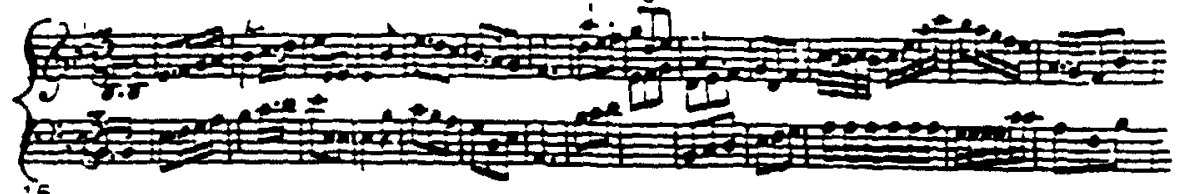

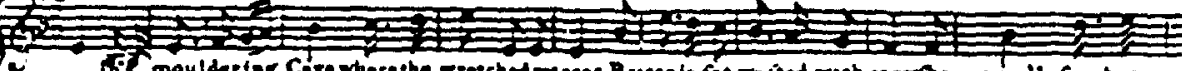

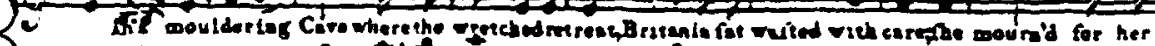

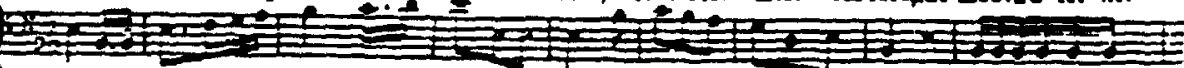

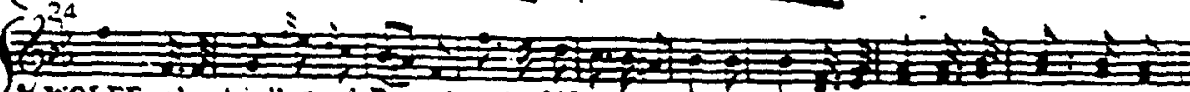

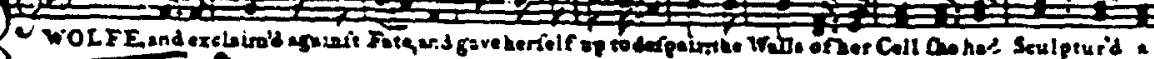

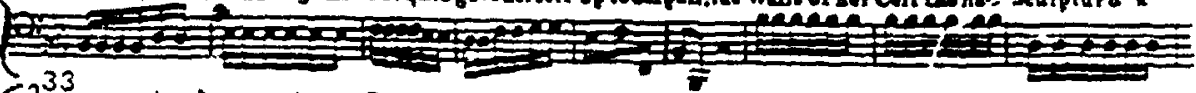

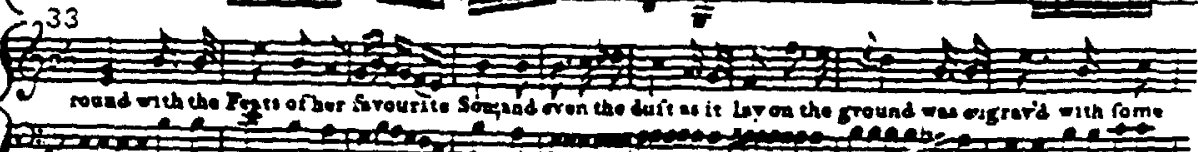

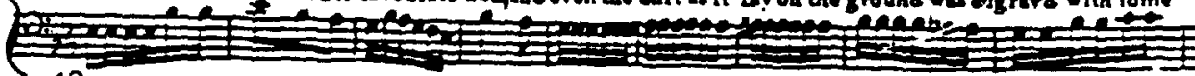

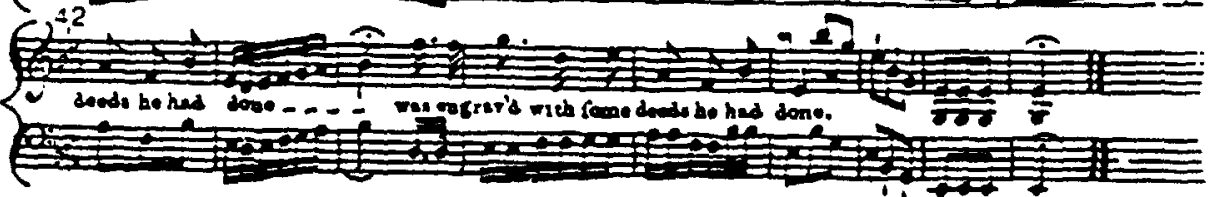

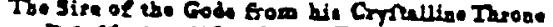
The difeogrolete Damt

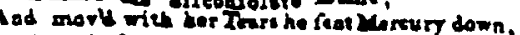
And thefe wart the Tidings the come:

BRITASILA, forber, dot a sigh or E Twor For thy WOLFE fo defervally lord;

Your Tret: Reil be chang'd lato irie maphs wi Joy, For th WOLFE is aot daed bet semord.
The swo or che kaft, the proed Giente of 0 !d Have cropt from their datik forn. aboder: And this to the Nerro $w$ in Hewra it wor told, They wore Marching to Wh meh the Godi:

A Cordecil wa beld is the Chumbers of JOVE, And thi. wee theif flowl dectes.

That WOIFE Bauld be collat to the Arroy sbove, thd the Caste wee utrufted $10 \mathrm{me}$

To the Platas of Quebeck, with the Ordars $1 \mathrm{~nm}$ E. bectd for a momeurs deley:

Le cry'd, Ob forben, let me Victory heer, And ines by Comound, l'u obey:

With oderkiome thet Film I mcomparr'd his Eyos, Ald bore bem smay in in $\mathrm{Crm}$

Left the fondnofi he bore to bis ow Xietive skore,

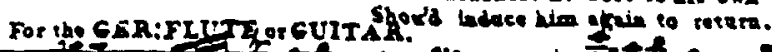

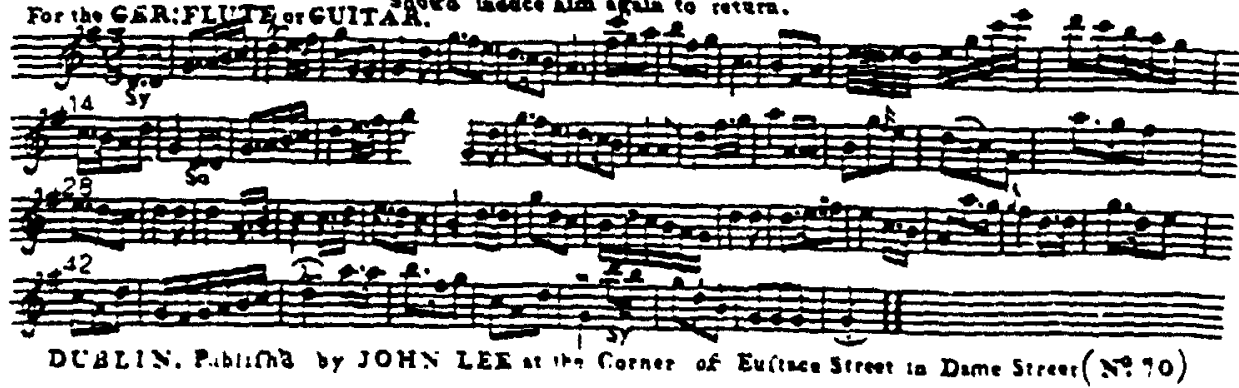

${ }^{15}$ Frederick A. Hall, The Canadian Musical Heritage: Songs I (Ottawa. 1985), p.3. 
were largely responsible for this interest - Monsieur Jouve and Frederic-Henri Glackemeyer.

Glackemeyer (1751-1836) was born in Germany, where he received his musical training on the violin. As a teenager re moved to Quebec City. where he remained as an influential musician until his death.16 In addition to importing. tuning, and repairing instruments, Glackemeyer started subscription concerts in which he also performed. Several advertisements for the sale of guitars and strings appeared in the Gazette de Québec during the 1780s, all the effort of Glackemeyer. In 1788, he announcer, "Guitars tuned and neatly repaired."17 The following announcement appeared in the Québec Herald in 1790:

Frederick Glackemeyer has for sale, up stairs, at No. 25 Mountain Street, next door to the Herald Printingoffice, the following articles,

Guittar [sic] strings...

A choice collection of songs in sheets, quite new. for the harpsichord, guittar, and German flute...

Harpsichords, piano fortes, guittars, and all sorts of musical instruments, repaired and tuned on the shortest of notice and the most reasonable terms. Music copied in the neatest style.10

There seems to have been an interest in the instrument in the city, as tuition on the guitar was even a part of the

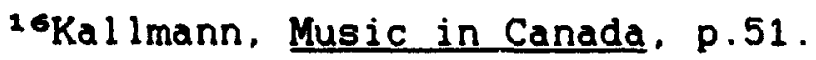

17Willy Amtmann. Music in Canada 1600-1800 (Québec: Habitex Books, 1975), p.277.

10 Québec Herald, 20 May 1790, p. 201. 
Young Ladies' Academy Prospectus at the Irsuline Convent in Québec during the $1790 \mathrm{~s} .20$ The instrument was largely taught to women, as music lessons for men were generally frowned upon.

There was a strong prejudice against teaching music to men, so strong indeed that Glackemeyer, who made accomplished musicians out of his daughters, refused to teach music to his sons.20

As will be seen, this attitude toward women and music lessons continued for many years in Canada.

The other important figure in guitar history in FrenchCanada during this period. Monsieur Jouve, was a teacher and performer of the instrument, both in Montreal and Québec City. He arrived in Québec from England in 1791 with His Royal Highness, the Duke of Kent22, and "immediately set about selling music, promoting concerts, and offering lessons in voice, harp, cello, and French guitar."za Jouve offered lessons on "le guitare française, instrument trés facile et trés agréable, avec lequel on s'accompagne en peu de temps en chantant."23

\footnotetext{
1.Amtmann, Music in Canada. p.305.

aoKallmann, Music in Canada, p.54.

21Amtmann, Music in Canada. p.223.

aaWilly Amtmann, La Musique au Québec 1600-1875 (Montreal: Les Editions de l'Homme, 1976), p.304.
}

23Ibid.. p.301. 
Jouve also performed concerts with "la guitare française." On February 21, 1792, he advertised his upcoming concert at "La Nouvelle Salle des Spectacles" in Québec City as "un concert vocal et instrumental à son bénéfice, dans lequel il fera entendre le dit instrument et la guitare française." 24 During this concert. Jouve performed "Ariettes Boufonnes d'Opéras Comique" accompanied by the French guitar. This was the last that was heard of Jouve, and it is presumed that he returned to England in 1792.28

The instruction offered by Jouve on "la guitare française" consisted mainly of basic strumming techniques and chords, making the instrument accessible even to the least talented students. Less expensive than a piano-forte and easier to transport to the new country, the guitar would have provided an alternative accompaniment to the voice in early Québec homes.

Jouve and Glackemeyer were not the only people selling guitars in Québec during this period. An advertisement by Jacques Sinclair appeared in the paper in 1782, two years before that of Glackemeyer. Both guitars and strings were

\footnotetext{
24Amtmann, La Musique au Québec. p.303.

25Amtmann. Music in Canada. p.223.
} 
being sold.20 A musician by the name of Francis Vogeler (1788-1820) was also teaching and selling guitars, and in 1789 placed the following advertisement in the Québec Herald:

For sale by Francis Vogeler Guitars

Instruction given on the piano forte, violin, guitar. German flute and other wind instruments. ${ }^{27}$

Unfortunately, more information is not known about these two men.

The guitar did not appear to be a popular instrument for playing dance music during the eightenth century, but instead was used mainly as an accompaniment to the voice or as a solo instrument. The fiddle was a more popular instrument for accompanying dances.

Dancing was the ruling passion of the Canadians. according to a letter written in the $1790 \mathrm{~s}$ by an Englishman. The dance tunes were played by the village fiddler or piper, and when no instrumental performer could be found, clapping, whistling, or singing would mark the rhythm. In French Canada the "giumbarde" (Jew's-harp) was a popular instrument. and during the niseteenth century the clarinet and guitar became popular. 20

${ }^{26}$ Amtmann, Music in Canada, p. 282.

27Québec Herald. 15 June 1789, p.267.

20Kalimann. Music in Canada. p.37. 
Certainly the small sound of the guitars constructed during the eighteenth century would have been a factor in the instrument's lack of popularity as an acccmpaniment for dances. The following anecdote, which appeared in La Gazette de xontréal in 1786, however, suggests that the guitar was used occasionally to provide dance music:

\begin{abstract}
Anecdote
Few days ago one zealous overmuch, reprobated his neighbour for being at a dance assembly. The neighbour plead the example of King David in excuse: But, replied the other, David only danced a minuet, to a divine tune, played on the harp: whereas, ye now dance jiggs, reels, hornpipes, and country-dances, to profane tunes, played on guitares, violins, flutes, hautboys, and fiddles: nay ye even dance pantomines, to the tune 0 'pheus played for the devil, when he charmed back his wife. 20
\end{abstract}

During the eighteenth century in New France, the use of guitars to provide dance music seems to have been the exception rather than the customary practise. The instrument wos primarily adopted by the middle class in Quebéc, those able to afford the luxury of musical instruments and instruction, yet not able to afford a pianoforte.

29. Gazette de Montréal. 23 February 1786, p.3. 
I I I

THE EARLY NINETEENTH CENTURY

Montreal dominated the first half of the nineteenth century of known history in Canada. References to performances, teaching and instrument sales document the presence of the instrument in French society of the day.

J.J. Bigsby, a traveller to Canada, made mention of the guitar in his accounts of Montreal in 1820.

After coffee madame called upon her daughter for a romance to the guitar, which she gave at once, very unaffectedly and well.30

In his study of music in Canada during this period, Barclay McMillan noted the preemirience of women as instrumental performers and the use of piano and guitars for accompaniment. 32

This phenomenon was also explored by Cheryl Gillard in her thesis, "Women in Music in Canada: An Introduction." She stated that during the eighteenth and nineteenth

${ }^{\circ}$ Barclay McMillan. "Music in Can-da 1791-1867: A Travellers' Ferspective" (Unpublished MA Thesis, Institute of Canadian Studies, Carleton University, 1983), p.52.

31 Ibid. , p.54. 
centuries, "the piano, the harp and the guitar were deemed as the most acceptable feminine instruments." 32 Helmut Kallmann also noted that although women were taught to play these instruments, they were not encouraged to perform in public.

Playing an instrument was admitted as a pleasant pastime and a definite asset for mariageable daughters - on the same plane as baking or embroidery. A musical career was generally discouraged or frowned upon. 33

This attitude toward women and the guitar originated in Europe. The popularity of the guitar with the ladies in eighteenth century Europe continued well into the nineteenth century. In 1804, Werden wrote of this social custom in his publication. Taschenbüch für Freunde der Musik:

Isn't it true that it can be found in the home of every even only moderately modern, attractive. affectionate. flirtatious, playful, pretty, exhuberant, mischievous or even innocent, demure, respectable woman? And that every day new songs, choruses, romances, duets, trios. solos, sonatas, potpourris, chansons, contredanses. anglaises, waltzes, minuets, allemandes, and rondos. yes even concertos, are created, written, composed, produced, and arranged for the guitar?34

32Cheryl A. Gillard. "Women in Music in Canada: An Introduction" (Unpublished MA Thesis. Institute of Canadian Studies, Carleton University, 1987), p.15.

$33 \mathrm{Kallmann}$, Music in Canada, p.112.

${ }^{34}$ Grunfield. The Art and Times of the Guitar, p.169. 
A painting of Mme C. Bertrand of Outremont done in 1824 (see figure II:2), possibly by William von Moll Berczy, 30 further supports the theory of the guitar being especially popular with the women in Canada, as in Europe. The painting depicts Mme Bertrand piaying a French guitar with eighteen fixed frets and what appear to be six single strings. This would be the type of guitar very fashionable in Paris during this same period. although it lacks the newest style of fingerboard.

Although fingerboards extending to the soundhole appear from the 1820s, many continued to be built

(particularly in Mirecourt) with the old style of flush fingerboards.... Paris guitars were similar in many respects to their Italian counterparts, but more plainly decorated and with a different soundboard bracing. 36

English women were also playing the guitar, and those who emigrated to Canada brought their instruments with them. John Langton, an English emigrant, settled at Sturgeon Lake. Upper Canada, in 1833.

In April of that year. Langton wrote to his father that while the population of the lake was only six. four of the settlers were Oxbridge men, and one was a graduate of the Royal Military Academy at Woolwich. "The sixth." Langton wrote drolly, "though boasting no such

38J. Rust Harper, Painting in Canada: A History (Toronto: University of Toronto Press, 1966), p.71.

36Michel Foussard, ed. Guitares (Paris: La Flûte de Pan, 1980), p.133. 
FIGURE II: 2 37

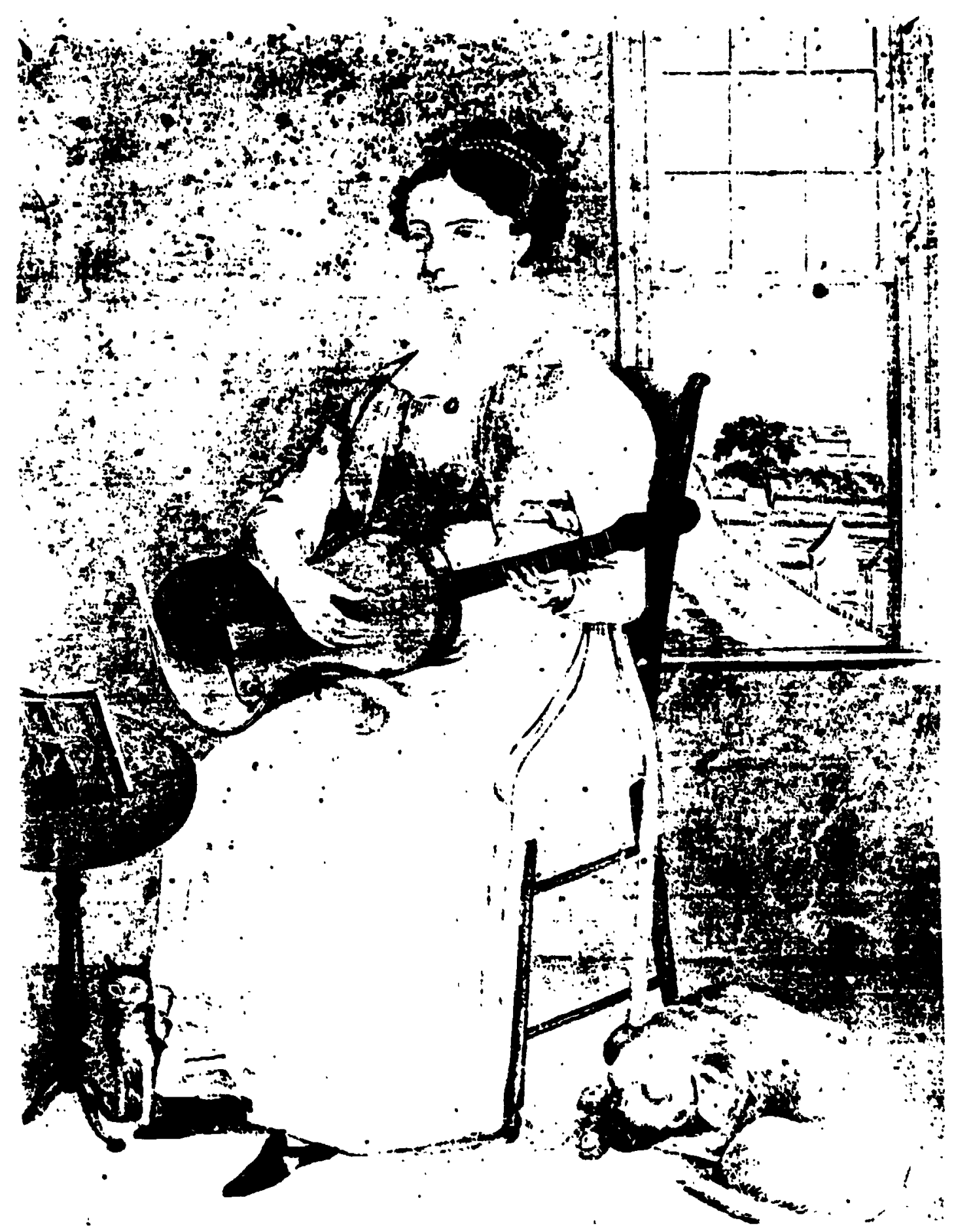

37J. Russell Harper, Painting in Canada: A History (Toronto: University of Toronto Press, 1966), p.71. 
honours, has half dozen silver spoons and a wife who plays the guitar." 30

By the 1840 s, guitar instruction for middle-class women became an established part of the curriculum at many educational institutions in Canada.

Music began to assume a regular place in the education of the middle classes, and music teachers were engaged by many of the "higher ladies' academies." The Adelaide Ladies' Academy in Toronto, Misses Dunn's School for Ladies in Cobourg, and the Burlington Academy in Hamilton of fered instruction in piano, harp. guitar, and vocal music.... In Sackville. New Brunswick, music was taught from 1854, when a ladies' college was established at Mount Allison. 39

There was an attempt by many immigrants to Canada to transplant the culture from their homeland to the new country. Just as it was a status symbol in Europe for a woman to be able to play the guitar, it maintained the same meaning in many parts of Canada. The majority of guitar teachers and public performers in the country, however, were men.

One of these teachers was Jean-Chrysotome Brauneis II (1814-1871). Although there is little information about his guitar activity, he was reported to have taught the instrument in Québec. From 1830-1833. Brauneis studied

sepatrick A. Dunae, Gentlemen Emigrants (Vancouver: Douglas \& McIntyre, 1981), p.22.

${ }^{30} \mathrm{Kallmann}$, Music in Canada, p.113. 
music in Europe, one of the first Canadians to have done so, then taught for many years at the "Institut de la Congrégation Notre Lame" and in other educational institutions.40 Brauneis would certainly have heard the guitar played in Europe during his period of study. but unfortunately more information must be uncovered to know what repertoire he taught and what successes with the instrument he enjoyed, if any.

A guitarist by the name of Signor Jean Muscarelli performed guitar pieces during concerts in Montreal in 1830 and 1831. Little is known of his background except that he was from Italy and was a member of the "Milan Opera."41 His country of origin was reflected in his repertoire.

Following are the guitar selections from these concerts:

May $20, \quad 1830$

1. Variations sur la guitare - "Della opera de Eliza E. Claudio." par Mercadante

2. Waltz avec variations sur la guitare - Carulli

3. Chanson - "Di Tanti Palpiti." accompaniment sur la guitaresz

$\underline{1831}$

1. "O Dolce Concerto," avec variations à la guitare

2. Valse, avec variations à la guitare

3. Theme, avec variations à la cuitare

4. Chant Italien "L'Amore" - guitare

${ }^{40} \mathrm{Kallmann}$ et al. Encyclopedia of Music. p.112.

${ }^{4} \mathrm{Kallmann}$. Music in Canada, p.84.

${ }^{40}$ Amtmann, La Musique au Québec, p. 337. 
accompaniment 43

Ferdinando Carulli (1770-1841), an Italian guitarist and composer who spent most of his life in France, wrote a Méihode Complète pour la Guitare, published in Paris in 1810. Selections, such as the "Waltz and Variations" Muscarelli performed in Montreal, were included in Carulli's manual.

A concert announcement in November of 1842 brought news of a roman performing publicly on the guitar, the first Canadian woman known to do so.

Mme de Goni et Mons. Knoop donnent ce soir. à l'hôtel de l'arcade, une seconde soirée de musique instrumentale. L'exécution de Mme Goni. sur la guitare, est vrainient étonnante.44

Later in that decade, another woman guitarist by the name of Mrs. Stennett advertised music lessons in Montreal.

Professor and teacher of music including the pianoforte, guitar, singing, etc.

No. 45 Bleury street

Gives lessons either at her own residence. or at those of her pupils. 45

\footnotetext{
4amtmann, La Musique au Québec. p.338.

44 Amtmann, La Musique au Québec, p.367.

45Montreal City Directory, 1847, p.58.
} 
Unfortunately, additional nformation on the lives of these women or their musical background is not known. What is evident, however, is that it was very unusual for a woman in Canada to teach or play the guitar in public during this period. Me de Goni and Mrs. Stennett were definitely going against the norm of their time.

An advertisement placed in La Minerve by Messrs. Mead, Frères \& Ce. in 1844 detailed the wide selection of guitars available to residents of Montreal at that time:

Instruments de musique, venant de Paris, comprenent un assortiment de guitares d'Espagne, d'Italie et de Paris, de toute description. 46

Spanish guitarist Fernando Sor (1778-1839) commented in The Giulianiad on the quality and amount of guitar construction in Europe during the first half of the nineteenth century.

The manner of constructing the body of the instrument is almost everywhere understood extremely well, and most Neapolitan. German and French guitars leave, in this respect, very little superiority to the Spanish. ${ }^{47}$

46Amtmann, La Musique au Québec, p.281.

47The Giulianiad, p.56, as quoted in Harvey Turnbull, The Guitar: From the Renaissance to the Present Day London: Batsford, 1974), p.68. 
Guitars from each country, however, retained distinct characteristics.

In the other countries of Europe, makers continued to work along more or less independent lines, and national characteristics can be distinguished. The most noticeable feature of northern guitars is that the waisting is sharper; the upper and lower bouts were widened to produce a "double circle" body shape while in the South the shape of "two joined ovals" was preferred.40

There is no documented evidence of guitars being built in Canada before the wal-nineteenth century, but $\mathrm{Cl}$ ifford Ford suggests that some instruments were in fact constructed by early European settlers.

Although the viol in had been indispensable as the folk instrument of Canada's early settlers, the emergence of the piano as the favourite instrument of genteel society precluded any large-scale development of a violin-making industry here. However, quite often these small instruments - violins, guitars, etc. - were made or repaired by individuals as a part -time or retirement activity and, therefore, were probably much more widespread than our documented evidence would lead us to believe. 40

Even without Canadian-made guitars, there seems to have been a surprising variety and quantity of guitars available in early Montreal, however, all of the latest European design.

\footnotetext{
48 Terrence Usher. "The Spanish Guitar in the 19th and 20th Centuries," Galpin Society Journal 10 (1956), as quoted in Turnbul1, Guitars, p.69.
}

${ }^{4} \mathrm{Cl}$ ifford Ford, Canada's Music: An Historical Survey

(Agincourt: GLC Publ., 1982), p.60. 
In addition to guitars being imported from Europe, the most up-to-date music and method books were also brought over. By the mid-1800s, instrumental music was starting to appear in literary journals in Quebec. Le Ménestrel was one such publication, although it only lasted from June 1844 to January 1845. One edition made mention of piecss published for the guitar such as, "Une Romance pour guitare intitulée - Le Lac des Fées."so In 1850, an article appeared in La Canadien criticjsing the lack of music for the guitar in this particular journal:

Since we are to express our opinion on the music in the album, we are taking the liberty of making some remarks that many of our subscribers have made to us. The publisher should vary the selection of musical comp.isitions and alternately present pieces for piano. harp, guitar, flute and violin.81

Although there was an obvious interest in new music for the guitar, this suggestion did not seem to have made an impact on the publisher as there is no reccrd of any music for the guitar being published in that particular journal. There are also no references to any guitar solos or method books being published in Canada during this time.

\footnotetext{
80Maria Calderisi. Music Publishing in the Canadas 1800-1867 (Ottawa: National Library of Canada, 1981), p.24.

${ }^{81}$ Ibid. . p. 263.
} 
In Europe, the guitar was seeing the last of the immense popularity it enjoyed during the first half of the nineteenth century before a period of dormancy lasting until its revival almost one hundred years later. Henri Blanchard wrote an article to this effect in the 1842 edition of the Gazette Musicale:

The race of Patagonians, of which some gigantic remains are still sometimes found in Tierra del Fuego, have disappeared from the surface of the earth. The same is true of guitar players. What is a guitar player among the incessantly growing population of instrumentalists? An atom, a nonentity ... a fifth wheel on the wagon.sz

The guitar continued to be a popular instrument with the upper class women in England until the late nineteenth century, but Spain remained the only European country where the guitar. its national instrument, stayed at the forefront of musical activity.

The loss of the guitar's prominence in many of the European countries had an impact in Canada during the second half of the nineteenth century. An article written in 1875 for Le Canada Musical, entitled "La Musique," stated:

Et la guitare, la mandoline, instrument favoris des serenades espagnoles. Elles brillerent à la cour de

"3enri Blanchard, "Les Guitaristes," Gazette Musicale (1842). as quoted in Grunfield. The Art and Times of the Guitar. p.208. 
Louis XIV; aujourd'hui on ne les entend plus.ss

The guitar did not disappear from Canada, as suggested by the author of "La Misique," but merel: underwent a transition. The European tradition of the guitar in Canada. however, had come to an end.

IV

CONCLUSION

Evidence clearly indicates that the guitar has been in existence in Canada since the seventeenth century. Since guitar music. instruments and strings were not produced in Canada during the period discussed in this chapter. they had to be brought over by settlers or imported from Europe. This resulted in the guitar in Canada being directly influenced by changes in European guitar design, techniques and repertoire.

A list of all the known titles of guitar pieces performed or made mention of in Canada from the seventeenth

- Ie Canada Musical. "La Musique.". 2, No.8 (1 December $1875), 118$. 
TABLE II : 1

GUITAR MUSIC PERFORMED IN CANADA FROM 1630 TO 1850

\begin{tabular}{|c|c|c|c|}
\hline TITLE OF PIECE & DATE & NATIONALITY & INSTRUMENTS \\
\hline "General Wolfe" & 1790 & Canada (?) & $\begin{array}{l}\text { Guitar, Voice } \\
\text { Piano,Flute }\end{array}$ \\
\hline $\begin{array}{l}\text { "Ariettes Boufonnes } \\
\text { d'Opéras Comique" }\end{array}$ & 1792 & France & Guitar, Voice \\
\hline "Romance" & 1820 & France & Guitar \\
\hline $\begin{array}{l}\text { "Della opera de Eliza } \\
\text { E. Claudio" }\end{array}$ & 1830 & Italy & Guitar \\
\hline $\begin{array}{l}\text { Carulli "Waltz and } \\
\text { Variations" }\end{array}$ & 1830 & Italy & Guitar \\
\hline "Di Tanti Palpiti" & 1830 & Italy & Guitar, Voice \\
\hline $\begin{array}{l}\text { "O Dolce Concerto" } \\
\text { Variations }\end{array}$ & 1831 & $\begin{array}{l}\text { Italy } \\
\text { (Mozart Theme) }\end{array}$ & Guitar \\
\hline $\begin{array}{l}\text { Chant Italien } \\
\text { "L'Amore" }\end{array}$ & 1831 & Italy & Guitar \\
\hline
\end{tabular}


century to the mid-nineteenth century (given in Table II:1) reflects the European influences in Canada during that period. There are no American pieces named, and only one possible Canadian work included a guitar part of any kind ("General Wolfe"). The remainder of the pieces are from Italy or France and can be divided into two categories guitar solos and arias from operas or popular songs with guitar accompaniment.

The guitar music being taught and performed in Canada was obviously influenced by those doing the teaching and performing. A survey of the known backgrounds of all musicians in Canada teaching or performing on the guitar during this period (given in Table II:2) indicates that all were born and received their musical training in Europe with the exception of J.C. Brauneis II, who was born in Canada but studied music in Europe. These musicians would likely have taught guitar to Canadians using some of the numerous European guitar method books available during the eighteenth and nineteenth centuries. Similarly, they would have performed selections from their guitar repertoire obtained in Europe.

With the exception of two women, all known guitar teachers and performers in early Canad: were men. Instruction on the instrument, however, seemed to be largely offered to middle-class women. The pianoforte was the elite 
TABLE II : 2

GUITAR TEACHERS, PERFORMERS AND IMPORTERS IN CANADA FROM 1630 TO 1850

NAME

John Smith

Monsieur Jouve

Slackmeyer

J.C. Brauneis II

Mme Goni

Eng land

Germany

European

Training

\section{Italy}

COUNTRY OF BIRTH AND MUSICAL EDUCATION

EUROPE

CANADA

USA

UNKNOWN

Québec

Mrs. Stennett

Charles Geddes

Francis Vogeler

Germany

$\star$

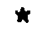

*

Jacques Sinclair 
instrument of the time, with the guitar being an alternative for those who could not afford the pianoforte. Both instruments enabled a woman to provide an accompaniment for the voice or entertain in the home with short solo pieces. The luxury of musical instruction could only be afiorded by women of the middle or upper class.

The guitar in Canada during this period was in effect the European guitar tradition duplicated in the new country. With the disappearance of that tradition in Europe in the mid-nineteenth century, the guitar in Canada did not follow but became more influenced by American developments. This transition will be further explored in chapter three. 
CHAPTER THREE

THE AMERICAN GUITAR TRADITION IN CANADA:

$1850-1920$

I

INTRODUCTION

This chapter will attempt to prove that the guitar in Canada during the second half of the nineteenth century and the first two decades of the twentieth century was influenced by musical trends in the United States. Evidence to support this argument will be taken from references detajling the selection of instruments available in Canada during this period, the music performed, and the tremendous rise in popularity of guitar, banjo and mandolin groups.

The guitar in the United States was extremely popular during the nineteenth century. By the middle of the century. the publishing of American guitar music had reached its peak. 1 The 1870 Board of Music Trade Cataloque alone

\footnotetext{
1Peter Danner. "The Guitar in 19th Century America: A Lost
} Social Tradition." Soundboard (Fall 1985), p.297. 
listed "726 entries for solo guitar, 2,309 songs with written out guitar accompaniment, and 34 guitar methods,"a and these figures did not include all American publishers or music no longer in print. The public demand for guitar music in Canada and the Uniter 3tates was large enough to support this continuous publishing of guitar music.

The production of guitars was also a lucrative business in the United States. By the end of the century. 78,494 guitars had been manufactured, 3 and a number of these were sold in Canada. At the turn of the century, however. interest in the guitar faded in the United States.

However, by 1902 the guitar had ceased to be a part of the musical mainstream in most American parlours. Continuity was maintained by small groups of aficionados, but the door had closed on a tradition.

This loss of the American guitar tradition directly influenced the guitar in Canada, and by Wurld War I there were very few references to the instrument being played or taught in the country. For over sixty years prior to that time, however, evidence will show that th guitar was taught

aDanner. "The Guitar in 19th Century America." p.29?.

Ibjd.. p.297.

Ibjd.. p.297. 
and performed across Canada very much in the tradition of the American guitar.

\section{I}

BRITISH COLUMBIA

Victoria had one of the most active known guitar circles in Canada during the second half of the nineteenth century. Much of this was centered around the city's small German community which formed a charal group in 1861 , the first known German musical society in Canada.s Many of these Germans arrived in Vuctoria along with over 20,000 other immigrants during the gold rush in 1858, resulting in the formztion of a city with a wide variety of ethnic backgrounds. The German society encouraged many of these other ethnic groups to attend their concerts.

The Singverein under its musical leader Professor Zinke became a strong community force as it attracted many non-German residents to its varied activities.6

SKallmann. Music in Canada. p.149.

Ibid... p. ${ }^{163}$. 
This group staged many concerts during its existence. As with the majority of concerts in Canada during the nineteenth century, each featured a variety of performers and levels of taient.

Concerts, other than oratorio and opera performances, were not yet specialized into the choral, orchestral, chamber, and solo types that we know today. The majority of musical organizations were choirs: instrumentalists were assembled hurriedly for each concert. Most concerts, in fact, displayed all the musical talent that happened to be available at the mow.ent.?

A German singer and guitarist by the name of $\mathrm{Mr}$. A. Hof fman was a member of "Germania Singverein," and performed both vocal and guitar solos during concerts.

1860

Ballad - "The Lonely Watcher" (Croal)

Ballad - "Then You'll Remember Me," from Bohemian Girl (Balfe)

1862 Grand duet for guitar and banjo by Messrs. Hof fman and Raymond

Grand duo - "Softly Sighs the Breeze" "Leise, Leise, Fromme We ise" from Der Freischutz

by Messrs. Hof fman and George

1862 Second Grand Concert - Victoria Theatre Guitar solo - "Spanish Rondo" (Pique)

by Mr. Hof fman

Grand duet - "Good Night, Love" from Sonnambula (Bellini)

TKallmann. Music in Canada, p.107. 
by $A$. Hof fman and $R$. Georgee

A review of the 1862 colicert stated, "Messrs. Hof fman and George gave a grod account of themselves in several ballads." It is not known whether Hoffman sang these ballads or played them on the guitar. George was a flautist, so it is very possible he played the melodies on the flute, and Hof fman provided a chordal accompaniment with the guitar.

The repertoire performed included an interesting mixture of melodies from popular German and Italian operas (Der Freischutz and La Sonnambula) and popular American songs ("The Lonely Watcher"). Arrangements of these melodies could be found in the majority of American songbooks published auring the nineteenth century.

The rise in popularity of the guitar in America coincided with a craze for Italian melody that swept this country in the 1830s replacing an earlier penchant for Irish and Scottish music. ... Every song-book. every method, every catalogue until well after 1870 is filled with songs, arrangements, and variations lifted from such sources: ... "Still So Gently O'er Me Stealing" (from La Sonnambula).10

-Robert Dale McIntosh, A Documentary History of Music in Victoria Vol. I: 1850-1899 (Victoria: University of Victoria Press, 1981). p.25.

I Ibjd. P. 25.

10Danner. "The Guitar in 19th Century America," p.293. 
"The You'll Remember Me" from Bohemian Girl was an especially popular song in the mid-nineteenth century, 12 so it is likely that Hof fman came across an arrangement of the piece in a book for guitar and flute or guitar and voice.

The 1862 concert which included the guitar and banjo duet was a new development in Canadian music history. The banjo was widely used by the American Blacks, but this is one of the first known references to the instrument being played in Canada. Interest in the banjo could have originated from the large number of minstrel shows from the United States, mainiy San Francisco, which appeared in Victoria from 1861 to the turn of the century. It is also possible that the instrument was brought to Victoria by the city's Black community and played in their musical performances. A review of one of these concerts in 1860 stated :

Grand Serenade: The Negroes of Victoria give Col. Baker. of California, a grand serenade. Every conceivable instrument - whether musical or not - was brought into play. 12

It seems likely that both guitars and banjos were a part of this production. Although it is not clear how public interest in the banjo started in Victoria, the instrument

${ }^{11}$ Danner, "The Guitar in 19th Century America," p.293.

${ }^{12}$ McIntosh. Music in Victoria. p.15. 
remained a popular form of entertainment in the city for the remainder of the century.

After 1862, there are no further references to $\mathrm{Mr}$. Hoffman playing solo guitar, as he formed a duet with a Mr. Charles Hegele, also a member of "Germania Singverein." The duo performed many numbers during concerts sponsored by the choir. Examples of these follow:

1863 Victoria Theatre
Grand Concert for the complimentary benefit
to Belle Divine
Guitar Duet - "Dawn of Day" (St. Clair)13 1863 Grand Concert Guitar Duet - "Helen Waltz" (Pique)14

1864 Grand Concert for Band Fund "Georgina Schottische"18

These are the only concerts for which there are known listings of the pieces performed by the guitar duo, although the guitarists played at numerous other concerts. The titles from their repertoire that are known today, however, indicate an interesting transition from Hof fman's earlier concerts. All of the pieces performed by the duo were either American popular songs or were composed in Victoria.

\footnotetext{
2McIntosh, Music in Victoria. p.31.

14 Ibid.. p. 32 .

${ }^{28}$ Ibid. . p. 37.
} 
influenced by the music south of the border. There were no pieces by European composers.

St. Clair, the composer or transcriber of the "Dawn of Day" played by Hof fman and Hegele, "was the conductor of "Germania Singverein" during this period, and also organist at St. Andrew Church. Upon his arrival in Victoria in 1863. St. Clair published the following announcement:

To the musical public!: The undersigned, intending to locate permanently in this city, for the exercise of his profession. would respectfully of fer his services to the public as a Professor of music. Lessons given upon the pianoforte, violin, guitar and 'cordeon. together with instruction in vocalization and the French language. To all them who may honour him with their patronage he promises the most careful supervision and attention. Pupils who are somewhat advanced are preferred.16

The "Dawn of Day" piece could have been an original composition by St. Clair, or a transcription for two guitars from an American piece of the same name. There is a listing in the 1870 American Board of Trade Cataloque of a piece with this title by a composer named Dressler. St. Clair's knowledge of the instrument and musical background would have enabled him to have easily composed a second guitar part.

16McIntosh. Music in Victoria, p.26. 
It is probable that both the "Helen Waltz" and the guitar solo played by Hoffman in 1862 ("Spanish Rondo") were written by the same $E$. Pique who lived and taught music in Victoria during that time.

E. Pique, having been leader and principal bass singer in some of the best churches of San Francisco and other cities intends to form a clasis for teaching the rudiments of Singing in connection with the teaching of sacred music. if a sufficient number could be obtained. Prof. P. also teaches the guitar, violin and piano, on a very easy method, to be acquired in a very short time.17

The "Spanish Rondo" appears to have been an original composition by Pique, but unfortunately has been lost over the years. It is not known if the "Helen Waltz" duet was an original piece written by Pique, or a transcription of a solo work for two guitars. Again, there are listings of pieces with similar titles in the American trade catalogue. Having lived in San Francisco, Pique would have been exposed to the latest American guitar music being published and performed. Still, one can conclude that there was a surprising amount of composing and transcribing for the gujtar in Victoria in the late nineteenth century, and that the titles, and perhaps even the music itself, of pieces composed were influenced by American popular songs written during the same period.

27McIntosh, Music in Victoria, p.8. 
Mr. J. Silversmith, the principal of a private select School in Victoria for the children of Jewish parents, was also a guitarist, but it is not known where he obtained his musical training. He offered private tuition on the instrument at the institution in 1859 and performed the occasional guitar piece during concerts. Despite having a music degree. Silversmith did not appear to have been a particularly accomplished musician, and received poor reviews of his performances. A concert in 1859 brought the following letter to the editor of the local paper:

Letter to the editor re: Philharmonic Society Concert. In this, the performance of a violin solo by my friend Mr. J. Silversmith, MusDoc, is dispatched with these words. "then followed a violin solo. of which the less is said the better," or to that effect, followed by some disparaging remarks on a guitar accompaniment by Mr. S. to a song by Mr. Bushby.18

Advertisements by two other guitar teachers appeared in the city during the $1880 \mathrm{~s}$. Professor Schaffer, the conductor of "Germania Singverein" in 1875, offered to teach the guitar "at the residence of pupils, sch-ols, or at his rooms" in 1873,19 and a Mrs. J.B. Henderson taught advanced students of the instrument in 1878. Nothing is known of their musical backgrounds.

10McIntosh. Music in Victoria. p.11.

19 Ibid., P. 64. 
The final decade of the century saw the popularity of guitar. mandolin and banjo groups in Victoria. These musical combinations had already become an established part of American culture by this time. In his book. History of Popular Music in America. Sigmund Spaeth places the existence of the guitar within American society in the late nineteenth century:

On the side of the social graces, the ' 80 's developed the practice of the mandolin, banjo and guitar in the American home, the appearance of the bicycle in the streets, the founding of the United States Lawn Tennis Association and the original Life Magazine.zo

By the end of the century, these instruments reached a peak in their popularity in the United States, with the manufacturing of 78.389 mandolins and mandolas. 78.494 guitars and 18,521 banjos.a1 Musical instruction. compositions and performances in Victoria reflected the presence of this trend in Canada as well.

A Victoria charity concert in 1891 featured a medley played by guitars and banjos, and the Aeoilian String Orchestra played at the Sons of Erin Concert in 1895. This ol chestra was comprised of a violinist. three mandolinists.

205igmund Spaeth, History of Popular Music in America (New York: Random House, 1948), p.212.

21Peter Danner. "The Guitar in 19th Century America: A Lost Social Tradition." Soundboard (Fall 1985), p.297. 
and four guitarists, all of whom were women.22 A group calling themselves "The Citharas" played two numbers in the James Bay Athletic Association Concert in 1894. This group was made up of two mandolins, one banjo, and two guitars, and their pieces were entitled "March Iaeal" (Harris) and "Te Volvi a Ver" (Estrada). 23

A Victoria composer by the name of Jack Hanington composed an operetta called "Arcady" at the turn of the century, using a group of guitars and mandolins to accompany the chorus in one number. A performance in 1902 brought this response in The Colonist:

The serenade of the male haymakers in the third act. accompanied by mandolins and guitars, both chorus and instrumentalists being behind the scenes was, perhaps, the best number of the evening. 24

Musical instruction in Victoria during the end of the nineteenth century also reflected popular trends, with instruction being offered on guitar, banjo and mandolin. Mr. Victor Austin and the Victoria School of Music expanded their curriculum to cater to the public's tastes. When Mr. Austin started his own conservatory in 1898, he employed

22McIntosh. Music in Victoria. p.180.

23 Ibid. , p.175.

24The Colonist (Victoria), 2 November 1902. p.3. 
Miss Christie, guitarist in the Aeolian String Orchestra, to teach these instruments.as

The guitar and mandolin clubs formed at the turn of the century were popular in other parts of the province as well. The small community of Nanaimo, located on Vancouver Island. had such a group.

\begin{abstract}
About the turn of the century several women playing mandolins and guitars formed themselves into an instrumental group which was the basis of the first women's musical club of the town. 26
\end{abstract}

There are accounts of groups of bachelors near Chemainus on Vancouver Island using the guitar, among other instruments, during their parties. A photograph of one such festivity (see Figure III:1) shows a wide assortment of instruments being played. Likely, any instrument played by the men would be included in the band, the guitar probably being a common chnice due to its chordal nature. Simple chords would be used to accompany their songs, many of which were composed by the men themselves.27

25McIntosh. Music in Victoria. p.181. 26Sal isbury, p. 40 .

2>Patrick A. Dunae, Gentlemen Emigrants (Vancouver: Douglas \& McIntyre. 1981), p.140. 
FIGURE III: 1 20

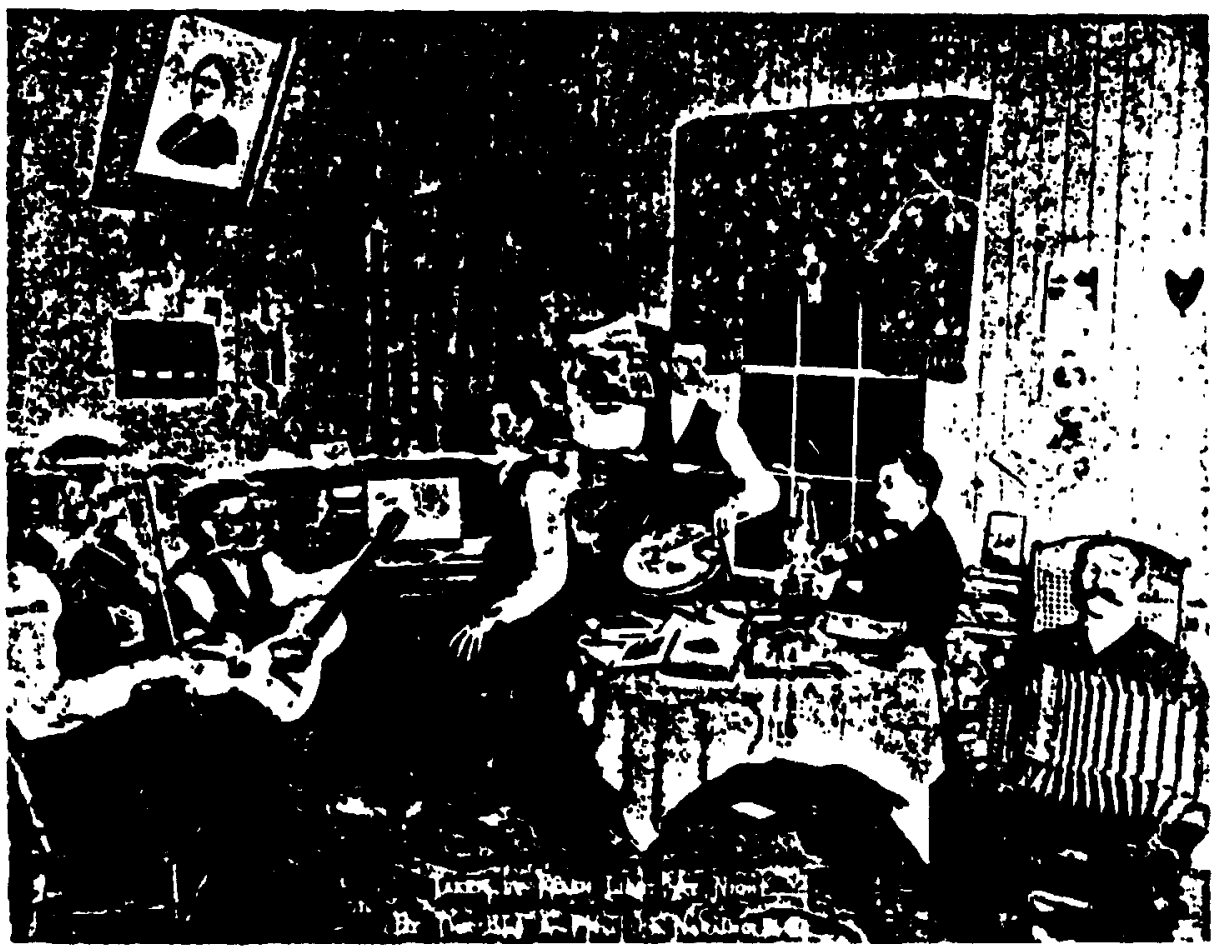

(Prouncial Archives of Bntush Columbia)

Bachelors' party near Chemainus, Vancouver Island, New Year's Eve, 1892

20Dunae, Gentlemen Emigrants. p.139. 
Most of the known references to the existence of the guitar in nineteenth century British Columbia indicate that Victoria had the most active guitar circle in the province at that time. Oni reason for this apparent conclusion would be that references to music in Victoria are easily accessible due to their thorough documentation by Robert McIntosh. Another consideration would be the fact that Victoria was incorporated into a city in 1858, much earlier than Vancouver (1885), and its larger population could support touring groups and organized concerts. The guitar was likely a part of musical life in Vancouver as well during the last decade of the century.

It will be shown that the musical trend seen in British Columbia during the second half of the nineteenth century and first two decades of the twentieth century was similar to that found across the rest of the country during the same time period. The musical influence from the United States during this time was not limited to British Columbia. 
I I I

THE PRAIRIE PROVINCES

While reforences to the guitar can be found in nineteenth century prairie settlements, thoee available indicate the instrument's primary use as a means of accompaniment to vocal music. Mantolin, banjo and guitar groups were also a popular form of entertainment.

In 1888, a guitar and bagpipes provided the music at a fund raising event for a new school bell in Edmonton.20 Guitar accompaniment for singing was used at a social at Horse Hills in 1895,30 and also with a mandolin and banjo at a garden party in 1896 .

A garden party was given last evening by the young people's branch of the Ladies' Hospital Aid Society at the residence and grounds of $\mathrm{Mr}$. and Mrs. J.A. MacDougall.... Miss Calvert and Mssrs. Plowright and Springett gave a number of vocal selections with mandolin, guitar and banjo accompaniment, which were highly appreciated. 31

${ }^{2}$ Edmonton Bulletin, 5 January 1888, p.4.

30Edmonton Bulletin, 30 December 1895, p.4.

${ }^{31}$ Edmonton Bulletin, 16 ,Tuly 1896, p.4. 
The guitar was also a part of the Fort Saskatchewan Mounted Police Concert in 1898.32 The only reference to the guitar being played as a solo instrument dates from 1898, when an outline of the programme at an Edmonton congregational social included an organ voluntary, guitar solo, choir and local soloists. ${ }^{33}$ Unfortunately, it is not known what piece was played and by whom.

As in Pritish Columbia, groups of bachelors from England used the guitar along with other instruments to entertain themselves during parties.

\begin{abstract}
References to feeling isolated and lonely are among the most striking features in the emigrants' diaries and journals and $; n$ the letters t:ey sent home to England. The same feelings also underlay the songs that English bachelors in the West sang to amuse themselves. One of the most popular songs was entitled "Life in a Prairie Shack." 34
\end{abstract}

This tune was first heard in the 1880 s in Saskatchewan and gradually became popular in cther parts of the prairies. It was sung to the tune of "Life on an Ocean Wave."

Oh, it's life in a prairie shack.

When the rain begins to fall;

It drips through the mud on the roof,

And the wind comes through the wall.

\footnotetext{
3aEdmonton Bulletin, 27 January 1898, p.3.

${ }^{3}$ Edmonton Bulletin, 3 March 1898, p. 4.

34Dunae. Gentlemen Emigrants. p.140.
} 
And the tenderfoot curses his luck

And feebly murmurs "Ah!

The blooming country' 3 a fraud.

And I want to go home to my ma." so

The earliest known reference to the guitar in Winnipeg dates from 1896 with the arrival of the Ukrainians in the city. It was used as a means of accompaniment to singing and dancing, and was also popular in Ukrainian string orchestras isee figure III:2). By the end of World War I, over eighty of these orchestras were organized in Ukrainian Farmer-Labor Temples across Canada. 36

String orchestras, composed of violins, mandolins. guitars and sometimes a cello. a piano accordian. or a piano are almost as popular as choirs but, owing to. the lack of qualified teachers and conductors, they have not reached the high standard of the latter. 37

Other references to the guitar in early winnipeg include a May 31. 1906 recital at the YMCA Auditorium which featured the students of Miss Ethel Lawson. The guitar was used to accompany one student who sang a "French Canadian Melody. " 30

35Dunae, Gentlemen Emigrants, p.140.

36Michael H. Marunchak. The Ukrainian Canadians: A History (Winnipeg: Ukrainian Free Academy of Sciences, 1970). p.455.

$3>$ Paul Yuzyk. The Ukrainians in Manitoba (Toronto: University of Toronto Press. 19531. D.166.

${ }^{30}$ National Archives of Canada (hereafter NAC). MusaC Division. Winnipeg Concert Programmes. 1906. 


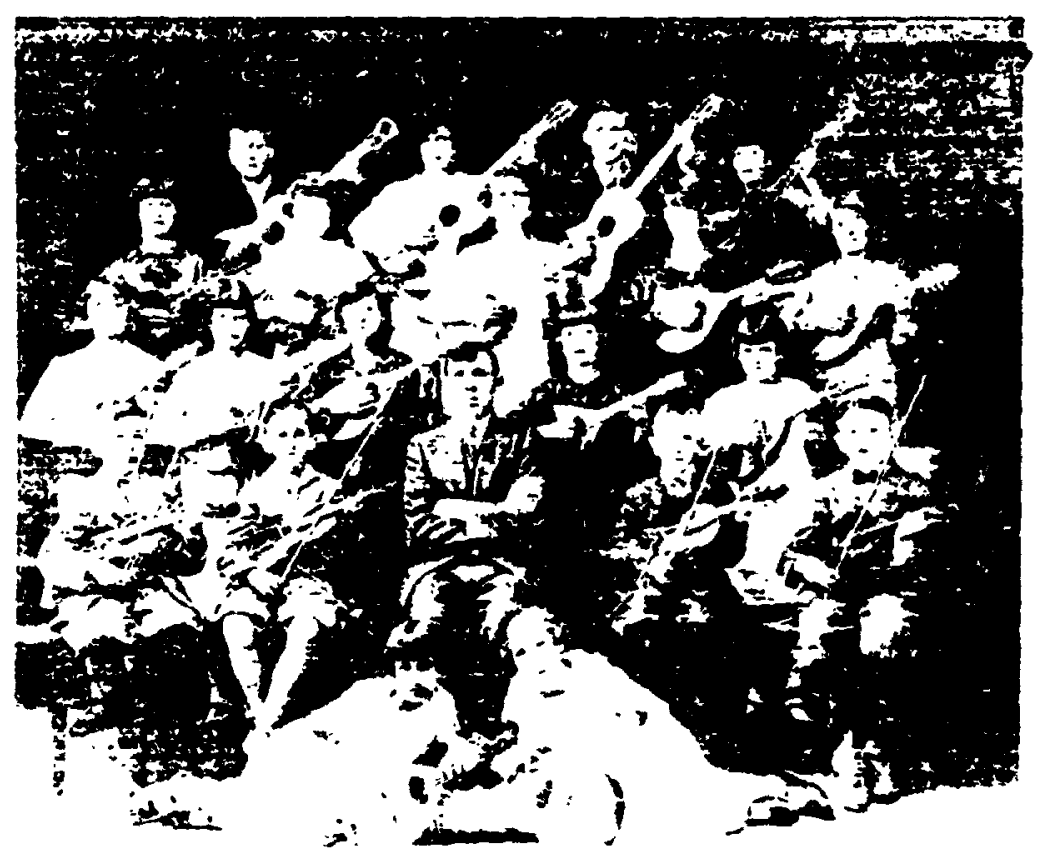

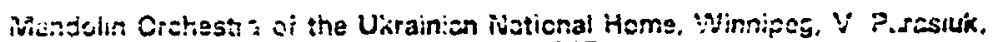
senducter, 1227

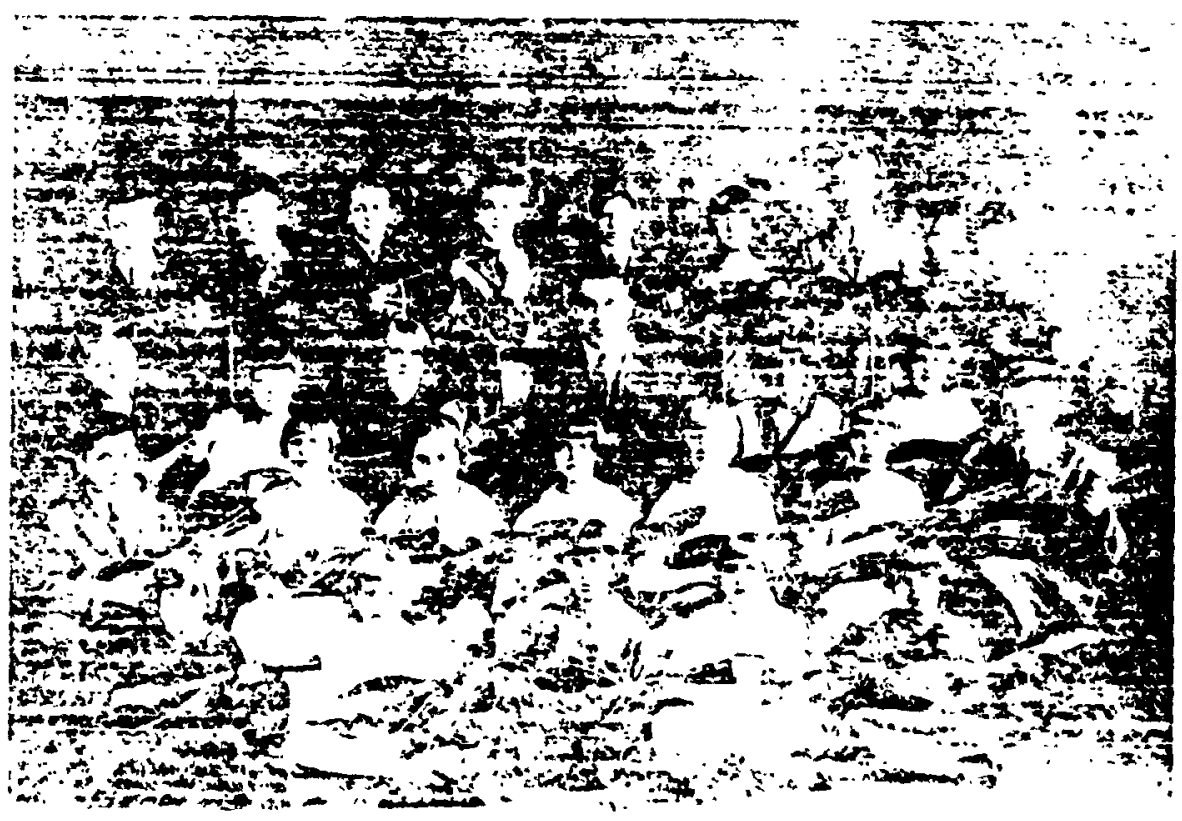

39Marunchak. The Ukrainian Canadians. p.387. 


\section{ONTARIO}

Toronto was the major centre of guitar activity in Ontario during the late nineteenth century, although the instrument did not become popular unt 1 l the late 1880 s. Until that time, references point to the existence of the piano, band and orchestral instruments in the city. It is likely that the rise of interest in the guitar was directly related to the large influx of immigs ants to Toronto toward the end of the century.

Guitars and strings were advertised in Toronto city directories periodicals and newspapers as early as 1851. A \& S Nordheimer sold guitar strings thet year.40 Small \& Addison advertised guitars for sale $3 \mathrm{r} 1856.41$ and E.B. Butland sold guitars ranging in price from $\$ 3$ to $\$ 10$ in 1870.42 In 1862. Henry Benary made it known that he imported genuine Italian strings, which would have been made from gut with silk wound basses. 43

$40 \mathrm{Glabe}$ and Mail. 14 August 1851, p.2.

${ }^{41}$ Canadian Musical Review I. No.1 (1 May 1856), p.32.

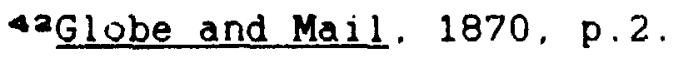

${ }^{43}$ Toronto City Directory, 1862-63, p.68. 
These guitars sold in Toronto were imported from the United states, where factories were turning out low cost instruments to meet the large demand across the continent. The first American census to 1 ist manufacturing statistics reported "that 300 guitars were produced in 1850 in Pennsylvania (presumably Martin's workshop)."44 This number increased rapidly as technology improved and new factories opened. Canadians could purchase these instruments from importers or directly from American mail order houses through catalogues. For example. in 1888. Claxton's Music Store in Toronto advertised. "Guitars for sale. Guitars neatly repaired. Catalogue available."45 Catalogues featured the most current music and guitars available in the United States.

There is only one known reference to the construction of guitars in Canada during the late nireteenth ceitury. A company named R.S. Williams \& Sons was established in 1854 in Hamilton, and opened branches in Winnipeg. Calgary, Montreal and England by the end of the century.46 Although the company specialized in the construction of pianos, it

44Peter Danner. "Guitar." The New Grove Directory of Ainerican Music ed. Wiley Hitchcock \& Stanley Sadie (London: MacMillan Press. 1986). p. 297.

${ }^{45}$ The Musical Journal II. No.9 (November 1888), p.34.

${ }^{46}$ Helmut Kallmann et al. Encyclopedia of Music in Canada. "R.S. Williams \& Sons" (Toronto: University of Toronto Press. 1981), p.1002. 
did make stringed instruments such as the guitar banjo and mandolin. Unfortunately, it is not known how many of these instruments were produced or the cities in which the majority of them were sold.

Although most instruments were purchased from the United states. strings tended to be imported from Europe during the late nineteenth century. Until 1890, factorymade American guitars used gut rtrings, after which time steel strings were manufactured.47 It is possible that high quality gut strings were not produced or easily available in the United States. creating a demand for European strings.

In spite of this evidence of guitars being present in Toronto, no mention is made of the instrument being performed in concerts or being taught unt 11 the end of the century. Advertisements were placed by four guitar teachers in the 1890 edition of The Music Journal:

1. Prof. de Lima - Teaching of the violin, guitar. and mandolin a specialty.

2. Lloyd $\mathrm{N}$. Watkins - Teacher of the banzo. guitar. mandolin and zither.

3. G.H. Ozburn - Teacher of the banjo and guitar. Also teaches at the Toronto College of Music.

4. Wm. J. Parkes48

47Kallmann, ed., "R.S. Wllliams \& Sons." p.297.

${ }^{40}$ The Music Journal IV. No. 3 (March 1890), p.23. 
Unfortunateiy, nothing is known of the backgrounds of these teachers, although Prof. de Lima's name implies a Spanish or Latin American heritage. The combinations of instruments taught, however, indicate the American influences. As in the western provinces, guitar, banjo and mandolin clubs became a part of the Toronto musical culture as well. Touring clubs from the United States often performed in Toronto. Following is a review of one such concert in 1890 :

The Boston Banjo. Mandol in and Guitar $\mathrm{Club}$ gave a novel entertainment at the Association Hall, consisting of ensemble and solo playing. which was a revelation to many who looked upon these instruments as merely fit for sentimental, love-sick maidens and flat-footed dusky minstrel showmen. 49

A number of advertisements by guitar, mandolin and banjo teachers appear until 1920 in Toronto musical journals, at which point the popularity of these instruments waned. While the guitar did not disappear completely in Toronto, it was no longer at the forefront of musical activity.

This trend can also be seen in other cities in Ontario where the guitar was taught during the late nineteenth century. There was a fair amount of interest in the 
instrument in ottawa during this time. The city directories indicate the guitar was a popular instrument in educational institutions for young ladies. The Convent of Ottawa, a boarding school run by the Grey Sisters, taught guitar for $\$ 30$ per term. An 1869 advertisement for the school included the following paragraph:

Every facility is given for the study of Music. so that students can rapidly attain the highest degree of success therein. Musical instruments in use are the Harp, Plano, Guitar. Melodian. Organ. etc.so

The Congregation de Notre Dame for young ladies also taught guitar. charging a fee of $\$ 20$ per term. 52 As in Toronto. interest in the guitar in Ottawa disappeared in the early twentieth century, and instruction was no longer offered on the instrument.

The guitar was also a popular instrument during the late nineteenth century in smaller cities such as Guelph. A Guelph school concert in 1894 featured a guitar and flute duet, 52 and entertairment at a function the same year was provided by a trio made up of two guitars and a mandolin. 53 These performers could have been a part of a Mandolin and

So ottawa City Directory, 1869, p.1.

32 Ottawa City Directory. 1877, p.175.

52 Evening Mercury ('Juel ph), 17 January 1894, p.1.

${ }^{5}$ Evening Mercury. 24 March 1894, p.1. 
Guitar Ciub in Guelph active at that time.s4 Banjos, guitars and mandolins were available in Guelph at that time from C.W. Kelly's Music Store, who imported these instruments from Boston and New York. ${ }^{\circ}$ The guitar activity in Ontario, even in a small city such as Guelph. clearly indicates the American influence.

QUEBEC

The purchase of guitars and music in Québec during the second half of the nineteenth century was similar to that in Ontario. Instruments and strings were imported from the United States by people such as Arthur Lavigne of Québec Citys6 in 1875 and J.G. Yin of Montreal from 1900-1903 s?. or could be chosen from catalogues and ordered directly from American music houses.

54Evening Mercury, 5 March 1894, p.1.

soguelph Herald Illustrated. December 1895.

s6 Quebec and Levis Directory, 1875, p.86.

sMontreal City Directory, 1900 and 1903. 
"Guitares" for sale

Washburn Model 1897

Catalogue - Lyon \& Healy, Chicagose

In the January. 1897 edition of L'Art Musical, this announcement appeared: "Une guitare du prix de $\$ 225$. fabriquée par mm. J.C. Haynes \& Co.. est exposée à Pittsburg." These advertisements show the superior quality of American instruments available to residents of Québec at this time.

During the latter part of the nineteenth century and early decades of the twentieth, there were many companies in America making flat-top guitars similar in shape and size to those built by Martin. Martin's most serious rival as a maker of high-quality guitars was the Washburn Company. founded in the $1890 \mathrm{~s}$ by George Washburn Lyon of the Lyon \& Healy Company. From its founding through the 1920 s and 1930s. Washburn made a comparatively small number of $f$ inely constructed instruments which are now rare and highly prized.59

Even in French Canada, influences tended to come from south of the border rather than from Europe during this period, although music was also obtained from France and Eng land.

A. \& J. Vezina

Marchands de Musique, etc., etc.

ont l'honneur d'informer le publac en general qu'ils ont en main un assortiment considérable d'instruments

sol.Art Musical. October 1896. p.52.

59Tom and Mary Anne Evans, Guitars: From the Renaissance to Rock (New York: Paddington Press, 1977), p.223. 


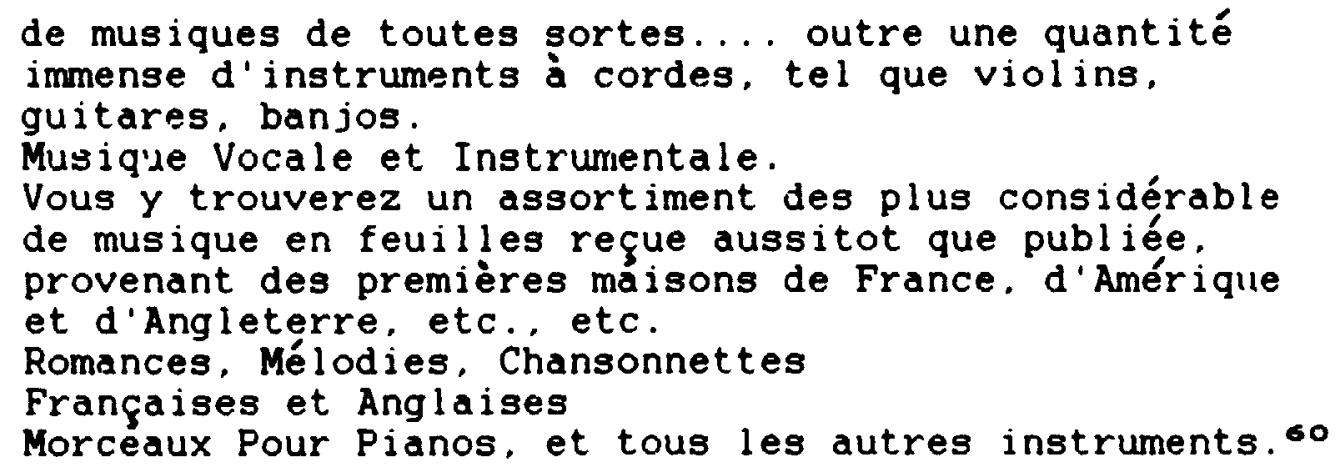

It is interesting to note the sale of banjos, guitars and American music by Vezina. Guitar, mandolin and banjo groups were popular in Québec during the late nineteenth century, reflected in the sales of these instruments, the lessons available, and concerts performed.

In 1896. T.A. Simpson of Montreal offered lessons on the guitar, violin, banjo and mandolin.61 A Monument National Concert in the following year featured "Les Freres de la cóté." a five act opera. In this performance, the "quatuor national." an ensemble consisting of mandolins and guitars, played a number after the prologue.6a It is likely this ensemble performed other concerts in Québec, but further evidence must be uncovered to verify this.

${ }^{60}$ Québec and Levis Directory, 1872-73. p.189.

61 Musical Redbook of Montreal (Montreal, 1896), p.150.

${ }^{62} \mathrm{NAC}$. Music Division. Montreal Concert Programmes, $1896^{\circ}$. 
The popularity of the guitar in Quebec appears to have declined after the turn of the century except for a fow sparse references to its existence. This loss of interest in the instrument occurred more than twenty-five years after the article from the 1875 edition of Le Canada Musical, discussed in chapter two, which claimed, "aujour'hui on ne les [la guitare et la mandoline] entend plus."6s

\section{VI}

THE ATLANTIC PROVINCES

Guitar teachers, music and instruments were also available in the Atlartic provinces during the second half of the nineteenth century, largely in Halifax. In 1858 , Senor Louis Casseres of Halifax made it known that "he had four hours a week free and would accept a pupil for piano, flute, guitar organ or singing." 64 Casseres" qualifications were impressive; he was the organist at $5 t$ Paul's and had been pianjst to the Earl and Countejs of

- 3e Canada Musical. "La Musique," Vol.II, No.8 (1 December 1875), P.118.

"Phillis R. Blakeley, "Music in Nova Scotia 1605-1867." The Dalhousie Review 31 (Summer/Autumn 1951), p.226. 
Mulgrave, although his background in guitar is not known. His use of the title "señor" indicates that he may have had a Spanish background.

Residents in towns where there were no music stores had to order guitars. music and supplies from American companies advertising in city directories. This seemed to be particularly the case in New Brunswick. Italian, German, French and English gut guitar strings were for sale by Edward Baak of New York in 1865, and Frith \& Co. advertised guitars, cases, American and foreign music, and Italian, German and English strings, ail available through majl order. The absence of advertisements for American gut strings supports the theory that these were not readily available from the United States. The guitirs and music. however, were American.

In the late 1860s, R.T. Muir of Halifax sold a catalrque of the newest sheet music and music books available to his clients. In the appendix to this publication, the following paragraph appeared:

Winner's Perfect Guide for the Guitar Designed to lead to a knowledge for the art of performing on a guitar. without the aid of a teacher and presenting for practice and recreation 150 select pieces of music for that instrument.65 
This guitar method is listed for the selling price of $\$ .75$ in the American Board of Trade Citaloque of 1870 . Peter Danner explores its repertoire in his article, "The Guitar in 19th Century America: A Lost Social Tradition:"

The most striking feature of such later methods as... Septimus Winner's "Easy System for the Guitar" (1866) ... is their conservatism. While the mainstream of popular music moved away from the simple strophic and binary forms in favor of the verse/chorus format and began to experiment with a richer harmonic palette (partly the result of Wagner's tremendous influence at the time), the misic found in these tutors tends to be the same old repertoire carried over from the 1830 s.66

Whatever the repertoire, method books such as "Winner's Perfect Guide for the Guitar" would have been useful in isolated areas of the Atlantic provinces where there were no guitar teachers.

Another such American guitar song book dates from 1907. and was a part of the J. Hollis Lindsay Music Collection. Isindsay was a blind pianist who attended the Halifax School for the $\mathrm{Bl}$ ind in the early $1900 \mathrm{~s}$ before moving to the United States. It is not known whether he played the guitar, but the book was a part of his collection, discovered in the attic of the school in 1983.

"Danner, "THe Guitar in 19th Century America," p.296. 
It would appear that the guitar was not a popular instrument in Newfoundland during the nineteenth century. One of the only references discovered dates from 1857. "Chisholm's Book Store of 1857 was one of the older shops and sold sheet music, violins, guitars, and flutes."67 The guitar was not widely used as a folk instrument until the introduction of steel strings. so the absence of the instrument in a province so rich in folk music and instruments is not surprising.

67Paul Woodford. We Love the Place, O Lord: A History of the Written Musical Tradition of Newfoundland and Labrador to 1949 (St. John's: Creative Publ., 1968), p.194. 
VII

CONCLUSION

\begin{abstract}
Evidence shows that the influences of the American guitar tradition in the late nineteenth century on Canada were felt across the country. The instruments and music played, for the most part, came from south of the border. The popularity of guitar. banjo and mandolin groups in the United States was also duplicated in Canada.
\end{abstract}

Table III:1 lists the plucked stringed instruments which were known to have been taught and performed across Canada during this time. With the exception of the Atlantic provinces, the guitar, banjo and mandolin were ferformed and/or taught in each of the provinces. More evidence needs to be uncovered to krow details of the backgrounds of the musicians playirg these instruments. but there is a definite trend in the popularity of the guitar, banjo and mandolin. During the :ate nineteentr, century there were seven known organized ensembles in Canacla made up of the guitar and the banjo and/or mandolin. New evidence would likely reveal many more such groups, particularly in universities.

A list of all krown titles of guitar music performed in Canada during the period discussed is given in talle III:2. Again, the list establishes the popularity of guitar, banjo and mandolin music across the country. The music for these 
TABLE II I : 1

GUITAR TEACHERS AND PERFORMERS IN CANADA

FROM 1850 TO 1920

NAME

Mr. Hof fman

Mr. Hegele

Mr. Raymond

Mr. St. Clair

Mr. Pique

J. Silvermith

Prof. Schaffer

Mrs. Henderson

Miss Christie

Prof. de Lima

Lloyd Watkins

G.H. Ozburn

Wh. Parkes

T.A. Simpson

Quatuor National

Louis Casseres

Aeolian String

Orchestra

The Citharas

Nanaimo Group

Ukrainian String

Orchestra
CITY

Victoria

Victoria

Victoria

Victoria

Victoria

Victoria

Victoria

Victoria

Victoria

Toronto

Toronto

Toronto

Toronto

Montreal

Montreal

Hal ifax

Victoria

Victoria

Nanaimo

Winnipeg
INSTRUMENTS TAUGHT/PERFORMED

GUITAR

BANJO

MANDOLIN 
TABLE III : 2

GUITAR MUSIC PERFORMED IN CANADA FROM 1850 TO 1920

\begin{tabular}{|c|c|c|c|}
\hline TITLE OF PIECE & DATE & NATIONALITY & INSTRUMENTATION \\
\hline "The Lonely Watcher" & 1860 & American & Guitar \\
\hline $\begin{array}{l}\text { "Then You } 11 \\
\text { Remember Me" }\end{array}$ & 1860 & Italıar & Guitar \\
\hline $\begin{array}{l}\text { "Softly Sighs the } \\
\text { Breeze" }\end{array}$ & 1862 & Unknown & Guitar. Flute \\
\hline $\begin{array}{l}\text { "Leise, Lelse, } \\
\text { Fromme We ise" }\end{array}$ & 1862 & German & Gustar. Flute \\
\hline "Spanish Rorido" & 1862 & Canadian & Guitar \\
\hline "Good Night. Love" & 1862 & Italian & Guitar. Flute \\
\hline "Dawn of Day" & 1863 & Canadlan & Guitar Duet \\
\hline "Helen Waltz" & 1863 & Canadian & Guitar Duet \\
\hline "Georguna Schottische" & 1864 & American (?) & Guitar Duet \\
\hline "March Ideal" & 1894 & Aner ican (?) & $\begin{array}{l}\text { Guitar. Banjo. } \\
\text { Mandol in }\end{array}$ \\
\hline "Te Volvi a Ver" & 1894 & Unknown & $\begin{array}{l}\text { Guitar, Banjo } \\
\text { Mandolin }\end{array}$ \\
\hline $\begin{array}{l}\text { French Canadian } \\
\text { Melody }\end{array}$ & 1906 & Canadian & Guitar, Volce \\
\hline $\begin{array}{l}\text { "Les Frères de la } \\
\text { côté" }\end{array}$ & 1897 & Canadian & Guitar. Mandol in \\
\hline "Arcady" & 1902 & Canadian & Guitar. Mandol in \\
\hline
\end{tabular}


ensembles came from American songbooks. This table also indicates that music for the guitar came from the United States and not from Europe. A surprising amount of music was also composed in Canada for the instrument.

It appears evident that the guitar in Canada was influenced by the American guitar. but the question remains as to why this happened. Immigrants to Canada were arriving from Europe and many other parts of the world, so why did they adopt an American musical tradition and not maintain their own?

Helmut kallmann puts forth a theory as to why many American songs were played in Canada's western provinces.

The conditions of pioneer life on the prairies were not conducive to the preservation of folk song. chiefly because settlements were too isolated and settlers were of different national origins. ... Most local-colour songs were actually imported from the United States' reglons to the south. which had been settled earlier.6o

Another reason for the adoption of Amerlcan culture would be the avallabllity of instruments and music. Catalogues and mall-order houses made these accessible in even the most isolated regions of Canada. Mass production resulted in guitars, banjos and mandolins and their music being sold at an affordable cost.

Touring guitar, banjo and mandolin groups from the United States would have exposed Canadians to ensembles of

6 Music in Canada. p.159. 
this nature. creating an interest in Canada to learn these instruments. Certainly the formation of similar groups in Cariada provided settlers with an inexpensive means of entertainment and social activity. The instruments were also farly easy on which to learn the basic techniques.

Although the guitar became a popular instrument in Canada during the late nineteenth century. much of its European tradition as being an elite women's instrument was maintained across the country. Part of the explanation for this could be that the guitar was considered to be an Instrument of the upper-class women in England until the end of the century.

It was always Madam Pratten's lan English guitar teacherl desire to maintain the prestige of the guitar... She dreaded the idea of her instrument becoming in any way vulgarized, and insisted upon it keeping its place exclusively in the gentlewoman's drawing room.69

It could be a result of this English influence that "higher women's academies" such as those in nttawa continued to offer instruction on the instrument unt 11 the end of the century. It is interesting to note that there are fewer references to institutions of fering guitar tuition after the 1860s than in the years prior to this time. Perhaps the English influence was diminishing.

69Evans. Guitars. p.159. 
The guitar did, however, remain largely a women's instrument, although soloists were men. Most of the members of the known string orchestras and guitar ensembles were women, and an increase in numbers of women guitar teachers is found in the late nineteenth century.

By the early years of the twentieth century, the guitar in both Canada and the United States had lost its prominence in musical society.

Dealers at the present time [1900] say that the trade in small instruments of this class lguitars, mandolins and banjosl has been virtually killed off by the automatic musical instruments. $>0$

When the guitar regained popularity in the midtwentieth century, it had developed into numerous different musical styles. Chapter four will examine how one of these styles, the classical guitar, became established across Canada.

70W.L. Hubbard. History of American Music (Toledo: Irving Square, 1908), p.334, quoted in Danner, "The Guitar in 19th Century America." p. 297. 
CHAPTER FOUR

THE FORMATIVE YEARS OF THE CLASSICAL GUITAR IN CANADA $1920-1960$

INTRODUCTION

In the years between the two World wars. guitar activity in Canada was generally limited to styles of gujtar playing imported from the United States, such as folk, jazz. blues and country and western. Gutar and mandolin groups still existed. but had disappeared from the forefront of musical performance. Steel stringed gujtars became very popular across North America after 1920. suitable as folk instruments because of the brighter and louder tone of the steel strings as compared with the traditional gut strings. A description of the 1934 session at the newly-formed Banf School of Fine Arts mentions the guitar being used in this capacity:

But I think the sessions at the 1934 School which will live longest in the memories of those who attended were the classes in folk singing led by Jocelyn Taylor and Wally House. They were both accomplished guitarists and their repertoire of folk songs represented every 
part of North America and many European countries. They were a joy to students and public alike.1

The divisions between the different styles of guitar playing had emerged, divisions which exist to this day. What is now termed the classical guitar predominantly a solo instrument, did not have a following in Canada during the first half of the twentieth century. or. indeed, in many other countries.

This chapter will document the formative years of the classical guitar in Canada. The small number of teachers and aficionados of the instrument who built the foundation for its eventual acceptance in Canada will be discussed. Similarities between the development of the guitar in early Canada. as discussed in chapters two and three of this thesis, and the early classical guitar in Canada will also be explored.

${ }^{2}$ Edward A. Corbett. We have with Us Tonight (Toronto: Ryerson Press. 1957). p.102. 
I I

THE EARLY CLASSICAL GUITAR IN CANADA

Much of the initial interest in the classical guitar in Canada and many other countries in the world was due to the efforts of Spanish guitarist Andrés Segovia (1890-1987). As Graham Wade argues, it was Segovia who brought the instrument into concert halls around the world:

The classical guitar in the twentieth century owes its popularity and esteem primarily to the work of Andrés Segovia. He drew together the divergent strands of the traditions of the guitar. established a repertoire and by the force and sweetness of his personality inspired disciples and audiences with the necessary fervour for an intense pursuit of the instrument's secrets.2

Segovia made his debut in Granada. Spain in 1909 and his first concert tour in 1920 to South America, followed by performances in most countries around the world. Even as late as 1940. however, his manager had difficulty booking concerts for the maestro.

Segovia was regarded for many years as a crusader for a lost cause - a brilliant interpreter on an instrument not worth cultivating, and bound to be one-of-a-kind. ${ }^{3}$

${ }^{2}$ Graham Wade. Traditions of the Classical Guitar (London: John Calder, 1980), p.xi.

3Allan Kozinn. The Guitar: The History, The Music, The players (Toronto: Musson-General. 1984), p.35. 
A major problem with the classical guitar was the poor intonation and tuning associated with gut strings. In 1946. Albert Augustine invented the nylon string which alleviated this problem.

Segovia was not the only international performer between the wars. Agustin Barrios (1885-1944) of Paraguay, Regino Sainz de la Maza of Spain, Migel Llobet (1878-1939) of Spain, and Emilio Pujol (1886-1980) also from Spain, were among guitarists who played concerts in many parts of the world. It was Segovia, however, who brought the instrument to its elevated prominence. A critic from the Observer of London in May of 1970 wrote:

\footnotetext{
Segovia is supremely civilised. He drinks only the purest wines, reads only the rarest literature ... At fifteen Segovia gave his first concert in Granada to an audience composed mainly of the sceptical and the curious. [Segovia said]. "They could not conceive that the Spanish guitar was for anything but flamenco. I have spent a lifetime trying to redeem the guitar from flamenco...."
}

Around the world, this was the civilized height to which Segovia brought the classical guitar. Endeavoring to hav; the instrument accepted as a legitimate concert instrument. he devoted his life to this cause.

\footnotetext{
As quoted in Wade. Traditions of the Classical Guitar. p. 188 .
} 
Through an invitatıon exterided by the Montreal Ladios Morning Musical Club. Segovla performed in Canada for the first time on March 4. 1937. He played a concert at the Ritz Carleton Hotel. Segovia returned numerous times to the city, Including performances at the University of Montreal and in Her Majesty's Theatre st. Denis. The guitarist's first performance in Toronto. by contrast. was not until 1948 when he appeared with the Solway Quartet to perform the Castelnuovo-Tedescu Quntet and several guitar solos.

It was through these appearances and recording technology that Segovia was able to create an interest in the classical gustar in Canada. His recordings were widely known. and television appearances as early as the 1950 s introduced viewers to a relatively unknown technique of guitar performance.

Those Canadians who became interested in the classical guitar and wanted to pursue study of the instrument had many difficulties to overcome. Instruments, strings and music were not available in music stores, recordings were often difficult to obtain. and classical guitar instruction was not offered. Consequently, students of the instrument had to either teach themselves or study in Europe or the Unated States, as well as import any required instruments and music. This situation will be seen more clearly through a 
discussion of the major classical guitar figures in Canada during the $1950 \mathrm{~s}$.

MONTREAL

Aithough Segovia's first Canadian appearance was in Montreal in 1937, there were no known classical guitarists in the city until more than twenty years after that time. Stephen Fentok was one of the first to emerge, and for many years was the major force behind the rise of interest in the classical guitar in that city.

Born in Montreal in 1930. Fentok started his early musical training on the violin. He first heard and loved the sound of the guitar on a soundtrack of one of the numerous American "westerns" shown in Montreal during the 1940s.5 "Country and Western" guitar was one of the most popular styles during that period, a result of American influence.

Spersonal interview with Stephen Fentok, Montreal, October 1989. 
Not interested in singing to a guitar chordal accompaniment. Fentok made the transition to electric guitar, playing everything from "Big Band" to "Dixieland" music. By the age of seventeen. Fentok was playing in all the major clubs in Montreal and doing studio work for the CBC. His first introductior to the Spanish guitar was through a recording of flamenco playing by Carlos Montoya. Fentok also listened to a weekly radio programme from New York City which featured the classical and $f$ amenco guitars. hosted by guitarist Vincente Gomez.

Gomez, though not real'y a classical player being more interested in flamenco, also achieved fame in the forties winen he appeared in a Hollywooc film Blood and Sand. where. " $n$ the elegant company of Tyrone Power and Rita Hayworth, a rendering of "Romance de Amore" delighted the film-going public. 6

"Romance d'Amor" has never last its public appeal. and later became one of Liona Boyd's most proular recordings.

It was Fentok's harmony teacher who introduced him to a recording of Segovia's playing, and Fentok soon obtained his own by writing to the record company in England. In 1951 , Fentok beqan to study the classical guitar with Alexander Bellow in New York City, commuting once a month for two years. He purchased a guitar in the Spanish Music Centre in

'Wade. Traditions of the Clasgical Guitar. p.197. 

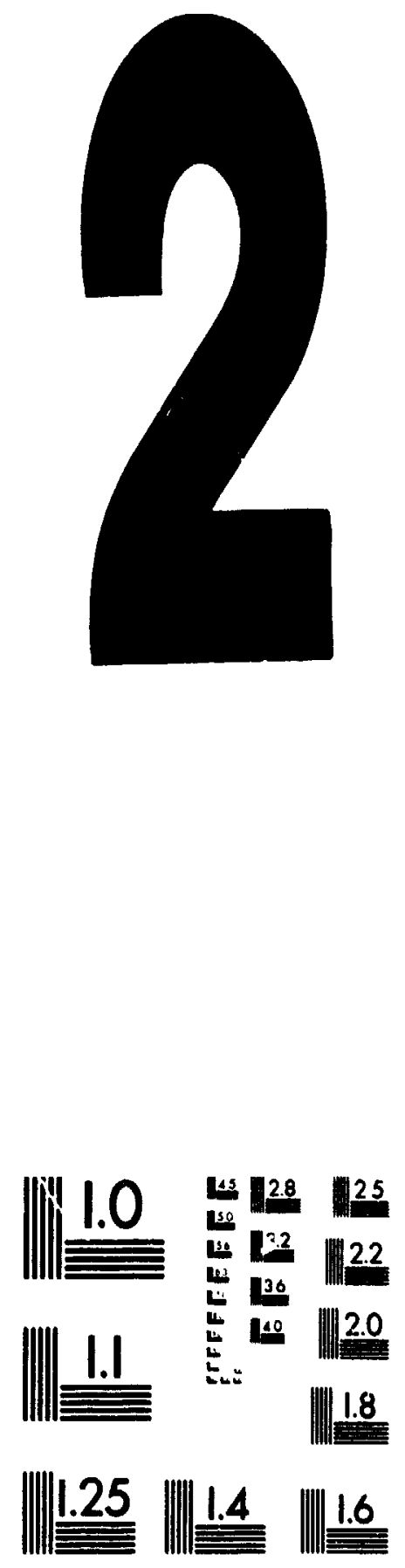

MICAOCOPY RESOLUTION TEST CHART NATIONAL BUREAU OF STANDAROS

STANDARD REFERENCE MATERIAL 10108 (ANSI and ISO TEST CHART No 2) 
New York as classical guitars were not available in Montreal at that time.

Fentok began to introduce classical guitar selections into his work with tremendous response from audiences. On a CBC television show, he accompanied dancers with "Austurias" and "Sevillanas." He also accompanied singers on radio programmes with the classical guitar, alternating with some guitar solos. Fentok can certainly be considered to be Canada's first professional classical guitarist, all other performers during this period being amateurs with other careers.

Gradually Fentok began to convert his students to the classical guitar, ordering strings, instruments and music from the Spanish Music Centre until local stores began to stock adequate supplies. Most of Fentok's early classical guitar students were folk guitarists who wanted to improve their right hand technique and play more than a simple strumming accompaniment to their songs. These folk guitarists did much to help the growth of the classical guitar in Montreal. Fentok maintains. A well-informed group. they supported and attended gujtar concerts as well as attending meetings of a guitar society Fentok formed in the early 1950s. This society did not last, however, as tensions developed between the folk and classical 
as Carcassi studies and end with folk songs until the society's eventual end.

At this time. Fentok decided to pursue further study of the classical guitar and left for Milan and Paris. Having received the London Guitar News and New York Guitar Review for a number of years. Fentok was aware of the most prominent European guitariste and societies of the time. His trip was disappointing, however, when he heard little more than simple Carulli waltzes from many of these players. He found that standards of performance were not much higher than those in North America. At the same time, it was assumed in Canada that one was a much better player if one had studied in Europe.

Fentok did have the opportunity to meet Emilio Pujol on his trip. and returned at a later date to study with the guitarist with the aid of a Canada Council grant. He also studied with Alirio Diaz, the Presti/Lagoya duo, and audited master clases given by Segovia, all of which enabled him to eventually develup a solid teaching methodology of his uwn.

Through study with French guitarists Ida Presti (19241967 ) and Alexander Lagoya (b.1929). Fentok was exposed to the distinct guitar technique of this couple. Presti was a child prodigy who married and formed a duet with Lagoya. a self-taught musician. in 1950. Their technical brilliance 
and exceptional ensemble playing quickly brought them to international fame.

Presti and Lagoya had a different musical approach from that of Segovia. They played Baroque trills and ornaments on two strings instead of the more common single string method. The major difference, however, was in the right hand technique. Rather than using the left side of the nail to produce a sound, the Frencin duo used the right side of the nail. Consequently, hand positions differed between what developed into the Segovia school and the Lagoya school (Presti died in 1967) of playing.

Presti and Lagoya first played in Montreal in 1958. Because Fentok was a wel1-known guitarist in the city. Lagoya had heard of him from Bouchet, a French guitar maker. and contacted him upon his arrival in Montreal, thus beginning Fentok's association with the duo. The duo returned to the city each year, teaching at "Jeunesses Musjcales du Canada" and making Montreal their second home.

Quebec embraced the duo. The lack of a language barrser contributed to this alliance. Their right hand technique had a tremendous impact on guitarists in Quebec. and the term "disciple de Lagoya" was adopted by converts of the technique. Fentok spent two summers in Nice learning their technique, but found he was not a total convert as he 
had a number of reservations about its merits. He taught both methods, however - off the right at "L'Ecole Vincent d'Indy." the first institution in Quebec to accept the classical guitar as part of their curriculum, and of the left at the English McGill Conservatory.

It was the tension which developed between the two schools of technique and Fentok's refusal to fully accept either which led to an eclipsing of his prominence in Montreal for many years. The Lagoya style appeared to become a symbol of the French-Canadian guitarist: to be Quebecois was to play off the right. The rise of a cultural awareness in Quebec corresponded with the adoption of the Presti/Lagoya performance techniques. English Canada, although familiar with this technique, remained firmly rooted in the Segovia and, ultimately, the Julian Bream and John Williams schools of technique for many years. Fentok was unfortunately caught in the middle of the two schools, belonging to neither. 
TORONTO

Most of the first generation of post-war guitar teachers in Toronto were rooted more in folk rather than classical tradition. Ken Young. Norman Chapman, John Perrone, a flamenco guitarist, and Eugene Lucas, a Yugoslavian tho played and taught many different instruments, were among this group. All were basically selif-taught musicians with the exception of Chapman. Bertram Atkins and Eli Kassner were also part of this small but dedicated group of guitarists in Toronto during this period. The lives of Chapman. Atkins and Kassner will be outlined to give an indication of the diverse musical backgrounds, biographies and guitar activities of these first classical guitarists in Tcronto.

\section{Norman Chapman}

One of the earliest known solo guitar performances by a Zanadian guitarist was in 1948 by Norman Chapman. A paragraph that same year in the Guitar Review. a periodical published by the New York Guitar Society, made mention of the concert: 
November 1, 1948. His program included works by Sor, Handel, Mertz, Bach, Albeniz. Beethoven, Granados, Tarrega, and G. Gomez.?

This was certainly an impressive selection of pieces for a Canadian guitarist at that time. Eli Kassner recollects that Chapman was the only guitarist he knew during the early 1950 s who could play Tarrega's "Recuerdos de I'Alhambra."e

As a sailor. Chapman had traveled to Brazil where he had the opportunity to study with guitarist Isajas Savio (1900-1977). Upon his recirn to Toronto, he did some teaching and performing. One of his students was Frank Gay. who later became a fine guitar maker. Gay and Chapman formed a guitar duo until Gay's move to Edmonton in 1953.

\section{Bertram Atking}

Bertram Atkins was one of Toronto's best known guitarists during the 1950s. Born in 1885 in Toronto, he was educated at Upper Canada College before his life-long career in banking. After hearing a guitarist "strumming" at

TGuitar Review, No.7 (1948), p.1.

"Eli Kassner. "The Guitar Society of Toronto," from "Tribute to Eli Kassner," 27 May 1989, The Guitar Society of Toronto Archives (hereafter GSTA). P. 2 . 
a vaudeville show, he was convinced he could do better and started serious study.o

Atkins' first teacher was William Foder (1860-1947), an American guitarist who taught in New York City from 1912 until his retirement in 1939. He had a reputation "as the premier American-born guitarist" and wrote over 100 original works . 10

Luise Walker was Atkins' next teacher. He probably heard one of her two recitals in New York City in 1933, and subsequently went to Vienna to study with her. Walker was a student of Llobet and a well known concert guitarist in Europe, although her performances drew little interest in England and the United States.12

In Paris, Atkins continued his studies with Emilio Pujol, who had been a student of Tarrega from 1900-1907.

Lessons with Pujcl ended with the German advance into France in 1940. atkins rode a bike carrying his guitar to the Spanish burder... He was put in Petain's concentretion cals.p by French troops for eight months.

9John Bonfield, "Bertram Atkins." NAC, Music Division, n.d., p.1.

1ophilip J. Bone. The Guitar and Mandol in: Biographies of Celebrated Players (London: Schott. 1972), p.121.

12 Ibid. . p. 368. 
American friends got his release: he then taught guitar in Portugal.12

The 1950 edition of Guitar Review, included a photograph of Atkins representing Canada in a collection of photographs of guitarists from around the world. Atkins is best remembered for his library of guitar arrangements, which for that time were fairly extensive. These were left to the Guitar Society of Toronto after his death.

\section{Eli Kassner}

Born in Vienna. Austria in 1924. Eli Kassner's early musical training consisted of guitar and choral instruction from the age of eight.

At the age of $\mathrm{fifteen}$. Eli was fortunate to be accepted by Hadassah, a Jewish women's Zionist organization, as part of a group of sixty youths who were luckily able to emigrate to Israel.13

A Holocaust orphan. Kassner lived in different "kibbutzem" where he gained musical experience through posttions such as cultural director and choral conductor.

By 1951, Eli's brother was in Canada and urged Eli to come and join him. When he arrived, Eli says that for

2.2Bonfield, "Bertram Atkins," p.1.

13Harold Smith. "Eli Kassner: A Biography," from "Tribute to Eli Kassner," GSTR. 27 May 1989. p.2. 
the first time he experienced the feeling of being free. In Austria he had been oppressed by the Nazis; in Israel he was circumscribed by the besieged state of the country. He could now move and act according to his inclination. ${ }^{24}$

After his arrival in Toronto. Kassner obtained employment at the Whaley, Royce \& Co. music store on Yonge Street where he had the opportunity to meet other guitarists in the city. "The classical guitar was virtually unknown in Canada and was thought of as some kind of novelty instrument." 25 remembers Kassner in his personal history of the Toronto Guitar Society. The small group of guitarists played for each other, exchanging knowledge of the classical guitar.

We met several times and had some wonderful evenings performing our somewhat limited repertoire for each other. comparing $f$ ingerings and exchanging what little information we had about matters dealing with classical guitar literature. And when we ran out of solo repertoire we sang Mexican and Spanish songs, strumming lustily with lots of rasgueados and golpes.16

As Segovia's recordings became available in music stores. people wanted to be able to play like the maestro. Kassner

\footnotetext{
${ }^{14}$ Smith. "Tribute to Eli Kassner," p.2.

${ }^{18}$ Kassner, "The Guitar Society of Toronto." p.3.

26Ibid.. p. 3.

"Rasgueacio" and "golpe" are right hand techniques borrowed from the flimienco guitar style of playing.
} 
began to accept students, and strings. guitars and music were ordered into the Whaley \& Royce store.

The level of guitar playing across the country was very low for the most part in those years. Most performers were playing short student pieces such as "Romanze." "Adelita," and "Lagrima." A concert guitarist was one who could play "Austurias." by Albeniz, while Bach's music was attempted only by a master of the instrument. The level of performance rose gradually through the influences of recording technology and concerts. which inspired many guitarists to aim toward higher standards in their own playing.

Classical guitar instruction was not of fered at the Royal Conservatory of Music or the University of Toronto Music Faculty during the 1950s. It was seen as an instrument sujted only to the performance of folk, jazz or popular music. Kassner met with both Dr. Ettore Mazzoleni, Principal of the Conservatory, and Boyd Neal. Dean of the Music Faculty, in 1957 to discuss proposals for the guitar's acceptance.

Eventually, after much convincing, they invited me to play for them and to present an outline and a syllabus of such a guitar course. The audition and the presentation went very well and subsequently, in 1959 . they invited me to join their respective faculties and to start a comprehensive guitar program. This was the very first time that any university in Canada (and I believe in North America) had of icially recognized 
the guitar. The official recognition of the guitar. and the resulting prestige and legitimacy derived from it. gave us incentive to expand our activities.17

Before Kassner accepted the position of fered to him, he obtained a Canada Council grant to study with Segovia in 1958, after being invited by the maestro.

The first copy of the guitar syllabus for the Conservatory was drafted by Kassner. with examinations up to the grade ten level of performance. With the exception of a lower level of sight reading, the standard was not much different from that in today's syllabus. The bulk of concert programs during the 1950s, however, were still made up of short. single pieces. It was not until the next decade that iarger works such as entire sonatas and suites were played in concerts.

17Kassner. "The Guitar Society of Toronto." p.3. 
HALIFAX

There was little classical guitar activity in Canada outside of Montreal and Toronto during the 1950s. One figure to emerge in Halifax during this time was Caról Van Feggelen. Born in Holland, he had extensive musical training in clarinet and voice at autch Conservatory before coming to Canada in 1955 with the Canadian army. At that time, the Canadian army wanted to develop a strong musical programme like that found in the Dutch army, so recruited many Dutch musicians.10

Van Feggelen was stationed in Hal ifax where he was very active for many years as a performer. He was employed by the CBC, and played music for the Max Forguson Show. The classical guitar was not known in Nova Scotia at that time. and since music was not available. Van Feggelen had to make special orders for Segovia's recordings and learn the music by listening to them.

In 1958, Van Feggelen established the New Brunswick Chamber Music Group with a group of Dutch performers. They played a number of concerts in the Maritime region, Van

10 Personal interviow with Caról Van Feggelen, Halifax. September 1989. 
Frggelen performing on the guitar. In the early years of the next decade, he left the army and his performing career to become a full-time teacher of the guitar, teaching at the Maritime Conservatory. After playing a Giuliani Concerto at the Hal ifax Conservatory which Ettore Mazzoleni heard. Van Feggelen was encouraged to move to Toronto. It was there that he became a part of the growing number of guitarists in the city, and contributed much to the growth of the classical guitar during the next three decades.

III

THE FORMATION OF THE TORONTO GUITAR SOCIETY

In 1953. Eli Kasener, John Perrone, Eugene Lucas, Norman Chapman, Ken Young and Bortram Atkins attempted to form a guitar society in Toronto, but failed due to personality conflicts between the men. Two other attempts were made in the following two years, but met with the same fate. In December of 1956, a third and ultimately successful attempt was made to form a society. Thirty people joined and a committee was elected, making it the second society in North America, the first being the New York Guitar Society, established in 1946. 
The motto of the society was "to foster understanding. appreciation and the study of the guitar."19 Meetings were held monthly, each featuring guest guitarist. In January 1957, folk singer Igors Gavon played, followed by another folk guitarist, Raphael Nunez, in February. 20 The March meeting featured jazz guitarist Ed Bickert, and folk guitarist Greg Curtis played at the April meeting. The first season closed with Hans Kohlund, a Baroque lutenist originally from Frankfurt. He played both the guitar and lute, discussing their differences in technique and repertoire.a1 The National Film Board documentary "Corral" was also shown at this meeting, featuring the soundtrack for two guitars by Canadian composer Eldon Rathburn. 22

In March of the same year. Segovia wrote a letter to the society accepting the position offered to him of honorary president. A party was held in his honour after his concert at Massey Hall on April 8th. An article in the society's bulletin later described this event:

I know that most people haped that Segovia would do us

19Guitar Society of Toronto l. -tin, Isgue 1, 1957-1958, GSTA, p.1.

${ }^{20}$ Ibid.. p.1.

a1Guitar Society of Toronto Bulletin. 1957-1958, p.2. 2 Ibid. . p. 2. 
the honour of playing for us. Although he declined to do so, he did us an even greater favour. He asked to hear our members perform, and then spent an unforgetable hour criticising with marvellous patience and strictness. There is nothing that could have inspired us on to ideals of higher musical standards. Through his comments and criticism we were able to see the meticulous attention to details that goes into making a superb artist like Segovia. ${ }^{23}$

The first year of the society did much to encourage and educate students of the instrument. By the end of the season, the membership had doubled in number to sixty-three, showing the growing interest in the guitar. The society tried to achieve a iigh standard of musical performance during each of its meetings and attempted to "enlist the support of leading musicians in the city."24 Consequently, a letter was sent to composer Harry Somers on April 2, 1957 inviting him to join the society, which he accepted.

Societies have played an importart role in the history of the guitar, especially in Europe. Because classical guitar leans toward solo playing. many members do not have the opportunity to hear others play and discuss problems in technique and performance. This void is quite successfully filled by societies similar to the Guitar Society of Toronto.

\footnotetext{
${ }^{23}$ Guitar Society of Toronto Bulletin. 1957-1958, p.2. 24Guitar Society of Toronto Bulletin. 1958, p.1.
} 
By the end of the first season of the society. however, conflicts were developing between the folk and classical guitarists. A letter written by Kassner appeared in the March bulletin proposing the society be restricted to the classical guitar.

The guitar, being an extremely versatile instrument, can be used for a great number of musical purposes.... However. the ferformance of classical works requires a minimum technical proficiency without which most of their beauty is lost.... A great number of our members would enjoy listening to well-performed classical guitar but, in Toronto, guitarists who could meet this requirement are few. ... The majority of the members of the society are... "early stage" students who find themselves more at ease in the less complicated medium of folklore and simple accompaniments... As time goes on ... we will be in a position to work towards more comprehensive programmes.25

This division between the two styles of guitar playing resulted in the cessation of the emphasis on folk guitar. The society became dedicated to the understanding. appreciation and study of the classical guitar.

The second season of the Toronto Guitar Society proved to be even more ambitious than the first. A concert by Rey de la Torre, a Cuban guitarist who had studied with Llobet. was sponsored by the society on 8 January 1958. Ten people guaranteed one hundred dollars each in the event that the concert lost money. Eaton Auditorium was rented and the

25Guitar Society of Toronto Bulletin. 1957-1958, p.2. 
profit from the concert exceeded five hundred dollars. This moniy formed the start of the society's scholarship fund. An article in the bulletin described the success of this venture:

\begin{abstract}
We feel that the guitar society has influenced the musical life of Toronto this year. This was by sponsoring a recital at Eaton Auditorium by Rey de la Torre in January. For seven years there had been no public solo guitar recitals, though Andres Segovia had appeared with the Toronto Symphony Orchestra. The public was not getting opportunities to hear classical guitar and they responded encourag-ngly when we acted and sponsored the recital. The success was published in England. Ultimate proof is seen in the announcements of the concerts for this season. There will be three guitar concerts: Julian Bream on November 6th. Carlos Montoya, November 17th, and Segovia on April 28th. 26
\end{abstract}

The concert was a success largely due to Kassner's efforts and perseverance in obtaining the booking and financial backing. The ability of a small society to sponsor an international artist was met with a great deal of skepticism. 27

Fifty dollars from the society's scholarship fund went toward a commission for a guitar work by Harry Somers. He accepted, and his "Sonata for Guitar" became the first published solo work written by a Canadian composer. The

${ }^{26}$ Guitar Society of Toronto Bulletin, March 1958, GSTA, p. 2. 27Personal interview with Eli Kassner. Toronto. February 1988. 
piece was published in 1963 and premiered the following year by Peter Ackner. In his article. "Canadian Music for Guitar." Michael Strutt comments on the style of this Sonata, a work which he has also recorded:

Although not a performer on the instrument, Somers does play the guitar and. as parallel movement was a favourite device in his earlier piano music, it is not surprising to find it in this piece used in a most intelligent and succinct manner. The influence of Weinzweig (who developed exercises to exploit a single line) is seen in Somers who favours extended melodic lines, often with a strong rhythmic drive. Second of the Sonata's four movements, the scherzo grows out of and returns to a single, repeated note in a strong triple metre.2o

Other activities during the $1957-58$ season included a member's concert in which Kassner, Lucas and Perrone performed, and a student contest. There were three categories - beginner, intermediate and flamenco. It is interesting to note the inclusion of a flamenco class after the society's efforts to limit the society to classical guitar.

There was much correspondence during these early years with guitar students, teachers and other newly-formed societies across the continent. The Washington and Buffalo Societies were established in 1958 and exchanged builetins 
with Toronto.20 Robert Nevou, a teacher in Vancouver, wanted advice on starting a society. This would have been the first guitar society in western Canada. followed by the Edmonton Guitar Society, started in 1959 by Frank Gay, 30 a guitar maker and former student of Norman Chapman. In 1959. the Vancouver Society invited the Seattle Society to play for them. but unfortunately Nevou wrote again to say the Vancouver soriety had fallen apart.31 More details about the guitar background of Robert Nevou are not known.

The Buffalo Society followed Toronto's example and sponsored a concert by Rey de la Torre in 1959. Soon after. five members of the Toronto Guitar Society (Kassner. Perrone, Lucas. Young and Adams) played a concert for members of the Buffalo Society. This exchange continued for many years.

The Guitar Society of Toronto made some very important contributions during its first four years of existance to the development of the classical guitar in Toronto. Asking Andrés Segovia to become the honorary president of the society and his resulting acceptance brought the prestige of

29Washington and Buffalo Guitar Society Bulletins. 19581960. GSTA.

30"Gay, Frank," Encyclopedia of Music in Canada (Toronto: University of Toronto Press, 1981), p.369.

${ }^{31}$ Letters from Robert Nevou, 1958-1959, GSTA. 
the society to a high level. This is seen in the remarkable transition from local folk guitarists conducting monthly meetings during the first season to the sponsoring of an international classical guitarist during the second season.

IV

CONCLUSION

The decade of the 1950 s were years of much experimentation and growth of the classical guitar across Canada. A small number of guitarists learned what they could about classical guitar from each other, teachers in other countries, listening to Segovia's rerordings, and from attending the relatively few guitar conrorts in the major centres.

Table IV:1 summarjzes the majority of the classical guitarists in Canada from 1945 to 1960. Their countries of birth are noted, as well as the classical guitar teachers they had and where these lessons were obtained. The results indicate a similarity between the guitar in early Canada (1630-1920) and the early classical guitar in Canada (19451960). 
TAELE IV: 1

CLASSICAL GUITARISTS IN CANADA FROM 1945 TO 1960

GUITARIST COUNTRY OF BIRTH GUITAR TEACHERS

Stephen Fentok Montreal. Canada Alexander Bellow, USA

Emilio Pujol. Italy

Alirio Diaz. Italy

Presti/Lagoya. France

Norman Chapman Toronto, Canada Isaias Savio, Brazil

Bertram Atkins Toronto, Canada William Foder. USA

Luise Waliker. Austria

Emilio Pujol. Italy

Eli Kassner

Vienna, Austria

Mainly self -raught Andrés Segovia. Spain

Caról

Holl and

Mainly self-taught

Van Feggelen

Andrés Segovia. Spain

Eugene Lucas

Yugoslavia

Mainly self-taught 
Without exception, all of the early classical

guitarists in Canada were either self-taught or trained in the United States or Europe. There were not the quality teachers available in Canada during that time that could be found outside the country. Instruments and music also came from other countries. This situation was similar to that of the guitar in early Canada, as seen in chapters two and three. Guitar teachers generally received their musical training in Europe, and instruments and music had to be imported to Canada.

Another similarity between the two eras of guitar in Canada were the influences from other countries. Early guitar in Canada went through a period of European influence, followed by the American influence during the late nineteenth century. The classical guitar in Canada during the 1950 s was influenced by guitarists from many different countries. There was a South American influence through Chapman's lessons with Savio, and the French influence through Fentok's studies with the Presti/Lagoya duo. Concerts by international performers such as Julian Bream. Rey de la Torre and the Presti/Lagoya duo also had an influence on Canadian guitarists.

The strongest influence, however, was that of Andrés Segovia. His concerts in Montreal and Toronto, and his recordings, available in most larger centres, had a 
tremendous impact on the guitarists in Canada. Many became interested in the instrument after listening to his recordings. Segovia set a standard of performance on the classical guitar which many Canadian guitarists strove to obtain.

This chapter has outlined classical guitar activity in Canada after World War II through the decade of the $1950 \mathrm{~s}$. The reasons for the development of interest in the instrument have been explored, as well as the major teachers and performers of the classical guitar in Canada during that period.

These were certainly formative years. The classical guitar was gaining acceptance as a legitimate concert instrument durir $\vec{g}^{\text {this }}$ period, with the number of concerts by international performers increasing each year. Starting with Stephen Fentok and his establishment of a classical guitar curriculum at Montreal's McGill Conservatory and "L'Ecole Vincent d'Indy." the instrument gained prominence in Toronto as well when Eli Kassner started programmes at the Royal Conservatory of Toronto and the University of Toronto Music Faculty.

The decade of the 1950 s also saw the beginning of a division between the folk guitar and the classjcal guitar. both in Toronto and Montreal. As the classical guitar 
became accepted into concert halls, conservatories and music faculties, it seemed to develop into an instrument of the elite. The legitimacy of which Kassner wrote resulted in the formation of a hierarchy between the different styles of guitar. the classical technique being superior to the others. This will be explored further in chapter five. with a discussion of the classjcal guitar during the 1960 s. 


\section{CHAPTER FIVE}

THE DECADE OF THE 19605

I

INTRODUCTION

During the decade cif the 1960s, the classical guitar in Canada was rapidly expanding and reaching higher standards of performance and teaching. This chapter will document significant events which took place during this decade and contributed to the eventual attainment of world.class excellence in the field of classical guitar.

Toronto and Montreal continued to be' ajor centres for the classical guitar in Canada during the 1960s. Other rities such as Québec City and Vancouver, however, also started to build active classical guitar circles during this time with the availability of more teachers of the instrument. As this chapter will show, both teachers and students were still very much influenced by European guitarists, many attending master classes or private lessons with performers of international calibre. Advanced training 
at the post graduate level on the classical guitar was still not avajlable in Canada.

Both the Guitar Society of Toronto and government grants available through the Canada Arts Council made significant contributions to the training of classical guitarists in Canada during the 1960s. Funds by both organizations were made available to students to attend master classes, either in Canada or Europe. The number of international guitarists performing and conducting classes in Canada increased tremendously in this decade, making it easier for Canadian students to attend concerts and classes.

Another significant milestone during the 1960 s was the establishment of a guitar making industry in Canada. The demand for these costly, hand-made instruments was a reflection of the increasing standard and number of classical guitariats across the country. As this chapter will point out, some of these Canadian-made guitars were purchased and played by world class guitarists, bringing international recognition to these guitar makers.

This chapter will also explore the role of the Guitar Society of Toronto in helping to promote the achievements of Canadian classical guitarists in many other countries. Since Toronto remained as the centre of classical guitar in 
English Canada, it will be discussed first, followed by a comparison with the guitar in French Canada.

II

TORONTO

The classical guitar in Toronto during the 1960s continued to expand. The Guitar Society of Toronto attracted more members each year and sponsored many concerts each season by both international performers and young promising students within the society.

On June 28, 1960, Eli Kassner wrote a letter to William Sloan, Chairman of the Toronto Kiwanis Music Festival, regarding the inclusion of a guitar class in future festivals. A return letter read:

The work of Mr. Eli Kassner in suggesting classes and test pieces for the classic guitar is duly noted and a warm vote of thanks is extended to him.1

\footnotetext{
${ }^{1}$ Letter from William sloan. August. 1960. GSTA.
} 
The 1961 Kiwanis Festival saw the first guitar classes, with guitarist and lutenist Hans Kohlund as the ajudicator.z The test pieces were as follows:

$$
\begin{aligned}
& \frac{12 \text { and Under }}{\text { "Study No. 6" - Giuliani }} \\
& \frac{16 \text { and Under }}{\text { "Little Prelude" - Bach }} \\
& \frac{19 \text { and Under }}{\text { "Prelude } \# 1 " ~-~ V i l l a-L o b o s ~} \\
& \frac{\text { Open and Open Duets }}{\text { Own choice - } 5 \text { minutes maximum }}
\end{aligned}
$$

The inclusion of a duet class was likely influenced by the Presti/Lagoya duo. Copies of the syllabus were sent to the teachers, and the numbers requested by each teacher give an indication of the student body at that time: Eugene Lucas (5), Eli Kassner (20), John Perrone (2), and the guitar society (10).4 Copies were also sent to the Buffa1o and New York Guitar Societies, maintaining the close communication between the growing number of societies in North America.

Correspordence continued with the Toronto Guitar Society with guitarists from all over the continent during

\footnotetext{
aGuitar Society of Toronto Bulletin. March, 1961, GSTA, p.2.

3Guitar Society of Toronto Bulletin. March, 1961, GSTA, p.2. 4 Ibid.. p. 2 .
} 
the early years of the 19608 . Information was requested regarding the purchase of strings and guitars, names of teachers in various locations of the country. and guidelines to setting up new guitar societies. A letter of 1960 was from one of the only classical guitarists in the state of Florida. In 1962, the Kentucky Society wanted assistance in setting up a successful guitar society. A guitarist in Poland wanted a set of nylon strings sent to him, as they were not available in his own country.5

It is interesting to note that letters from American guitarists were sent to the Guitar Society of Toronto rather than the New York Guitar Society, and that the Polish guitarist did not write a society in Europe or the large mociety in London. The Toronto Guitar Society was well established by this time, and perhaps had a larger reputation in North America than other societies on the continent. It is also possible that society members had connections with guitarists from the United States and Europe. Whatever the reason, through this network of communication, the Toronto Guitar Society helped to unite and educate guitarists in marginalized areas of the continent. 
A letter in 1964 to the society in Toronto from the Chicago Guitar Society confirms the theory of Toronto's large reputation in the United States.

I want you to know we are really impressed with the activities of your society. The presentation of ten guitarists in eight years is a real feat and doubly so, since you have not neglected your own players in the process. Your society is really doing a service for the guitar.6

The society also wanted a copy of Harry Somers" "Sonata for Guitar." which had been premiered that year.

In April of 1965. the first international guitar festival was held in Japan in honour of Andrés Segovia and Emilio Pujol. Gujtarist Yajumasa Obara. director of the festival, wrote Kassner:

After the festival I wish to call on your place and have a small recital, where we will be able to talk together on guitar and promote mutual understanding. It would be my greatest pleasure if we could contribute more or less to guitar music by such relationship.?

The second annual festival was held the following year, and the Guitar Society of Toronto was asked to be the honorary adviser of the Japanese Federation. The Guitar Society of

6Letter from Chicago Guitar Society. April 17, 1964, GSTA.

'Letter from Yajumasa Obara, April 1965. GSTA.

'Letter from Yajumasa Obara. February 1965. GSTA. 
Toronto had certainly gained an international reputation by this time.

During the decade of the 1960 s there was much interest in the classical guitar in Toronto and many other regions in Canada. An article in the 1965 bulletin of the Toronto Guitar Society attempted to explain this trend:

The rise in interest in the clasic guitar is shown in the rise of our membership. This is part of a general "cultural explosion" in North America. perhaps caused by more leisure, more education and more money. 9

Certainly these factors played an important part in the rise in popularity of music, but do not account for the rise in interest of the classical gujtar specifically. The increase in exposure to the instrument would have been a major element in its growth. International artists visited the country with regularity, creating interest and setting higher standards of technical ability.

The popularity of "rock and roll" music and the growing interest in both the electric and acoustic guitars in the 1960 s also contributed to the rise of interest in the classical guitar. The development of American popular music and its eventual domination of North American airwaves

"Guitar Society of Toronto "Bulletin". October 1965, GSTA, p.1. 
created a resurgence of public appeal for the guitar across the continent. The classical guitar provided an alternative to rock, folk and jazz styles of guitar performance, as well as a solid technical foundation for many aspiring young rock guitarists.

Not only was the interest in the classical guitar increasing, but standards of performance were becoming much higher. Two factors can account for this. First, as mentioned earlier, international performers were giving recitals in Toronto with regularity and their recordings were readily available in some music stores. During stays in the city, many performers also gave master classes and private lessons, often inviting more promising students to go and study with them. Both Kassner and Van Feggelen, for example. played for Segovia and received the honour of being invited to further their studies with the maestro. Van Feggelen, who studied with Segovia numerous times, even received a personal scholarship from Segovia to study with him in Spain. Lessons with international performers acquainted Canadian guitarists with new repertoire and performance techniques which they could in turn use to improve standards in Canada.

A second factor in the rise of performance in Toronto was the rivalry between guitar teachers in the city, 
specifically Kassner and Van Feggelen.10 For the ten years Van Feggelen lived in Toronto (1964-1974), he taught at the

Royal Conservatory of Music in Toronto. Cambrian College in Sudbury, and Queen's University in Kingston. Kassner had opened his own guitar academy in 1967, and also taurht at the University of Toronto. Bisth men were dedicated to the teaching profession. having put their performance careers behind them. Consequently, each was committed to producing the most outstanding students.

Both Kassner and Van Feggelen were (and are) successful teachers, and educated many young guitarists during the 1960s. In his personal history of the Toronto Guitar Society. Kassner wrote:

Our own standards and expectations also becan to rise. A new generation of young guitarists grew up in an atmosphere of recognition and appreciation. Our monthly meetings featured teenagers Liona Boyd. Martin Polaschek. Amparin Prieto. Lynne Gangbar. Danny Beckermann. Eddie Moench, and many others who have gone on to become performers and teachers all over the world. In 1965. Julian Bream held a masterclass in Stratford, Ontario and he expressed his amazement at the high level of accomplishment of our students.11

\footnotetext{
10 Personal interviews with Eli Kassner. Toronto. February 1988, and Caról Van Feggelen, Hal ifax. September 1989.

11Eli Kassner. "The Guitar Society of Toronto: A Personal History." in "Tribute to Eli Kassner." 2'7 May 1989, GSTA. p. 2 .
} 
Julian Bream and Alexander Lagoya continued to give master classes in Stratford from 1967 to 1973 as part of the Stratford's Annual Performing-Arts Festival. The Toronto Guitar Society of Toronto offered financial support to enable young guitarists to attend these classes.

Participants included Liona Boyd and Lynne Gangbar of Toronto, Michael Laucke of Quebec. Robert Jordan of Vancouver, and Ray Sealey of London. Master classes during the 1960 s were also given by guitarists such as Oscar Ghiglia (1967 and 1968) and Alice Artz (1970).

As seen, the Guitar Society of Toronto played an important role in the continued development of the classical guitar in Toronto, and influenced societies in other parts of the world as well. Through their studies with international guitarists. teachers in Toronto were able to increase their knowledge and produce many promising young students during the $1960 \mathrm{~s}$, who went on to contribute to the guitar in Canada during the next two decades. 


\section{III}

QUEBEC

The classical guitar also continued its rise in popularity in both Montreal and Québec City during the 1960s. Due to guitarists from other countries immigrating to Québec and the tremendous influence of Ida Presti and Alexander Lagoya, a number of new classical guitarists emerged during this time, such as Marie Levesque. Martin Prevel and Paul Gerrits, all of whom continue to be very influential educators to this day. Younger guitarists who were to gain prominence in the next decade, such as Peter McCutcheon and Paul-André Gagnon, were products of the higher standards of performance developed through the decade in Québec music faculties and conservatories.

Marie Levesque started guitar lessons with Stephen Fentok. then continued as a student of both Ida Presti and Alexander Lagoya from 1964 to 1968. Since classical guitar instruction was not of fered at "Le Conservatoire de Paris" until the end of the 1960s, Levesque studied with the couple privately in their home. After gaining the "Premier Prix de la Schola Cantorum", she returned to Canada and started the first guitar class at the "Conservatoire de Québec à 
Montréal" in 1968. After Levesque's move to Québec City, Fentok took over her classes at the Conservatory.

Paul Gerrits, who started the guitar programe at Laval University in 1907, is one of only three full time professors of the guitar in Canadian universities.12 Gerrits was born in the Netherlands and began his musical studies on the lute with Walter Gerwig in Germany. His giltar teachers included Karl Scheit in Vienna and P.O. Johnson in Sweden.

Stephen Fentok continued to teach guitar in Montreal. but was rot performing as much in the 1960s. In 1962, he received a Canada Arts Council scholarship to attend the summer school of the International Academy of Music in Nice, France, where Presti and Lagoya taught. He returned to Europe to study with Alirio Diaz, but, as discussed in chapter four. encountered problems with the debate between right- and left-hand techniques. Fentok continued to maintain that the right-hand technique of the Presti/Lagoya duo was an imperfect method of playing the guitar. In Québec at that time, however, most guitar teachars such as Marie Levesque favoured the technique of the irenzh duo over that of Segovia's.

${ }^{12}$ The other two full time professors of guitar in Canadian universities are Michel Cardin. University of Moncton, and Carbl Van Feggelen. Dalhousie University. 
In 1967, Fentok was commissioned to write and record the music for the Olympic Pavillion at Expo '67. He was asked to compose a piece for the classical guitar that showed the progression of the human race from Roman times to the twentieth century. The motif from Beethoven's Fifth Symphony was also to be included as it was considered to be a universal theme. The classical guitar was chosen because the guitar was an instrument to which the youth could relate, and the classical guitar was considerd to be a "youthful instrument," a relative newcomer on the concert stage in Carada. Fentok managed to accomplish this challenge with great success.

Fentok's composition was a rare event during the 1960 s. Little Canadian music for the classical guitar was published or performed in Quebec or other parts of the country. al though the instrument was gaining much recognition in concert halls and music faculties. In his article, "A Short History of Classical Guitar in Canada," Alan Torok puts forth a very valid argument for this occurrence:

My own explanation is that the Canadian guitar talent pool was very shallow in the $60 \mathrm{~s}$. There simply were no performers to play the professional quality compositions then available. Kassner had retired from performance in 1967. while the students who were to make him 80 well known in the future had yet to develop. Carl Van Feggelen, then another influential teacher, was in the same position. Stephen Fentok and Antonin Bartos, guitarists active in Montreal, were known as teachers and appeared to have made no impact 
as performers. The French duo of Alexander Lagoya and Ida Presti taught summer courses in Québec throughout the mid-'60s but they, too, did not produce first-rate students until the early' 70 s.2s

In the next decade, however, there were numerous Canadian performers, many of whom played works by Canadian composers. These younger guitarists will be discussed in chapter six. 
IV

VANCOUVER

The major classical guitarist in Varicouver during the 1960 s was Oxford-born Robert Christopher Jordan (b.1933). His first career was as an orchestral violinist. In 1952. he arrived in Canada and taught himself to play the guitar two years later. Jordan furthered his studies in 1964 and 1966-67 in Spain with Eduardo Sainz de la Maza. as well as at the University of British Columbia from 1965-67.14 Jordan was also one of the participants at the 1967 Stratford master class with Julian Bream.

In 1969, Jordan started the Classical Guitar Centre in Vancouver and became known in the city as a teacher. performer, composer and arranger.25 He was responsible for the development of a very active classical guitar society in Vancouver at that time, featuring monthly meetings and weekly guitar parties.

14"Jordan, Robert Christopher." Encyclopedia of Music in Canada, p.485.

${ }^{28}$ Ibid.. p. 486 . 
V

\title{
GUITAR MAKERS
}

\begin{abstract}
Although there was a market for custom-made steel string guitars in Canada during the late 1950s, the demand for good classical guitars did not come until the next decade. Until then, those wanting a hand-made guitar would have to go to Spain for a Ramirez or another prominent maker in Europe. With the rise in the standard of performance and the number of classical guitarists in Canada came a demand for better quality instruments. The foundation for a thriving guitar-making industry was established during the 1960 s as a result of this need.
\end{abstract}

This section will disclas the backgrounds and influences of three of Canada's first classical guitar makers. Patt Lister and Frank Gay started building classical guitars during the 1960s, although both made steel string guitars well before that time. Edgar Moench came to Canada in 1965 tu build guitars, and during his stay had a tremendous influence on the guitar making industry in Canada. 


\section{Patt Lister}

Born in England in 1916. Patt Lister moved to India at an early age with his family. It was there that he developed his 1 ifelong interest in stringed instruments.

I was absorbed by the mystic music of the East. I heard and fell in love with the sitar. It arroused my first interest in stringed instruments. I was enthralled by the itinerant bands of musicians featu.ing flute and exotic stringed instruments.16

After hearing Andrés Segovia play a concert at Wigmore Hall in 1934. Lister purchased his first classical guitar.

From this he eventually graduated to a $\$ 500$ Ramirez. But he grew dissatisfied with it after a time and, being a technical experimenter, decided to make a guitar of his own. It was produced in his bedroom with rudimentary tools - most of them borrowed.17

Lister had wanderlust and traveled to Canada in the early 1930s.1e He returned in 1956 to live, and cortinued to build guitars, also taking the opportunity to s"udy classical guitar with Eli Kassner. Lister's first classical guitar was made in 1964, and since that time his guitars have gained much praise. Internaticnal concert guitarists

${ }^{16}$ Hugh Thomson. "Guitar Maker Patt Lister keeps on trying for perfection." Globe ard Mail. 2 August 1974. p.10.

17 Ibid. . p. 10.

2 Ibid. . p. 10 . 
Alice Artz and Julian Bream both own and have recorded albums with Lister's guitars.10 An article in the 1966 Toronto Guitar Society Bulletin reads:

When Julian Bream arrived in Toronto he discovered that the strings of his concert guitar had gone completely dead. A new Patt Lister guitar was produced for him. and he played the entire recital on a green guitar that had never been played before. Julian Bream was quite enthusiastic about the guitar, especially its qualities of projection, and took the guitar on tour with him. I'm sure all that heard the concert will agree it was a perfect combo. 20

Completely self-taught, Lister experimented with many different types of wood, most of them from Canadian forests.

I have several people buying the choicest West Coast cedar for me and it is yielding splendid results.... I also use the finest Canadian maple for the backs and Canadian pine for the necks. Only the ebony for the fingerboards is imported.21

His guitars are instruments crafted with Canadian wood and designed to be able to withstand the country's varied climate. Free from influences of an actual mentor, Lister was able to develop his own unique and ultimately very successful style.

19Thomson. "Guitar Maker Patt Lister." p.10. 20Guitar Society of Toronto Bulletin. November 1966. GSTA, p. 3 . 


\section{Frank Gay}

Born in 1920 north of Saskatoon. Frank Gay did his early musical study at the New York School of Music in the late 1930s. followed by classical guitar lessons with Norman Chapman in Toronto.z2 After apprenticing for two years at the R.S. Williams Company in Toronto, Gay moved to the West because he "heard Edmonton was a real boom town. And the climate here is one of the best for guitar making."as Gay had three guitars he used as his models: a Ramirez flamenco, a gift from Carlos Montoya, a 1929 Esteso classical, and a Spanish guitar once owned by Rey de la Torre. 24

Gay's first guitars were steel string instruments which are owned by musicians such as Johnny Cash. Webb Pierce, Don Gibson and Hank Snow. Three of his instruments are in the Nashville Hall of Fame. 25 In the 1960s, Gay started to construct classical guitars, eventually making instruments for Alirio Diaz and Carlos Montoya.

Much of the wood for Gay's guitars is imported from a company in Germany, although he uses Canadian cedar for the

22"Gay, Frank," Encyclopedia of Music in Canada. p.369.

${ }^{23}$ The Star Phoenix (Saskatoon), "Guitars Gain Fame for Quality Work." 27 June 1973. p.47.

${ }^{24}$ Ibjd. . P. 47.

${ }^{25}$ Ibid. , p.47. 
tops.26 It is for the fine quality of his guitars' inlay work that Frank Gay is best known.a7

\section{Edgar Moench}

Edgar Moench was born in Leipzig where his father was conductor of a cafe orchestra. He learned the violin from his father, but after his parents divorced before World war I. he moved to Russia with his mother. Later, he studied machinery in Prague before being drafted into the army at the start of World War II.

Fourteen days before D-Day he was taken prisoner in Normandy and shipped to England, where he worked for a year on a farm, then was sent to a prisoner-of-war camp to work in the camp's instrument shop under the direction of Mathias Mehni, a violin maker of some reputation from Breslau. Mehni made violins and Moench. guitars.2e

26 "Guitars gain fame for quality work," p.47.

27"Gay, Frank,". Encyclopedia of Music in Canada, p.370.

2eHugh Thomson. "Edgar Moench: The Stradivarius of Guitarmakers," Globe and Mail (25 June 1966), p.14. 
Moench was largely a self-taught maker. although he spent three to four weeks with luthier Barbello learning to make rosettes 29

Moench set up his first guitar studio in stuttgart after the war, then moved to Munich in 1950. He soon gained a reputation as a master craftsman, and made guitars for performers such as Andrés Segovia. Julian Bream, John Williams and Vincente Gomez. ${ }^{30}$ After meeting Eric Mundinger while buying strings in Toronto. Moench signea a contract to move to Canada and build guitars in Toronto.

During his six years in Canada (1965-1971). Moench had a tremendous influence on guitar making in the country. Moench's nephew. Kolya Panhuysen, learned the secrets of the art from his uncle. and still uses Moench's old studio in Germany to build for his European market. Jean-Claude Larrivée apprenticed with Moench for over five years. In turn. Larrivée has become one of Canada's best known builders, now established in Vancouver. Among his apprentices were Sergei de Jonge, William (Grit) Laskin. George Gray, David Wren. Linda Manzer and Michael Schreiner, all of whom have had their own successful careers in guitar making .

29Personal interview with Kolya Panhuysen. Toronto. December 1989.

3oThomson. "Edgar Moench." p.14. 
Moench returned to Germany in 1971 where he died in 1977, but his influences are still felt today in Canada. His superb craftsmanship brought the standard of guitar construction in Toronto to a high level. Through Larrivée, this art has been passed on to many Canadian guitar makers, who have built on Moench's techniques to create their own unique guitars.

\section{VI}

CONCLUSION

This chapter has documented the continued growth and expansion of the classical guitar during the 1960 . Although standards of teaching and performance were increasing during this time, the classical guitar continued to be influenced by European guitarists. The guitar in Canada was still in a period of growth, and had not yet reached world class standards in performance or education. Canadian composers were nut writing large numbers of works for the instrument at this time. 
Perhaps the most important event of the $1960 \mathrm{~s}$ was the development of a guitar making industry in Canada. The influences of German luthier Edgar Moench were to be felt during the next two decades of guitar making in Canada, both in the continuation of his fine craftsmanship and in the development of interest in the art through his long-time apprentice. Jean-Claude Larrivée. Frank Gay and Patt Lister were the first Canadian guitar makers to gain international acclaim for their instruments.

It is during the rext two decades, however, that Canadian guitarists, composers and makers really make an impact on ihe world of the classical guitar, as will be seen in chapter six. The decade of the 1960 s marks the end of what was essentially a long period a derelopment of the instrument in Canada. 
CHAPTER SIX

THE ATTAINMENT OF INTERNATIONAL RECOGNITION:

$1970-1990$

I

INTRODUCTION

The last two decades of classical guitar activity in Canada have been years of enormous growth and achievement. Interest in and recognition of the instrument have reached their peak during this period. This is evident in the large number of Canadian composers writing for the instrument, the acceptance of the classical guitar into almost every music faculty and conservatory across the country, the thriving community of guitar makers in many provinces, the recognition in many parts of the world of some of Canada's performers, and the encouraging support for concerts, competitions and international festivals.

The twenty-five year period after World War II was a time of development and growth of the guitar in this country, as explored in chapters four and five. Since 1970 , the early ambitions of the small number of pioneers in the 
field of classical guitar have been realized. It would be difficult to make a division between the last two decades as one was a continuation of the other's successes.

This chapter will examine some of the people and events which contributed to this success and helped to raise the level of classical guitar in Canada to that of a. world class centre for the instrument. Achievements by some prominent performers and teachers across the country will be documented, as well as Canadian compositions for the classical guitar. The important role of Toronto's international guitar festivals in uniting classical guitarists from many different countries and encouraging composers to write for the instrument will also be discussed.

An analysis will be made of the relationship between the availability of government funding for classical guitar performers, composers and societies and the increased standards of the classical guitar in Canada. This chapter will attempt to show the importance of Canada Arts Council grants and other government funding to the classical guitar in Canada. 
II

PERFORMERS AND TEACHERS

The majority of performers in Canada today are also teachers, as the financial rewards of playing classical guitar concerts are not usually high. Sonse of the country's most renowned teachers are, however, no longer performers, having dedicated their talents to a full-time teaching career. This analysis will examine some of the teachers and performers of the classical guitar in Canada today.

Much of the information has been acquired from the questionnaires sent across the country. These list the individual contributions made by guitarists in the majority of provinces in areas such as performance, education. composition and adjudication. Further information was obtained from biographies in The Encyclopedia of Music in Canada and various articles in newspapers and magazines on specific Canadian guitarists. Canada's best known performer is Liona Boyd, who will be discussed separately as she has acquired a status quite different from that of other classical guitarists in Canada. 


\title{
Liona Boyd
}

\author{
Much controversy surrounds Liona Boyd's image as a \\ classical guitarist. Tom and Mary Anne Evans have argued:
}

Liona Boyd, a British-born Canadian player, has garnered a good deal of attention that is due more to her long blond tresses and her soft-focus album covers than to her playing. which may be generously described as sub-standard in these times of technical excellence and impressive ingenuity. ${ }^{2}$

This criticism is one of the only references to a Canadian guitarist in any book on the classical guitar. The classical guitar in Canada is still associated with Liona Boyd, although she has left that style of playing for the more profitable commercial music market. Evans' comments are shared by a great majority of classical guitarists, many within Canada, who object to their association with Boyd. Everything from her 1 imited choice of repertoire to her use of a microphone to amplify the guitar during concerts has been criticized.

Boyd's achievements since her graduation from the University of Toronto in 1972 are extraordinary. A fourtime Juno Award winner as "Instrumentalist of the Year," she has made $f$ ifteen record albums and received both the Vanier

\footnotetext{
1Tom and Mary Anne Evans, Guitars: From the Renajssance to

Rock (New York: Facts on File, 1977), p.45.
} 
Award and the Order of Canada for her cultural contributions. She has performed for heads of state around the world and appeared on numerous "talk shows." Both Guitar Player Magazine and Frets Magazine have published results of their international polls which ranked Boyd as the number two classical guitarist in the world.

Primarily an entertainer, Boyd has broken barriers between classical music and popular music, assisted by her very marketable image and her performances of the lightest pieces from the classical guitar repertoire. In her article, "Boyd: Bridging the Pop-Classical Gap." Audrey Ashley commented on Boyd's success:

She was also criticized for hitching her career to that of Gordon Lightfoot at one time. But she says that touring across the U.S. with Lightfoot for two years did a lot towards bringing in a totally new audience. and she doesn't believe it lost her many of her classical fans. "There was no way I could have played to 20,000 people a night on my own." Boyd believes the guitar has served as a bridge to classical music for a lot of young people.2

Boyd has certainly succeeded in bridging this gap between the two genres of music. She has introduced the classical guitar to many who would never have otherwise heard the instrument. Boyd also plays the sort of music the pliblic wants to hear, and not the avante-garde compositions

\footnotetext{
audrey Ashley, "Boyd: Bridging the Pop-Classical Gap." The Ottawa Citizen. 27 April 1984, p.67.
} 
which demand much from the listener. Just as Segovia introduced the classical guitar into the concert hall, Boyd has introduced the classical guitar to the maseses, attacking the elitigm surrounding the instrument within the formal music world.

Many object to Boyd's tactics, yet there are few other musicians able to fill the Roy Thompson Hall to capacity two nights in a row. She has had great success in bringing the classical guitar to new audiences around the world, which in turn has created a larger audience for the more "competent" players to which Tom and Mary Anne Evans were referring. 
TABLE VI: 1

FORYER TEACHERS OF CANADIAN GUITARISTS

NANE OF TEACHER

COUNTRY NUMBER OF GUITARISTS

LESSONS MASTER CLASSES

Eli Kassner

Canada

8

Caról Van Feggelen

Canada

5

Stephen Fentok

Canada

2

Norbert Kraft

Canada

3

1

Mario Levesque

Canada

2

Other

Canada

6

Alice Artz

USA

1

4

Manuel Barrueco

USA

2

Sharon Isbin

USA

1

Aaron Shearer

USA

Rolando Valdes

USA

1

Jul ian Bream

England

:

4

John Mills

Eng $l$ and

2

1

Alirio Diaz

Spain

3

3

Andrés Segovia

Spain

3

Jose Tomas

Spain

2

2

Narcisco Yepes

Spain

1

Alexander Lagoya

France

7

5

Oscar Ghiglia

Italy

3

3

Emilio Pujol

Italy

1

Leo Brouwer

Cuba

Turibio Santos

Brazil

2

Other

Europe

7

2 
Table VI:1 lists the guitarists surveyed and treir influences through former guitar isachers. The two major Canadian teachers were Eli Kassner and Caról Van Feggelen, followed by Norbert Kraft, Marie Levesque, and Stephen Fentok. Without exception, every guitarist had taken part in at least one master class with an international guitarist. Most did not have to leave Canada to do this, as master classes and private tuition by prominent guitarists were offered at music schools, festivals or camps such as Banff School of Fine Arts, Stratford Music Festival, Mount Orford Arts Centre sponsored by Jeunesses Musicales du Canada, and the Toronto guitar festivals. Many of the guitarists went to Europe to further their studies with an international performer after attending master classes in Canada .

With the high level of guitar instruction available in Canada today by teashers who have studied with many of the world's top guitarists, it is interesting to note the importance placed on master classes and private study with internationa! guitarists. Participation in these classes and further private study with an international guitarist is important to aspiring young Canadian guitarists for several reasons. Master classes give the guitarist exposure to both the guitarist conducting the class and members of the audience. The student gains confidence and experience performing under very difficult circumstances and receives 
valuable criticism on her/his playing. It is also very useful to a guitarist to have an impressive list of past teachers on her/his curriculum vitae. 
TABLE VI: 2

MAJOR COMPETITIONS

NAME OF GUITARIST

COMPETITION

Norbert Kraft

1985 Segovia Competition, Spain First Prize 1979 CBC Radio Competition

Grand Prize Winner

Wiiliam Beauvais

1980 Concours de Carrefour Mondiale de la Guitare, Martinique

First Prize

1980 Canadian Music Competition

First Prize

Dale Kavanagh

Scandanavian Guitar Competition

First Prize and Special

Neuchatel Guitrir Competition. Swit.

Second Prize

Segovia Competition, Spain

Third Prize

Gargnano International, Italy

Third Prize

Douglas Reach

1982 International Competition of Guitar Foundation of America

First prize

Richard Bradley

1986 Guitar Canada Competition First Prize

Phillip Candelaria

1980 USA Music Teachers National Assoc. Collegiate Artist Competition First Prize

1976, 1979 Canadian Music Competition Firat Prize

Alvaro Pierri

Premier Prix et Medaille d'Or du Jury Concours International de Paris Porto Allegre \& Buenos Aires Competitions - First Prize 
A list of Canadian guitarists who have placed in the top three places in national and international competitions is found in Table VI:2. Winning a top prize at a competition, especially an international competition, can certainly help a guitarist start a performing career. There are, however, many other guitarists in Canada who perforn extensively both internationally and within this country.

Table VI:3 lists those Canadian guitarists who have recorded at least one album. The list indicates a growing number of guitarists recording albums in Canada. The Encyclopedia of Music in Canada named eight recording artists in its 1981 edition. This number has grown considerably since that time, and many of the original eight artists have released further albums. The Canadian content of these albums will be discussed further in section III of this chapter.

Of the surveyed guitar performers in Canada today, most have performed internationally. Four have played in London's Wigmore Hall, and two in New York's Carnegie Hall. Michael Lauke was the first Canadian guitarist to tour the Soviet Union, and performers such as the Wilson/McAllister duo, the Laval Trio, Liona Boyd, Dale Kavanagh, Norbert Kraft, Alvaro Pierri and Lynne Gangbar have played in most 
countries in Western Europe. Many more guitarists have performed in one or two countries outside Canada.

Through Canadian guitarists winning international competitions and performing in other countries. Canada gains a reputation as a major centre for the classical guitar. Consequently, students of the instrument are attracted to festivals, competitions, summer schools and music faculties in Canada. Some Canadian guitarists, such as Alvaro Pierri, Peter McCutcheon, Norbert Kraft and Paul-André Gagnon, are sought-after teachers and now give master classes at these music schools and festivals. 
TABLE VI: 3

\section{RECORDINGS BY CANADIAN GUITARISTS}

NAME OF GUITARIST

Michael Lauke

Laval Trio

Michael strutt

Peter McCutcheon

Ray Sealey

Alan Rinehart

Bryan Townsend

Dale Kavanagh

Phillip Candelaria

Wilson/McAllister Duo

Norbert Kraft

Davis Joachim

Lynne Gangbar

Liona Boyd

Robert and Sarah

Feuerstein
ALBUM AND CONTENT

Sevr.n albums - solo/ ensemble Mainly Canadian Compositions

Two albums - guitar trio

Two albums

Mainly Canadian Compositions

Two albums

Solo/ Voice and Guitar

Three albums

Voice and Guitar/ Voice, Guitar,

Flute/ 2 Guitars and Narrator

Many original compositions

One album - solo

One album - solo

Some Canadian compositions

One album - solo

One album - solo

Some Canadian compositions

One album - guitar duo

Some Canadian compositions

Five albums - solo/ guitar \& cello/ guitar \& harpsichord/ guitar concertos

Some Canadian compositions

Two a l bums

solo/ Guitar and Flute

Canadian compositions

One album - solo

Fifteen albums - Assorted

Some Canadian compositions

One album - guitar duo 
III

CANADIAN COMPOSITIONS FOR THE CLASSICAL GUITAR

As seen in Table VI:3, the majority of Canadian albums recorded contains some compositions by Canadian composers. Others, such as Michel Cardin's "Atlantic Composers," Michael Strutt's "Komachi." and most of Michael Laucke's albums, are almost entirely devoted to compositions by Canadians.

One major reason for this trend is the availability of funding for the performance of Canadian works. The Canada Council and regional arts councils are more prepared to support an album with these works than one containing only works by non-Canadian composers. The arts councils alsc provide money for works by Canadian composers commissioned by guitarists. Michael Strutt details the breakdown of these commissions in his article. "Canadian Music for Guitar:" :

.. since 1975 almost $\$ 130,000$ has been spent on music for the guitar. The money may only be used to commission Canadian composers, usually through a resident performer, but not exclusively so. In 1982 Jose Evangelista (Montreal) received a commission through Narcisco Yepes. More recently. John Weinzweig (Toronto) has written for the Amsterdam Guitar Trio.... Since 1974 [the Ontario Arts Council] has funded 34 
commissions for a total of $\$ 60,000$, many of these originating with the Guitar Society of Toronto.?

Many of the guitarists surveyed encourage composers in their region to write for the guitar in an attempt to build the small repertoire of the instrument. Consequently, there were a large number of works premiered by and/or written for the guitarists who responded to the questionnaire. In addition, guitarists such as Alan Torok, William Beauvais and Ray Sealey are prolific composers themselves and have written much for the guitar. Alan Torok, for example, has written over two dozen works for the guitar, and has won the Silver Medal for his "Sonata Ritmica" at the 198516 th Annual All Japan Guitar Concours in Tokyo.

Up to now, little of this Canadian music has been included in examination syllabi from music conservatories. Most of the surveyed guitarists wrote that they try to encourage their students to perform works by Canadian composers. Repertoire lists from the conservatories. however, include few Canadian works. The Royal Conservatory of Music Syllabus, for example, contains the following compositions or transcriptions by Canadian composers:

Grade 10 - Alan Torok's "Variations and Fugue on a

"Michael Strutt, "Canadian Music for Guitar." Guitar Canada

3 (Sunmer 1989), P.2. 


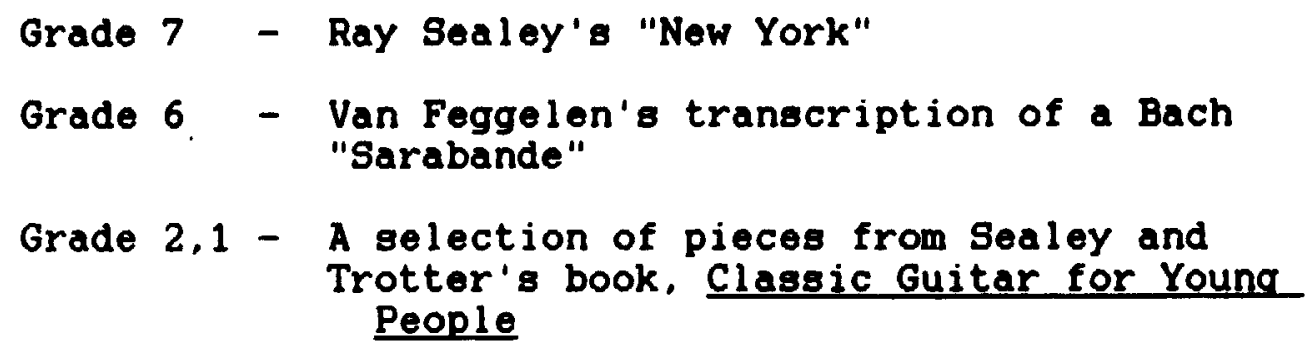
Trotter's book, Classic Guitar for Young People

\begin{abstract}
Since the Royal Conservatory of Music holds examinations across the country. this is a poor representation of works by Canadian composers, given the amount written for the instrument in this country. There is a new syllabus currently being drafted by Norbert Kraft and other conservatory instructors, however, which promises to contain numerous works by Canadians. This is in addition to Kraft's graded series of guitar books.
\end{abstract}


IV

CANADIAN GUITAR MAKERS

Table VI:4 lists the Canadian-made guitars owned by the guitarists surveyed. Several important conclusions regarding the guitar making industry in Canada can be drawn from this information.

Only six of the surveyed guitarists do not own a Canadian-made guitar. The other guitarists own a surprisingly wide selection of guitars, eighteen guitar makers being named representing four provinces. Two of the guitarists, Michael Laucke of Montreal and Michael Strutt of Vancouver, have recorded albums using Canadian-made guitars. In addition, one guitarist owns a lute made by Grant Toml inson of Quebec.

The large number of luthiers indicates a high demand for Canadian hand-crafted guitars today. Since the 1960s when there were only a few makers, the art has blossomed in many of the larger centres such as Vancouver. Toronto and Montreal. Kolya Panhuysen claims that the market for handmade instruments is larger now than it has been at any point 
TABLE VI: 4

CANADIAN MADE GUITARS OWNED BY CANADIAN GUITARISTS

NAME AND CITY OF MAKER

NUMBER OWNED BY GUITARISTS

Richard Berg, Ottawa 2

Sergei de Jong, Toronto 1

Louis Gosselin. Québec 1

Oscar Graph, Ottawa 1

Neil Herbert, Montreal 4

Robert Holroyd, Vancouver (deceased) 2

Gordon Judd, Vancouver 2

Jean-Claude Larrivee, Vancouver 1

William Laskin. Toronto 1

Patt Lister, Stayner 2

Edgar Moench, Toronto (deceased) 1

Fritz Muller, Vancouver 1

Kolya Panhuysen. Toronto 2

Daryl Perry, Winnipeg 2

Mikhail Robert 1

Edward Rusnac, Montreal 1

Rene Wilhelmy. Montreal 2

Daryl Williams, Toronto 3

Own no Canedian-made guitars 6 
during the last ten years.4 This sentiment is echoed by Will iam Laskin, who states:

Within the last two decades, handmaking musical instruments in Toronto has grown into a firmly established and still expanding, small-scale industry. This city is witnessing the irreversible development of a handmade instrument tradition - one that is comprised. I might add, of unusually high standards of work. 8

A number of luthiers such as Panhuysen and Laskin make guitars for Canadians, but also have large European and Japanese markets, 6 where they have gained reputations as builders of fine guitars.

The art of constructing guitars has traditionally been learned through an apprenticeship period with a master builder. In Canada toaay, some makers will take on apprentices. The craft can also be learned at a small number of colleges. A full-time course in guitar making is now offered at Douglas College in British Columbia, instructed by Michael Dunn, who learned the craft from the Ferrer family in Spain.? In September of 1991. George Brown

- Interview with Kolya Panhuysen, Toronto, December 1989.

-William Laskin. The World of Musical Instrument Makers: A Guided Tour (Oakville: Mosaic Press, 1987), p.11.

- Interviews with William Laskin and Kolya Panhuysen. Toronto, December 1989.

TMichael Strutt. "Guitars in the Making," Guitar Canada 1 , No.4 (Spring 1987), p.22. 
College in Toronto will also offer a similar type of programme. Other courses in guitar construction are offered at high schools in Toronto and at the Ontario College of Art.- In this way, the standards of excellence obtained by Canadian guitar makers will be passed on to the next generation of builders.

v

INTERNATIONAL GUITAR FESTIVALS

\section{Guitar ' 75}

At an informal meeting in the fall of 1973, a group of Toronto Guitar Society members discussed the idea of hosting an international guitar festival in Toronto in an attempt to bring together guitarists from around the world. The idea was met with great enthusiasm, and Guitar 75 came into being. John Beckwith, then Dean of Music at the University of Toronto, agreed to have the music faculty co-sponsor the event, and corporate and government financial assistance was obtained.

\footnotetext{
-Laskin. Musical Instrument Makerg. p.11.
} 
Over 480 teachers, -erformers, students and aficionados of the guitar attended the week long festival. An international competition was held, and seven performing artists from around the world were invited to give an evening concert, assist in the adjudication of the festivil. and hold master classes. These artists were Carlos BarbosaLima, Leo Brouwer, John Mills, Oscar Ghiglia, Alirio Diaz and the duo of Ako Ito and Henri Dorigny. Each day various Canadian performers were featured in recitals, displaying Canadian talent. Lynne Gangbar, Danny Beckerman. Alan Torok, Davis Joachim, Ed Honeywell, Harold Micay, Norbert Kraft, Ray Sealey, Peter McCutcheon and Pierre Auge were among these guitarists.

Guitar ' 75 was a tremendous success, leading the way for larger and more ambitious festivals in the years to come. It was the first festival of $i$ ts kind in North America, and has developed into the most important on the continent.

\section{Guitar 78}

Encouraged by the success of Guitar 175, the Toronto Guitar Society planned a second festival. The theme, "Quest for New Music," was established in an attempt to gain a number of fine new works for the guitar's limited repertoire. One of the largest problems with the instrument 
has always been its poor repertoire. Transcriptions of works written for other instruments have helped this situation, but many guitarists from Segovia on have tried to encourage major composers to write for the guitar to develop a quality repertoire of its own.

With this aim in mind, Guitar 78 hosted an international competition for guitar compositions, receiving seventy-five entries from around the world. The jury consisted of Toronto composers Dr. Samuel Dolin and John Weinzweig. Eli Kassner and English composer Stephen Dodgson. The winners had their works premiered during the festival. Among the five winners were Canadians Tomars Dusatko with "Interaction" for guitar and tape, and Douglas Jamieson with "Elegy for Guitar."

Sophocles Papas and Vladimir Bobri, both of the United States. were invited to be the honoured guests of Guitar ' 78 in recognition of their outstanding contributions to the classical guitar. In the programme for the festival, the following message was sritten by Papas:

I congratulate the sponsors of the Guitar '78 for such an important event on behalf of the most beloved instrument of all time - the guitar! This is a great occasion and wonderful upportunity for performers. scholars, students, makers and lovers of the guitar to receive overall inspiration from the events scheduled. It is a special pleasure for me to attend these seminars on the guitar because I have witnessed the birth and growth of the guitar and have dedicated my life toward its enrichment and advancement.. I hope 
Guitar '78, now that it is established in Canada, will become the major event of the North-American continent. 9

Liona Boyd was the evening performer on the first day of the festival, follcied by Leo Brouwer, Carlos Bonell. Turibio Santos and Abel Carlevaro. Each of these guitarists premiered a work commissioned by the Toronto Guitar Society. Brouwer, a proliaic composer for the guitar himself, premiered John Weinzweig's "Contrasts."

"Nobody is perfect and no instrument is perfect either," says Brouwer. "I wish the guitar had more high pitches. And I wish we had more repertoire from the Romantic period. But composers are finding many ways to develop the instrument sti!l further. I am very interested in what John Weinzweig has written in his "Contrasts."10

Weinzweig's piece was one of many quality works for the guitar to come out of these Toror.to festivals.

\section{Guitar ' 81}

Guitar ' 81 coincided with the 25 th anniversary of the formation of the Toronto Guitar Society. In addition to the theme of "Quest for New Music." the themes "teaching the guitar" and "the guitar in ensemble" were added.

\footnotetext{
- Gujtar 78 Programme, June 1978, GSTA, p.1.

10 William Littler. "Toronto Hails the Guitar Instrument of the Century." Toronto Star 17 June 1978, p.E4.
} 
Consequertly, the new music competition included entries for solo guitar pieces at beginner, intermediate and advanced levels of difficulty, and guitar duets or trios at various levels of difficulty. Over 120 entries were received, of which twelve composers were selected to receive commissions for new works. A total value of over $\$ 10,000$ was awarded for these commissions. Winning Canadian composers were John Armstrong, John Burke, Stephen Chatman, Harry Freedman, Anthony Genge and Lothar Klein.

Evening concerts at the festival featured John Mills. Sergio Abreu. Sharon Isbin. Narciso Yepes, Turibio Santos, and lutenists Paul O'Dette and Toyohiko Satoh. Toronto's Lynne Gangbar appeared with John Mills in a duet performance, having studied with him while persuing her ARCM from the Royal College of Music in London. The Canadian Showcase series included soloists Michael Strutt, Peter McCutcheon, Alan Torok. Phillip Candelaria and Gordon 0 'Brien, and in keeping with the "guitar in ensemble" theme. the Laval Trio, the Wilson/McAllister Duo, Tom and Lynn West, Robert and Sarah Feverstein. Norbert Kraft and Bonnie Silver, and Ray Sealey with his own composition for two young guitarists and narrator. 
Guitar' 84

Held during celebrations of Toronto's 150th anniversary and Ontario's 200th anniversary. Guitar ' 84 proved to be even more ambitious than the first three festivals. It was extended three days in length, and its thene was the "Guitar Concerto." Four guitar concertos were commissioned and premiered at the festival: "Concerto *3" by Leo Brouwer (Cuba). "Concerto Grosso for Guitar and String Orchestra" by Stephen Dodgson (England). Concerto \#3 by Guido Santorsola (Uruguay), and "Concerto *1" by Harry Somers (Canada). The Wilson/McAllister duo also premiered a concerto dedicated to them by Italian composer Sergio Chieeghin.

New developments in the festi:al included the inclusion of jazz guitar. A "Greats of Jazz" concert was held in conjunction with the month-long anniversary festivities in Toronto. This concert featured Ed Bickert. Charlie Byrd. Herb Ellis, Marty Grosz and Barney Kessel.

The Guitar' 84 also sponsored the first international lute competition ever held. Thirty entries were received from six countries. Prize money for the guitar competition was increased, and the festival received eighty entries from thirteen countries. 
Guitar ' 87

This was the last guitar festival held in Toronto to date, Guitar ' 90 being cancelled for financial reasons. Guitar '87 lost over $\$ 55,000$, which will obviously cause future committees for the event to make major changes. Until the Guitar ' 87 festival, the organization of these events was done by volunteers, largely the work of Joan York. A salary was paid to two organizers for the Guitar ' 87 festival, and it was approximately this amount of money the festival was in debt.

There were fifteen premiere performances in the seven days of the festival, bringing the total number of commissioned works by the Toronto guitar festivals to thirty-seven. Norbert Kraft premiered Canada's R. Murray Schafer's first work for the guitar. "Le Cri de Merlin." and John Williams played Brouwer's "Toronto Concerto," a piece written for and dedicated to Williams.

The five guitar festivals Toronto has hosted have resulted in international recognition of guitar activities in this country. Canadian compositions and performers from across the country have been featured in each of the festivals, and makers have had the opportunity to display their instruments. Although obviously centred around guitarists in the Toronto region, the festivals have 
achieved some unity among guitarists, not only in various parts of the world, but among the many widespread regions within Canada.

VI

GUITAR COMPETITIONS

After the success of the international competitions held every three years at the Toronto guitar festivals, it was decided to hold a national competition every three years as well. with different cities in the country hosting the event. This was in addition to the annual Guitar Society of Toronto competitions for residents of Ontario already in existence. The result is that each year there is a rotation of competitions.

The first "Guitar Canada" rational competition was held in Toronto in 1986, presented by the Guitar Society of Toronto. Composer John Armstrong was commissioned to write a work for guitar and chamber orchestra which was a required prece for each of the five finalists. Richard Bradley of Toronto won the competition, a concert at Guitar ' 87 being one of the prizes. A large percentage of the funding for 
this competition came from government funding, both provincial and federal.

Guitar Canada 1939 was held in Ottawa and was the first fully bilingual competition in Canada. Steven Gellman, an Ottawa composer, was commissioned to write the piece for the finalists, which he scored for guitar and string quartet. Patrick Rioux, instructor at the "Conservatoire de Musique à Hull." came first in the competition. As in the first Guitar Canada, the adjudicators were prominent guitarists representing most regions of the country. and funding, although greatly reduced, was assisted by the government.

The 1989 national competition, like its predecessor. did much to promote a unity among classical guitarists across the country. Holding it in a centre other than Toronto took the focus off a city which has done so much for the guitar in Canada, but which is not the only city in which the guitar is popular. The bilingual aspect helped to erode some of the barriers between French and English Canadian guitarists. Indeed, the guest performer. Alvaro Pierri, guitar instructor at McGill University, had never before played in English Canada although he has toured extensively in many other parts of the world. The French and English divisions will be further explored in the conclusion to this chapter. 
VII

CONCLUSION

This chapter has explored the last two decades of classical guitar activity in Canada, and has argued that they have been years of numerous achievements by teachers, performers, composers and makers of the instrument. Their efforts have elevated the status of the instrument across the country and have brought international recognition to Canada. The availability of government funding, the increased number and quality of guitar programmes in universities and conservatories, the interest taken in the instrument by Canadian composers, and the opfortunities for students to study with some of the world's finest guitarists in Canadian music schools and festivals have all contributed to the success of the classical guitar in Canada.

Grants from the Canada Council and regional arts councils have enabled guitarists to pursue advanced study of the instrument in other countries or commission Canadian composers to write for the instrument. Some performers such as the Wilson/McAllister duo have received grants to support concert tours in other countries. Michael Strutt received funds from the Department of External Affairs to play a concert tour in Poland. Most guitar festivals and 
competitions would not have been possible without government assistance of some kind. Government grants have played an important role in contributing to the education and promotion of many Canadian guitarists, composers. competitions and festivals. Unfortunately, a detailed list of societies, guitarists, and composers who have received grants was not available for this study.

The large interest shown by Canadian composers in writing for the classical guitar has resulted in a number of exceptional works being created. Many of the country's best-known composers have now written for the instrument. Norbert Kraft, for example, has just released recordings of R. Murray Schafer's Guitar Concerto and "Le Cri de Merlin." both of which he commissioned. Composers such as Schafer are exploring new possibilities of the instrument, and as a result their compositions are receiving interest from guitarists from other countries, such as Leo Brouwer's praise of John Weinzweig's "Contrasts," and Julian Bream's recommendation of Harry Somers' "Sonata for Guitar" to students at the Stratford master classes.11

As discussed previously, there is government suppor: available for the ccmmissioning and performance of works by Canadian composers. This has resulted in many guitarists and Lute 24 (September 1982), p.35. 
encouraging composers in their regions of the country to write for the instrument.

\begin{abstract}
Davis Joachim [son of composer Otto Joachim] was probably the first Canadian classical guitarist to discover that money was available for both the commissioning and recording of new Canadian works. Guitarists found they could compete with other instrumentalists for access to this money. There were also open doors at the $\mathrm{CBC}^{\prime} s$ new music programs.

"Playing Canadian repertoire was good business." Davis Joachim admits.12
\end{abstract}

The large number of Canadian guitarists who have included Canadian compositions in their recordings (see table VI:3) supports Joachim's statement.

Over the last two decades, the issue of playing of the right- or left-hand side of the nail appears to have become less important. Most guitarists are now aware of both techniques and choose that which enables them to obtain the best results. Provincial and national festivals, summer music schools and bilingual national competitions seem to be helping to slowly erode the barriers between French and English guitarists and establish some sort of unity between classical guitarists across the country.

Much of the unity between classical guitarists in various regions of the country is provided through guitar

\footnotetext{
${ }^{12}$ Alan Torok. "A Short History of Classical Guitar in Canada." Music Scene (May/June 1984), p.5.
} 
TABLE VI : 5

GUITAR SOCIETIES IN CANADA

\begin{tabular}{|c|c|c|c|c|}
\hline NAME OF SOCIETY & YEAR STARTED & \multicolumn{2}{|c|}{ YEAR ENDED } & $\begin{array}{l}\text { NUMBER } 0 \\
\text { MEMBERS }\end{array}$ \\
\hline Edmonton G.S. & $1960 \mathrm{~s}$ & & $?$ & - \\
\hline Halifax G.S. & 1975 & & 1980 & - \\
\hline Hamilton G.S. & 1989 & In & existence & 50 \\
\hline Kingston G.S. & $?$ & In & existence & $?$ \\
\hline Lethbridge G.S. & 1990 & In & existence & $?$ \\
\hline London G.S. & $1970 \mathrm{~s}$ & & $1980 \mathrm{~s}$ & - \\
\hline Montreal G.S. & 1953 & & 1953 & - \\
\hline & 1976 & & 1978 & - \\
\hline Ottawa G.S. & 1969 & In & existence & 60 \\
\hline Sault Ste. Marie G.S. & $?$ & In & existence & $?$ \\
\hline Thunder Bay G.S. & 1980 & & $1980 \mathrm{~s}$ & - \\
\hline Toronto G.S. & 1956 & In & existence & 250 \\
\hline Vancouver G.S. & 1967 & In & existence & 100 \\
\hline Winnipeg G.S. & 1984 & In & existence & 50 \\
\hline
\end{tabular}


societies. Table VI:5 lists the known guitar societies which are or have been in existence in Canada over the last three decades, as determined by the questionnaires.

The results show that eight guitar societies are currently operating at this time across the country, and another five societies have been formed in the past. but are now defunct. As societies are volunteer organizations, the administrative duties necessary to keep a society together generally depend on the time donated by members. The ottawa Society. for example. has been a strong society for so many years largely due to the efforts of Ed Honeywell. The second formation of the Montreal Society failed when Michael Strutt could no longer devote enough time to keeping the society going.

The presence of so many societies across Canada disputes the Encyclopedia of Music in Canada's sta:ement, "Guitar societies have been established in Edmonton. Ottawa and Toronto."13 It is interesting to note the lack of societies in French Canada. Two societies have been started in Montreal. both by English-speaking guitarists, but there has never been a society in Quebec City or other French

\footnotetext{
${ }^{23}$ Helmut Kallmann et al, eds., "Guitar." Encyclopedia of Music in Canada (Toronto: University of Toronto Press. 1981). p.398.
} 
areas of the country. Perhaps this could be the topic of a future study.

Certainly the most important guitar society in Canada is the Guitar Society of Toronto. Since its earliest years, it has contributed a tremendous amount to the development of the classical guitar in Canada. From its international guitar festivals featuring world class performers to the scholarships and competitions offered to students of the society. Toronto's guitar society has done much toward bringing international recognition to Canadian teachers. performers, makers and composers of the classical guitar. 


\section{CHAPTER SEVEN}

CONCLUSION

In this thesis. I have attempted to demonstrate that the guitar has been in existence in Canada since the days of the first European settlers, and that it was a popular instrument in early pioneer societies. With the rise of the classical guitar around the world in the twentieth century. I have tried to show that Canada has developed into a world class centre for the classical guitar. making significant contributions.

The large number of references to the guitar being sold, taught and performed in Canada during the eighteenth and nineteenth centuries clearly supports the argument that the instrument was popular with early settlers in the country. An analysis of these references also gives an indication of the sort of music played and by whom, and the countries in which the instruments and strings were made. This information led to my conclusion that the guitar was influenced by European trends until the mid-nineteenth century. After that time, the guitar was rarely played in Europe, and consequently instruments and music were purcnased from the United States. This resulted in the transplantation of the American popular cuiture of the day. 
shown in the popularity of guitar, banjo and mandol in groups in mogt of the major centres across Canada.

An analysis of the early references to the guitar in Canada also indicates the instrument was predominately a middle class woman's instrument. Middle class women could afford the luxury of music lessons and instruments, but in many cases could not af', rd the more prestigious pianoforte. Women were discouraged from performing in public and teaching. however, so the majority of guitar teachers and performers were men.

The twentieth century saw the establishment of numerous styles of guitar playing. As the popularity of the classical guitar led to its acceptance in concert hal is and music faculties and conservatories across Canada, divisions developed between the classical guitar and other styles of guitar performance.

To play the classical guitar well was (and is) to devote many years to its study in a technically formal manner. This, plus the musical aesthetics of the classical style, widened the gap between serious students of the instrument and those who played in a "rock" or other popular sort of band. The classical guitar was performed in recital halls subject to all the unwritten rules of etiquette associated with art music performances, such as dress and 
applause at the correct moments. In a sense, the classical guitar bacame an elitist instrument. This is reflected in the manner in which many guitar societies refused to allow performances of other styles of guitar during their meetings.

Within the classical guitar circle itself in Canada there were other divisions. Playing with the left or the right side of the right hand nails became a large issue. each school claiming theirs was the "better method." It was certainly the topic of much debate and tension. especially between Ontario and Quebec due to their close proximity. As discussed in chapter six. this division seems to be gradually disappearing, with guitarists using the technique best-suited to their hands.

Before Liona Boyd left a career in classical guitar performance, she was able to erode the elitism witlin the world of guitar. By performing as an opening act for folk singer Gordon Lightfoot to audiences of over 20,000 in stadiums, she did much to bring the classical guitar from its limited audience to the masses. Even the Canadian compositions she commissioned, such as Milton Barne's "Fantasy for Guitar." are very melodic and easy for the unec lcated listener to absorb. 
Other Canadian classical guitarists have tried to capture some of this market through their selection of repertoire. Toronto's John Perrone plays light classics on the guitar with a string orchestral background. The Wilson/McAllister duo released an album with a recording of Don Wilson's "Bluegrass" tune, and Norbert Kraft has recorded an album of popular classics with cellist ofra Harnoy. No other Canadian classical guitarist, however, has yet managed to capture the market in the same manner as Liona Boyd.

The majority of Canadian classical guitarists with recordings are appealing to an extremely small percentage of the country's population. Many play contemporary compositions by Canadian composers, and while the result is often very fine albums, their public appeal is limited. It has been estimated that less than one percent of the taxpaying population appreciates contemporary music.1 This is unfortunate for classical guitarists, as much of their repertoire is from the twentieth century due to the limited number of composers writing for the instrument before that time.

Today, the classical guitar remains a very popular instrument in educational institutions across the country.

\footnotetext{
${ }^{1}$ Michael Strutt. "Canadian Music for Guitar." Guitar Canada (Summer 1989). p.3.
} 
Newfoundland is the only province that does not offer the opportunity of specializing in the classical guitar in a music degree, although the instrument is gaining public interest through music festivals and competitions held across that province. A number of music faculties, such as McGill University. the University of British Columbia, the University of Toronto and the University of Western Ontario, now offer a Master's degree in performance on the classical guitar, making it possible for students to obtain a high level of training on the instrument without having to leave the country.

It is interesting to note the ratio of male and female classical guitarists holding prominent positions in universities and conservatories across the country today. As seen in chapters two and three of this study, the guitar was always considered to be a woman's instrument during the eighteenth and nineteenth centuries, although performed and taught by men. Of the fifty classical guitarists surveyed, only four are women, or less than ten percert. Liona Boyd seems to represent what the guitar was in early Canada: an instrumert adopted by immigrant women to play light tunes as a means of entertainment in the early pioneer homes. Unfortunately, the current ratio of male and female students at conservatories and universities is not known, but the classical guitar in Canada appears to be more a man's instrument. 
Carl Morey, the Dean of Music at the Universicy of Toronto, was asked to comment on the current status of the guitar at that university:

It has a stable place. But it does not have the status of the piano as a solo instrument. It obviously does not have the place of chamber music instruments. It really exists as a highl; specialized, although very, very popular solo instrument. It would be an easy instrument to omit from the faculty. and the faculty would not suffer for this. Our orchestras would continue to function, we'd still produce teachers and performers for the general music life, but I don't think it would ever enter anyone's mind at this point to drop the guitar. The guitar has become a legitimate instrument at the University of Toronto. 2

The entire history of the guitar in Canada has been one of influences from other countries. Until the midnineteenth century. European countries dictated the instruments, music and social status of the guitar in Canada through the desire of immigraints to transplant the culture of their old country. American music and instruments had an impact on Canadian guitarists after that time, shown in the rise of guitar, mandolin and banjo groups and the American music written for these combinations.

The early classical guitar in Canada was largely influenced by Andrés Segovia through his concerts. recordings and master classes. Most Canadian guitarists

\footnotetext{
"Harold J. L.evy, "The Road to Respect." "Tribute to Eli Kassner" GSTA (27 May 1989), p.7.
} 
studied abroad and played Europeari-made instruments. Over the last twenty years. however, the efforts of Stephen Fentok, El i Kassner. Caról Van Feggelen and many others to build the status of the classical guitar in Canada have been successful. As this thesis has attempted to prove, the guitar has gained acceptance and legitimacy across the country and Canada has become an important centre in the classical guitar world, able to influence other countries.

The achievements of Canadians in this field are considerable. Canadian performers are now winning prestigious international competitions and performing around the worid. Compositions by Canadian composers are receiving recognition from world-class guitarists and Canadian guital makers have estatlished large European and Japanese markets for their instruments. Many guitar students from other countries now come to study with some of Canada's more prominent teachers. Finally, the Guitar Society of Toronto's international festivals and competitions are still among the most important in the world.

This is the first study of its kind in Canada, and has attempted to unify over three hundred years of history across a very large country with many distinct regions and people. Due to the magnitude of $t_{1}, 3$ undertaking. therefore, there is much room for further study. 
Financial and time limitations made it impossible to visit each of the provinces in Canada to do a more complete history of each area. While a majority of the guitariata across the country responded to my inquiries of the status of the guitar in their area. and their contributions and achievements in the field of the classical guitar in Canada. there are obvious gaps where there was no response. Finally. since much of the later information was in the form of an oral history, there are possibilities of discrepancies and inaccuracies where memory failed or one became too subjective.

There are many who have contributed to Canada's development as a strong classical guitar centre. Unfortunately, it was not possible in this study to acknowledge all of these people, or list each individual's achievements. Perhaps tinis wll be possible in future studies. 
APPENDIX

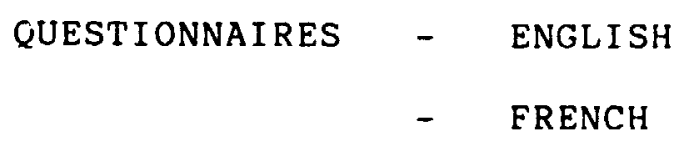


QUESTIONNAIRE

NAME :

ADDRESS :

1. At which music school do you teach?

For how long?

Current number of students?

How long has guitar instruction been offered at this institution?

2. Is there a guitar society in your area?

Name of society?

How old is it?

Approximate membership?

3. Do you own a Canadian-made guitrr? If so, who is the maker?

4. What is your musical background? Where and with whom did you study the guitar? 
5. Please outline your performing experience. Include any concerts you have performed outside of Canada.

6. Have you ever performed a work by a Canadian composer? If so, please give details.

7. What do you feel have been your personal contributions to the guitar in Canada? Include details such as teaching, recordings, compositions, transcriptions, adjudication, premiere performances, etc. Use the back of the paper if necessary. 
Nom:

Adresse:

1. A quelle école de musique enseignez-vous?

Depuis combien de temps?

Votre nombre actuel d'étuaiant?

Depuis combien de temps est-ce que l'enseignement de la guitare est of zert dans votre institution?

Avez-vous un ensemble de guitare?

2. Ya-t-il une association de guitaristes dans votre région?

Quel est son nom?

Quel âge a-t-elle?

Nombre approximatif des membres?

Combien de récitals de guitare sont donnés dans votre région par année?

Attirent-ils beaucoup de monde?

3. Possédez-vous une guitare fabriquée au Canada? Si oui, quel est le fabriquant?

4. Quel est votre histoire musicale? Où et avec qui avez-vous étudié la guitare? 
5. S'il-vous-plait décrire votre expérience d'exécutant, incluant vos concerts à l'extérieur du Canada.

6. Avez-vous déjà interprété une oeuvre canacienne? Si oui, donnez des détails.

7. Que pensez-vous a été votre contribution personnelie a domaine de la guitare au Canada? Donnez des détails comme l'enseignement, les enregistrements, la composition, la transcription, les jugements aux competitions, les premières, etc. Utilisez le verso si nécessaire. 


\section{BIBLIOGRAPHY}

Amtmann. Willy. Music in Canada 1600-1800. Québec: Habitex Books, 1975.

. La Musique au Québec 1600-1875. Montréal: Les Editions de l'Homme, 1976.

Ashley, Audrey. "Boyd: Bridging the Pop-Classical Gap." Ottawo Citizen. 27 April 1984, p.67.

Bellow, Alexander. The Illustrated History of the Guitar. New York: Belwin Mills, 1970.

Blakeley, Phyllis R. "Music in Nova Scotia 1605-1867." The Dalhousie Review 31 (Surmer/Autumn 1951).

Bone, Phillip J. The Guitar and Mandolin: Biographies of Celebrated Players. London: Schott, 1972.

Bonfield, John. "Bertram Atkins." National Archives of Canada, Music Division, n.d.

"Braune is, Jean-Chrysotome." Encyclopedia of Music in Canada. Toronto: University of Toronto Press, 1981.

Calderisi. Maria. Music Publishing in the Canadas 18001867. Ottawa: National Library of Canada, 1981.

Canadian Musicial Review I:1 (1 May 1856).

The Colonist. (Vancouver) 2 November 1902, p.3.

Corbett. Edward A. We have With Us Tonight. Toronto: Ryerson Press, 1957.

Danner. Peter. "Guitar in 19th Century America: A Lost Social Tradition." Soundboard (Fall 1985). "Guitar." The New Grove Directory of American Music Vol.2. London: MacMillan Press, 1986.

Dunae, Patrick A. Gentlemen Emigrants Vancouver: Douglas \& McIntyre, 1981.

Edmonton Bulletin. 16 July 1896 - 3 March 1898. 
Evans, Tom and Mary Anne. Guitar: From the Renaissance to Rock. New York: Paddington Press. 1977.

Evening Mercury. (Guelph) 17 January 1894 - 24 March 1894.

Fentok, Stephen. Personal Interview, Montreal. October 1989.

Ford, Clifford. Canada's Music: An Historical Survey.

Agincourt: GLC Publ., 1982.

Foussard. Michel (ed.). Guitares. Paris: La Flûte de Pan. 1980 .

"Gay. Frank." Encyclopedia of Music in Canada. Toronto: University of Toronto Press, 1981.

La Gazette de Montréal. 23 February 1786, p.2.

Gillard, Cheryl A. "Women in Music in Canada: An Introduction." Unpublished MA Thesis, Institute of Canadian Studies, Carleton University. 1987.

Globe and Mail. 14 August 1851, p.2.

Grunfield. Frederic V. The Art and Times of the Guitar.

Toronto: Collier-MacMillan Canada, 1969.

"Guitar." Encyclopedia of Music in Canada. Toronto"

University of Toronto Press, 1981.

Guitar Society of Toronto Archives, Toronto. "Bulletins" and letters from 1956-1989.

"Guitars Gain Fame for Quality Work." The Star Phoenix (Saskatoon). 27 June i973, p.47.

Hal1. Frederick A. The Canadian Musical Heritage: Songs I ottawa. 1985.

" Musical Life in 18th Century Halifax." Canadian University Music Review 4 (1983).

Harper, J. Russell. Painting in Canada: A History.

Toronto: University of Toronto Press, 1966.

"Jordan. Robert Christopher." Encyclopedia of Music in

Canada. Toronto:University of Toronto Press, 1981.

Kallmann, Heimut. A Short Histoiy of Music in Canada 15341914. Toronto: University of Toronto Press, 1981.

et al (eds.). Encyclopedia of Music in Canada.

Toronto: University of Toronto Press. 1981. 
"Guitar." The Canadian Encyclopedia. 2nd ed.

Edmoncon: Hurtig Publ., 1988.

"Music History." The Canadian Encyclopedia. 2nd ed. Edmonton: Hurtig Publ., 1988.

Kassner, Eli, "The Guitar Society of Toronto." In "Tribute to Eli Kassner. "Guitar Society of Toronto. 27 May 1989 .

- Personal Interview, Toronto. March 1988.

Kozinn, Allan. The Guitar: The History, The Music, The

Players. Toronto: Musson-General, 1984.

Laskin, William. The World of Instrument Makers: A Guided Tour. Oakville: Mosaic Press, 1987.

- Personal Interview, Toronto. December. 1989.

Lauke, Michael. "Growth of the Guitar in Canada." Guitar and Lute. (Sept. 1982 and Nov. 1982).

Levy, Harold. "The Road to Respect." from "Tribute to Eli Kassner." Guitar Society of Toronto. 27 May 1989.

Littler. William. "Toronto Hails the cuitar as Instrument of the Century." Toronto Star. 17 June 1978, p.E4.

Marunchak, Michael H. The Ukrainiens Canadians: A History. Winnipeg: Ukrainian Free Academy of Sciences, 1970.

McIntosh. Robert Dale. A Documentary History of Music in Victoria. Volume I : 1850-1899. Victoria: University of Victoria Press, 1981.

McMillan, Barclay. "Music in Canada 1791-1867: A Travel lers' Perspective." Unpublished MA Thesis. Institute of Canadian Studies, Carleton University, 1983.

Montreal City Directory. Montreal, 1847.

Muir, R.T. Cataloque of Sheet Music and Music Books For Sale in Halifax. Halifax. 1869.

Music Journal II: 9 (November 1988), p.34.

Musical Redbook of Montreal. Montreal, 1896. p.150.

"Musique." Le Canada Musical 2:8 (1 December 1875).

National Archives of Canada. Music Division. Concert Programmes. 

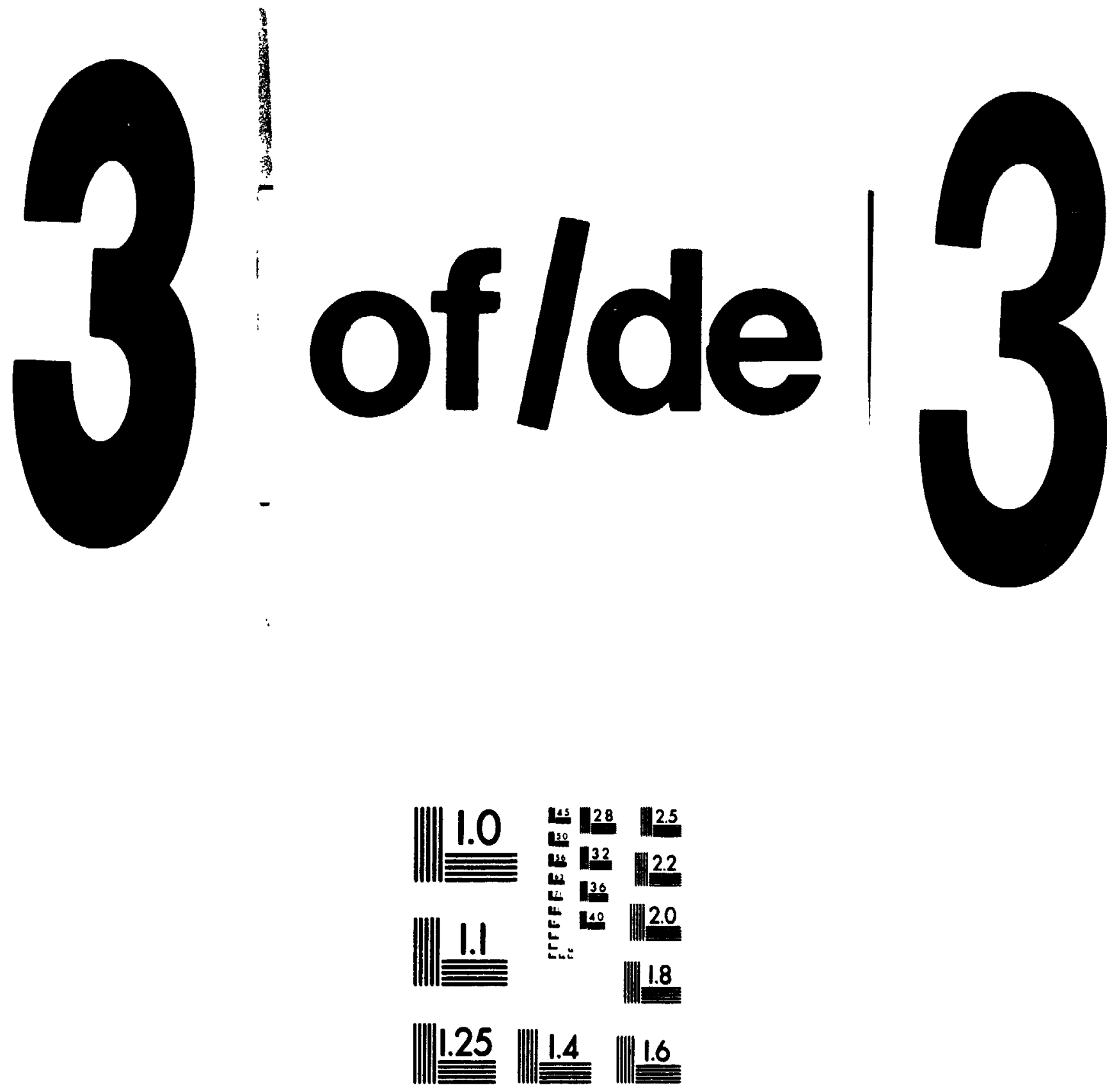

MICROCOPY RESOLUTION TEST CHART

NATIONAL BUREAU OF STANDAROS

STANOARO REFERENCE MATERIAL $1010 \mathrm{a}$

(ANSI and ISO TEST CHAAT NO 2) 
Panhuysen, Kolya. Personal Interview, Toronto. December, 1989.

Ottawa City Directory. Ottawa, 1869-77.

Québec and Levis Directory. Québec, 1872-1875.

Québec Herald. 15 June 1789, p.201.

Society of the Classic Guitar. New York. Guitar Review. 1-3 (1946-1955).

Smith, Harold. "Eli Kassner: A Biography." from "Tribute to Eli Kassnsr." Guitar Society of Toronto. 27 May 1989.

Spaeth, Sigmund. History of Popular Music in America. New York: Random House, 1948.

Strutt. Michael. "Canadian Music for Guitar." Guitar Canada. (May/June 1984). $\overline{1987)}$.

"Guitars in the Making." Guitar Canada 1:4. (Spring

Summerfield. Maurice J. The Classical Guitar: Its Evolution and Its Players Since 1800. Great Britain: Ashley Mark Press, 1982 .

Thomson, Hugh. "Edgar Moench: The Stradivarius of Guitarmakers." Globe and Mail. 25 June 1966. p.14. "Guitar Maker Patt Lieter Keeps on Trying for Periection." Globe and Mail. 2 August 1974, p.10.

Torok, Alan. "A Short History of Classical Guitar in Canada." Music Scene. (May/June 1984).

Toronto City Directory. Toronto. 1862-63.

Turnbul1. Harvey. The Guitar: From the Renaissance to the Present Day. London: Batsford Press, 1974.

Van Feggelen, Caról. Personal Interview, Halifax, September. 1989.

Wade. Graham. Traditions of the Classical Guitar. London: John Calder Press, 1980.

"Williams, R.S. Sons." Encyclopedia of Music in Canada. Toronto: University of Toronto Press, 1981. 
Woodford, Paul. We Love the Place, o Lord: A History of the Written Musical Tradition of Newfoundland and Labrador to 1949. St. John's: Creative Publ.. 1988.

Yuzyk, Paul. The Ukrainians in Manitoba. Tronto: University of Toronto Press. 1953. 

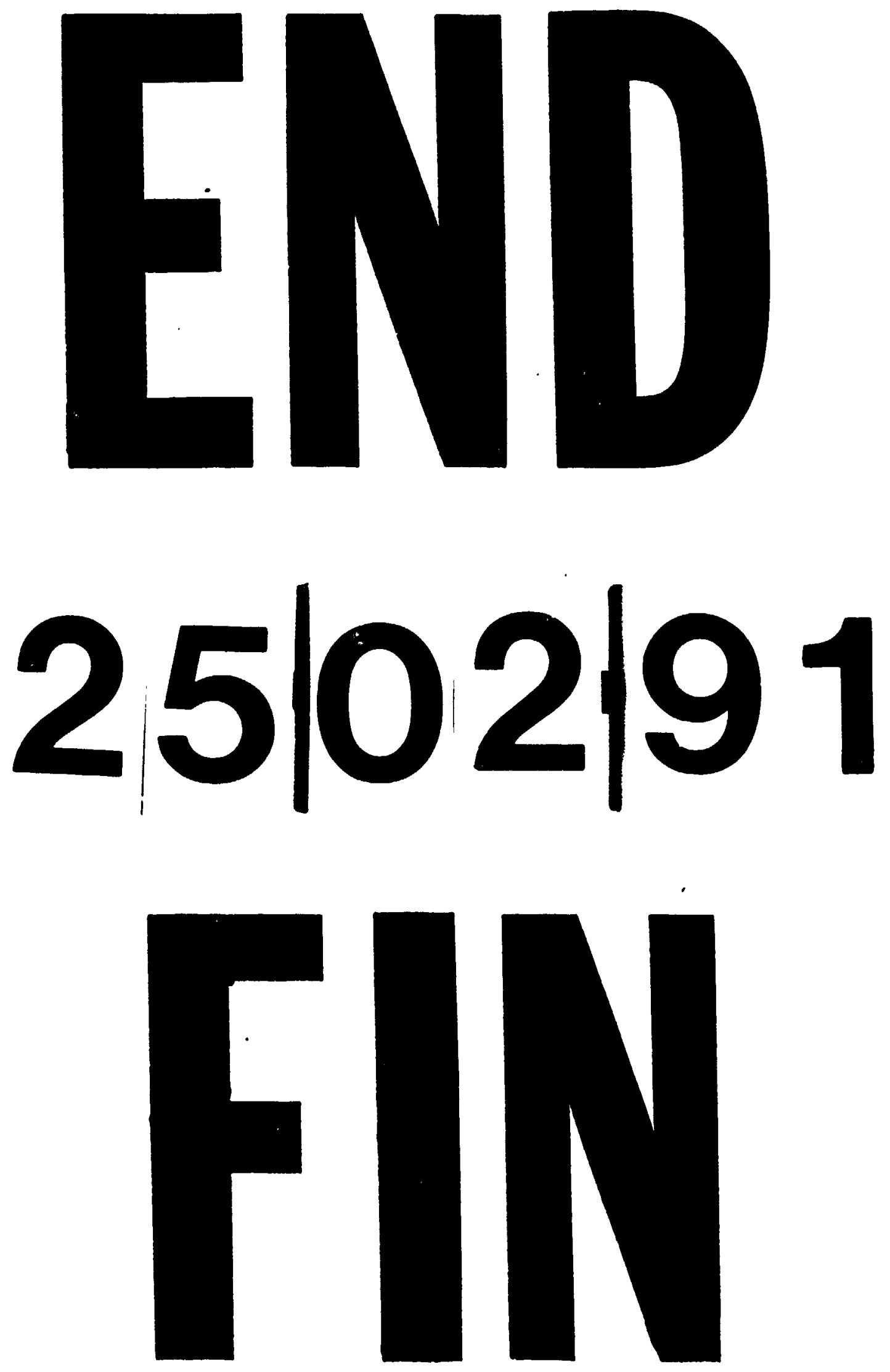